\title{
Direct Evaporative Precooling Model and Analysis
}

Development and Simulations of an Improved Algorithm for Import into EnergyPlus and Applications to Commercial Buildings in the United States

\section{September 2010}

Prepared by

Bo Shen

Moonis R. Ally

C. Keith Rice

William C. Craddick

Building Technologies Research and Integration Center

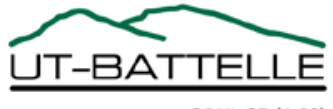




\section{DOCUMENT AVAILABILITY}

Reports produced after January 1, 1996, are generally available free via the U.S. Department of Energy (DOE) Information Bridge.

Web site http://www.osti.gov/bridge

Reports produced before January 1, 1996, may be purchased by members of the public from the following source.

National Technical Information Service

5285 Port Royal Road

Springfield, VA 22161

Telephone 703-605-6000 (1-800-553-6847)

TDD 703-487-4639

Fax 703-605-6900

E-mail info@ntis.gov

Web site http://www.ntis.gov/support/ordernowabout.htm

Reports are available to DOE employees, DOE contractors, Energy Technology Data Exchange (ETDE) representatives, and International Nuclear Information System (INIS) representatives from the following source.

Office of Scientific and Technical Information

P.O. Box 62

Oak Ridge, TN 37831

Telephone 865-576-8401

Fax 865-576-5728

E-mail reports@osti.gov

Web site http://www.osti.gov/contact.html

This report was prepared as an account of work sponsored by an agency of the United States Government. Neither the United States Government nor any agency thereof, nor any of their employees, makes any warranty, express or implied, or assumes any legal liability or responsibility for the accuracy, completeness, or usefulness of any information, apparatus, product, or process disclosed, or represents that its use would not infringe privately owned rights. Reference herein to any specific commercial product, process, or service by trade name, trademark, manufacturer, or otherwise, does not necessarily constitute or imply its endorsement, recommendation, or favoring by the United States Government or any agency thereof. The views and opinions of authors expressed herein do not necessarily state or reflect those of the United States Government or any agency thereof. 


\title{
DIRECT EVAPORATIVE PRECOOLING MODEL AND ANALYSIS
}

\section{Development and Simulations of an Improved Algorithm for Import into EnergyPlus and Applications to Commercial Buildings in the United States}

\author{
Bo Shen \\ Moonis R. Ally \\ C. Keith Rice \\ William C. Craddick
}

Date Published: September 2010

Prepared by

OAK RIDGE NATIONAL LABORATORY

Oak Ridge, Tennessee 37831-6283

managed by

UT-BATTELLE, LLC

for the

U.S. DEPARTMENT OF ENERGY

under contract DE-AC05-00OR22725 



\section{CONTENTS}

Page

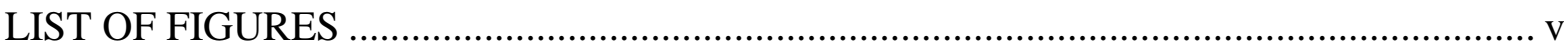

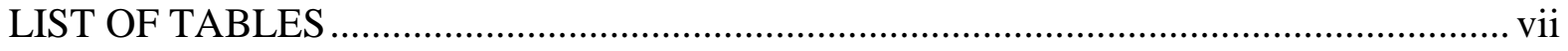

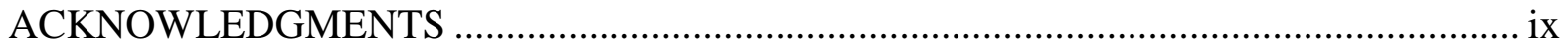

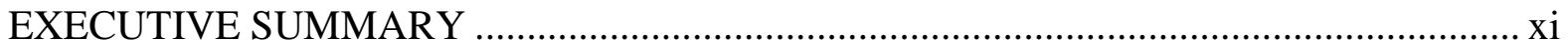

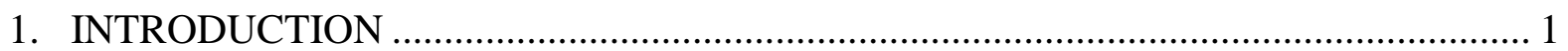

2. PRE-COOLING METHODOLOGY IN ENERGYPLUS............................................. 3

3. ALTERNATE MODEL FOR IMPORTATION INTO ENERGYPLUS ........................ 5

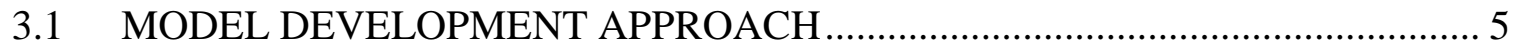

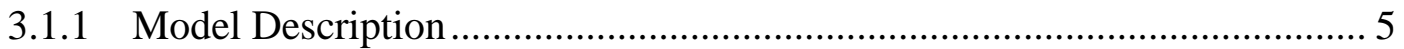

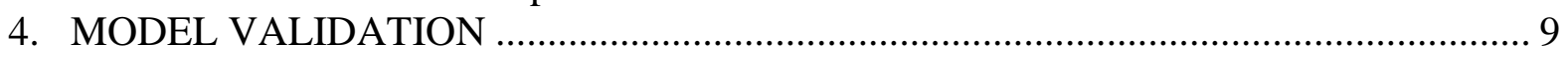

4.1 COMPARISON OF ENERGYPLUS AGAINST ALTERNATIVE METHODOLOGY WITH MANUFACTURER'S DATA.................................... 9

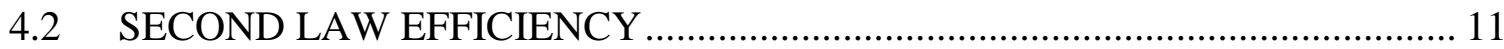

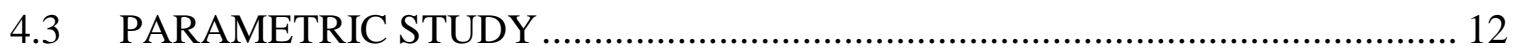

4.3.1 Influence of Spray Water Temperature .................................................... 12

4.3.2 Influence of Ambient Air Relative Humidity......................................... 13

4.3.3 Influence of Varying Entering Air Temperature at a Fixed Humidity Ratio

4.3.4 Influence of Face Velocity …......................................................... 15

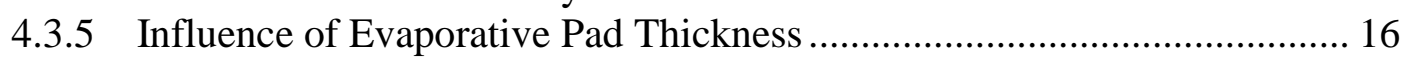

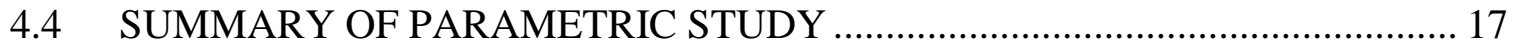

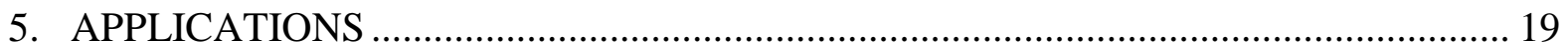

5.1 DOE BENCHMARK COMMERCIAL BUILDINGS AND LOCATIONS ......... 19

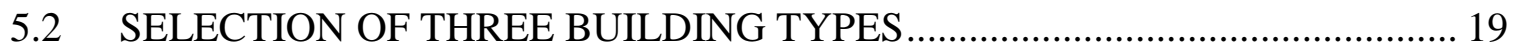

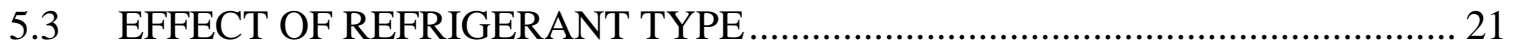

5.4 ANNUAL ENERGY SAVINGS AND PEAK POWER REDUCTION OF 3 BUILDING TYPES IN 16 CLIMATE ZONES.................................................... 22

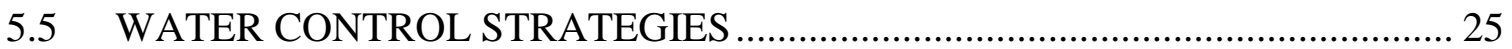

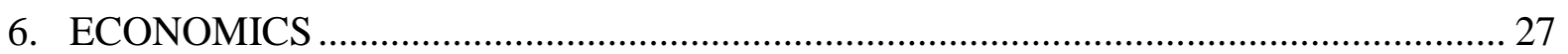

6.1 UTILITY RATE STRUCTURE ................................................................. 27

6.2 ANNUAL ELECTRICITY SAVINGS AND COST OF WATER ....................... 27

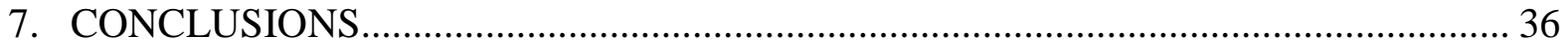

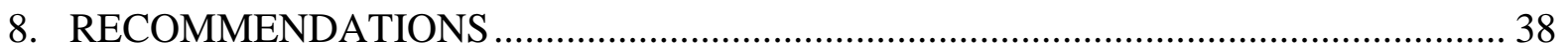

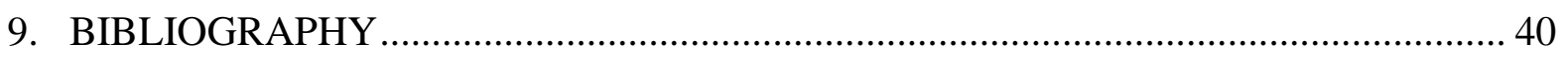

APPENDIX A. EQUIPMENT CURVES IN ENERGYPLUS ........................................ A-1

APPENDIX B. MULTIPLE VARIABLE ANALYSIS USING 2-LEVEL DESIGN-OF-

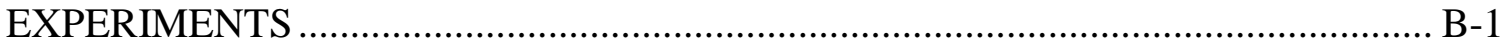

APPENDIX C. TABLES OF ANNUAL ENERGY SAVINGS AND PEAK LOAD

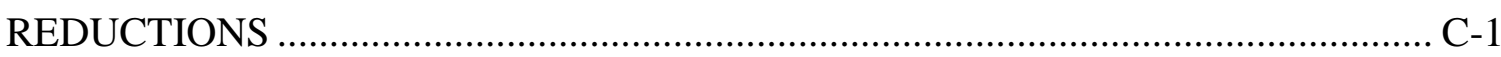

APPENDIX D. TABLES OF ECONOMICS ........................................................ D-1 



\section{LIST OF FIGURES}

1 Comparisons of the effectiveness-NTU model (this work), and EnergyPlus

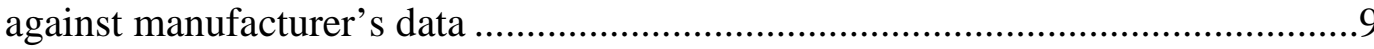

2 Relative deviations from manufacturer's data predicted by the effectivenessNTU model (this work) and EnergyPlus .............................................................10

3 Prediction of pad thickness from EnergyPlus and from the effectivenessNTU model (this work) and comparison with manufacturer's data ......................10

Pad water temperature as a function of entering water temperature

Variation of WB efficiency, water evaporation rate, and Second Law losses as a function of entering water temperatures

Dry bulb (DB) temperature drop and water evaporation rates are strongly dependent on entering air relative humidity $(\mathrm{RH})$

Wet bulb (WB) efficiency and Second Law losses with RH

DB temperature drop as a measure of pre-cooling at various entering air temperatures at the fixed humidity ratio

Pad WB efficiency and Second Law loss as a function of entering air temperature

Pad WB efficiency and Second Law loss as a function of air face velocity

11 Pad thickness significantly influences WB efficiency and Second Law losses

12 Medium office building in Phoenix, Arizona: Percentage of annual building load that is delivered in each temperature bin

13 Supermarket in Phoenix, Arizona: Percentage of annual building load that is delivered in each temperature bin

14 Annual savings depend on the building type and the WB efficiency ..................21

15 Annual energy savings for a medium office building with two-speed unit and WB efficiency fixed at 0.7 in all 16 climate zones

16 Peak power reduction for a medium office building with two-speed unit and WB efficiency fixed at 0.7 , in 16 climate zones .

17 Percentage of energy savings due to pre-cooling relative to no pre-cooling when water is sprayed at all ambient temperatures and wet bulb efficiency of 0.7 , and COP $=3$

18 Percentage of energy savings due to pre-cooling relative to no pre-cooling when water is sprayed after ambient temperature equals or exceeds $90^{\circ} \mathrm{F}$

19 Percentage of energy savings due to pre-cooling relative to no pre-cooling at all ambient temperatures

20 Percentage of energy savings due to pre-cooling relative to no pre-cooling when water is sprayed after ambient temperature is equal to or exceeds $90^{\circ} \mathrm{F} \ldots . .32$

21 Percentage of savings due to pre-cooling relative to no pre-cooling at all ambient temperatures

22 Percentage of energy savings due to pre-cooling relative to no pre-cooling at all ambient temperatures. 
23 Percentage of energy savings due to pre-cooling relative to no pre-cooling when water is sprayed after ambient temperature is equal to or exceeds $90^{\circ} \mathrm{F} . . . .35$

A.1 Total cooling capacity correction ratios of R-22 and R-410A varying with outdoor air dry bulb temperature and fixing indoor wet bulb at $67^{\circ} \mathrm{F}$.

A.2 EIR correction ratios of R-22 and R-410A varying with outdoor air temperature and fixing indoor $\mathrm{WB}$ at $67^{\circ} \mathrm{F}$.

A.3 Comparisons of EIR correction ratios between baseline R-410A equipment curve and equipment of different sizes, manufacturers, and refrigerants.

A.4 Comparisons of capacity correction ratios between baseline R-410A equipment curve and equipment from different sizes, manufacturers and refrigerants.

B.1 Influential variables for the pre-cooling effect. .............................................

B.2 Standardized effects of equipment factors on annual energy saving (see Table B.1 for the terms).

B.3 Standardized effects of equipment factors on peak power reduction (see Table B.1 for the terms).

B.4 Standardized effects of environment factors on annual energy saving (see

Table B.2 for the terms).

B.5 Standardized effects of environment factors on peak power reduction (see Table B.2 for the terms). 


\section{LIST OF TABLES}

Table

1 Three benchmark commercial buildings selected for this study .19 Medium office building: Annual energy savings and peak power reduction for 16 cities

Secondary school building: Annual energy savings and peak power reduction in 16 cities.... Supermarket: Annual energy savings and peak power reduction in 16 cities .......25

Water rates in seven cities

A.1 Rooftop equipment product information .................................................... A-5

B.1 Matrix of 2-level design-of-experiments for equipment factors..........................

B.2 Matrix of 2-level design of experiments for environment factors .......................

C.1 Energy assessments, medium office, R-410A, present........................................2

C.2 Energy assessments, medium office, R-22, present...........................................

C.3 Energy assessments, secondary school, R-410A, present..................................

C.4 Energy assessments, secondary school, R-22, present .....................................5

C.5 Energy assessments, supermarket, R-410A, present ........................................6

C.6 Energy assessments, supermarket, R-22, present ...........................................

C.7 Energy assessments, medium office, R-22, post-1980 …..................................

C.8 Energy assessments, secondary school, R-22, post-1980 ..................................9

C.9 Energy assessments, supermarket, R-22, post-1980 …......................................10

C.10 Energy assessments, secondary school, R-22, pre-1980 ...................................11

C.11 Energy assessments, supermarket, R-22, pre-1980 ….....................................12

D.1 Water and electricity rates for selected cities .......................................... D-1

D.2 Nominal total cooling capacities (baseline equipment tonnages sum) .............. D-1

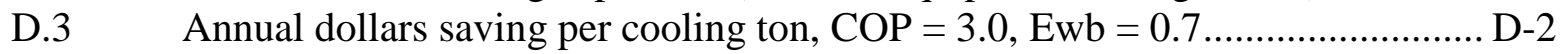

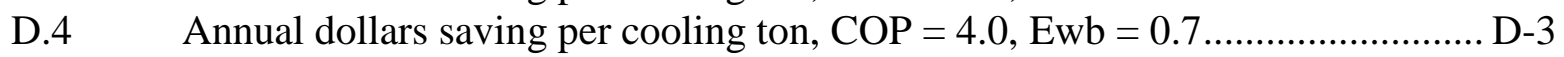

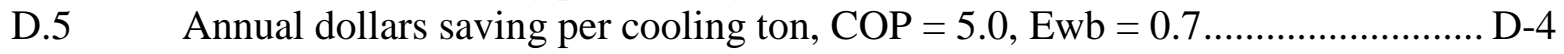

D.6 Annual dollars saving per cooling ton, $\mathrm{COP}=3.0, \mathrm{Ewb}=0.9 \ldots \ldots \ldots \ldots \ldots \ldots \ldots . . . . . . . . . . .5$

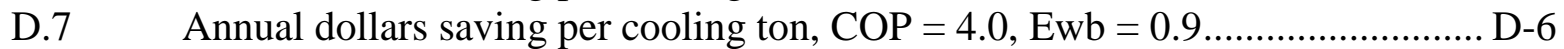

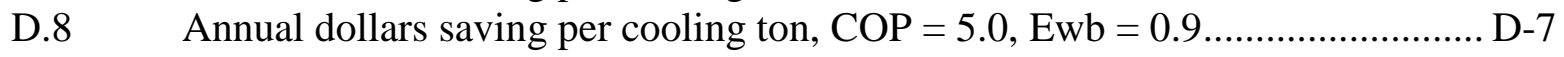





\section{ACKNOWLEDGMENTS}

This project was funded by the U.S. Department of Energy (DOE), Commercial Buildings Integration Program, BT0201000/1004212 under the direction of Drury Crawley, the DOE Headquarter Technology Development Manager. Van Baxter and Bill Craddick served as ORNL Project Managers. Moonis Ally, Bo Shen and Keith Rice were the principal investigators. The authors thank DOE sponsors for their encouragement and support. We also express our thanks to several equipment manufacturers. Munters Corporation provided us performance data and information on pad geometries. Lennox Corporation provided us product information. EVAPORCOOL provided us with energy savings and payback periods as reported by their large commercial customers.

Appreciation is also expressed to the ORNL technical editors, Amy Harkey and Priscilla Henson for their editorial skills. 



\section{EXECUTIVE SUMMARY}

Evaporative condenser pre-cooling expands the availability of energy saving, costeffective technology options (market engagement) and serves to broaden the range of options in upcoming codes and equipment standards (impacting regulation). Commercially available evaporative pre-coolers provide a low cost retrofit for existing packaged rooftop units, commercial unitary split systems, and air cooled chillers. We map the impact on energy savings and peak energy reduction in three building types (medium office, secondary school, and supermarket) in 16 locations with four levels of pad effectiveness and show the effect for HVAC systems using either refrigerants R22 or R410A (See Section 5.4).

EnergyPlus simulations are conducted with an improved algorithm for estimating the condenser pre-cooling wet bulb efficiency. EnergyPlus version 5.0.0 provides an option for a curve-fit form of calculating evaporative cooling efficiency (currently available only for evaporative pads used for space cooling, not condenser precooling). This option requires a large body of empirical data to obtain the 11 parameters required in the polynomial equation and, being a general curve fit, it is also not physically meaningful. Our study departs from this approach by presenting an alternative mathematical model that is physically intuitive, simpler in form, and provides better agreement with manufacturer's data.

In this report, we describe the simpler algorithm and provide the metrics that show how it is an improvement over the algorithm used in EnergyPlus version 5.0.0. We then generate performance values that can be directly input into EnergyPlus for simulations. By this process, we examine the annual and peak energy reductions of three building types (medium office, secondary school and supermarket) in 16 locations within the U.S. These three building types were chosen because they have distinctive loads, zones, and equipment. In addition to performing the requisite calculations, computer algorithms were developed for use with EnergyPlus to simulate the performance of commercial units under a variety of operating parameters. Performance maps were generated and estimated energy savings and peak demand reductions were calculated. Performance curves that were used in these EnergyPlus simulations were shared with the National Renewable Energy Laboratory (NREL) and with the Florida Solar Energy Center (FSEC) for possible inclusion in the next update to EnergyPlus.

From our present study we conclude that:

- Evaporative pre-cooling technology has the potential to be deployed immediately at scale for annual power savings and peak power demand reduction in many parts of the country.

- Evaporative cooling expands the availability of energy saving, cost-effective technology options (market engagement) and serves to broaden the range of options in upcoming codes and equipment standards (impacting regulation). Commercially available evaporative pre-coolers provide a low cost retrofit for existing packaged rooftop units, commercial unitary split systems, and air cooled chillers.

- The polynomial curve-fit used in EnergyPlus needs a large amount of data to generate the 11 parameters used in the curve-fit equation, whereas the effectiveness-NTU expression is much simpler, requires only two parameters and yields better accuracy than EnergyPlus.

- The media thickness and face velocity are the two major factors that impact the wet bulb efficiency. 
- For a direct evaporative cooling process, the wet bulb efficiency is insensitive to variation in water temperature, air entering temperature, and humidity. This implies that city water supply, stored rainwater, or recycled water may be used without sacrificing efficiency.

- Energy savings are much greater with refrigerant R410A than they are with R22.

- Evaporative pre-cooling provides the opportunity for annual energy savings and peak demand reduction.

Our analyses are based on three building types in 16 locations across the United States. In order to gain a comprehensive picture of the energy and peak demand reduction potential of this technology, this study should be expanded to 16 building types in all 16 locations mentioned in a recent report (P. Torcellini, 2008). Such a comprehensive study has not been undertaken, but our report has laid the necessary foundation for such an analysis. It is expected that this technology would have attractive payback periods (from one to two years, based on information provided by the manufacturer of EVAPORCOOL) for certain portions of the country. Annual savings are calculated on the basis of installing condenser precooling pad on an existing rooftop air conditioner. Actual savings may be more because condenser pre-cooling generally increases cooling capacity and hence the replacement unit may be downsized and cost less than the equipment it was replacing. The cost savings due to equipment downsizing was not part of this study. It would be possible to produce a software application which could be used by equipment owners, in which they would be able to enter their own utility rates and determine expected payback periods for their locations. 


\section{INTRODUCTION}

Evaporative cooling is a process that cools air through the simple evaporation of water. It is best suited for climates where the air is warm and dry (low humidity) because both conditions favor high rates of water evaporation that produces the cooling effect. Even in locations with moderate humidity, evaporative cooling may be used effectively, especially in the commercial and industrial sectors. In direct evaporative cooling, water is sprayed on a substrate that is placed in the air stream to be cooled. This technique may be used to cool indoor as well as outdoor air. Applied to outdoor air, the wetted media cools down the air entering the condenser coil and the process is called evaporative pre-cooling. Pre-coolers save energy because the entering air to the condenser coil is lower in temperature, reducing the lift imposed on the vapor compression cycle. These systems have the potential to be deployed immediately at scale for annual power savings and peak power demand reduction in many parts of the country at an attractive payback.

In a recent (2008) study (NREL/CP-550-43291) DOE developed a set of 16 benchmark commercial buildings across 16 locations representing $70 \%$ of the commercial building space. In this report we examine the benefits of evaporative pre-cooling in reducing annual energy consumption and peak load reductions in rooftop air conditioning (AC) units ranging from 10 to locations identified in the DOE study. These three building types were chosen because they have distinctive loads, zones, and equipment.

In addition to performing these calculations, the necessary computer algorithms were developed for use in EnergyPlus to simulate the performance of commercial units under a variety of operating parameters. Performance maps were generated and estimated energy savings and peak demand reductions were calculated. Performance curves that were used in these EnergyPlus simulations were shared with the National Renewable Energy Laboratory (NREL) and with the Florida Solar Energy Center (FSEC) for possible inclusion in the next update to EnergyPlus. Utility rates from a representative subset of the 16 locations identified in the DOE benchmark study allowed an estimate of simple payback periods and potential for wide scale adoption of this technology for energy and peak load reductions in the commercial building space.

In this report, we analyze three building types (medium office, secondary school, and supermarket) which are considered new construction for equipment sizing purposes. But what is the impact on energy use for older buildings characterized as pre-1980 and post-1980 (as given in the DOE commercial benchmark building database)? The impact of building generation is examined in detail in the Appendix. 



\section{PRE-COOLING METHODOLOGY IN ENERGYPLUS}

EnergyPlus is capable of simulating direct evaporative cooling for both indoor as well as outdoor components. The parameter for gauging efficiency of the evaporative pre-cooling process is the wet bulb (WB) efficiency, which is a measure of the drop in the dry bulb temperature due to the evaporative process. The wet bulb efficiency, $E_{w b}$, is defined in Eq. (1) as

$$
E_{w b=} \frac{T_{d b, i-} T_{d b, o}}{T_{d b, i}-T_{w b, i}}
$$

where $E_{w b}$ is the wet bulb efficiency; $T_{d b, i}$ and $T_{d b, o}$ are the entering and leaving air dry bulb temperatures, respectively; and $T_{w b, i}$ is the entering air wet bulb temperature. The maximum possible wet bulb efficiency can be unity when the leaving air dry bulb temperature is cooled to the entering wet bulb temperature. If the wet bulb efficiency is zero, the pad, substrate, or media is dry and evaporative cooling is absent.

In EnergyPlus, evaporative cooling is treated as an adiabatic heat transfer process, following a constant wet bulb temperature line in the psychrometric chart. The media geometry (thickness) and the face velocity (the velocity of air entering the outer surface of the media) are major independent variables that impact the wet bulb efficiency. Other factors like supply water temperature, flow rate, and external heat to the water stream have relatively minor impact. For direct evaporative cooling, EnergyPlus simulates the WB efficiency using a curve-fit polynomial equation with media thickness ("Depth") and face velocity ("Velocity") as the independent variables, as depicted in Eq. (2):

$$
\begin{aligned}
& E_{w b}=a_{1}+a_{2} \text { Depth }+a_{3} \text { Velocity }+a_{4} \text { Depth }^{2}+a_{5} \text { Velocity }^{2}+a_{6}(\text { Depth } \cdot \text { Velocity }) \\
& +a_{7}\left(\text { Depth }^{2} \cdot \text { Velocity }\right)+a_{8}\left(\text { Depth } \cdot \text { Velocity }^{3}\right)+a_{9}\left(\text { Depth }^{3} \cdot \text { Velocity }\right)+a_{10}\left(\text { Depth }^{2} \cdot \text { Velocity }^{3}\right) \\
& +a_{11}\left(\text { Depth }^{3} \cdot \text { Velocity }^{2}\right)
\end{aligned}
$$

The EnergyPlus curve-fit form of calculating evaporative cooling efficiency as given by Eq. (2) requires a large body of empirical data to obtain the 11 parameters required in the equation and, being a curve fit, is also not physically meaningful. Our study departs from this approach by presenting an alternative mathematical model that uses only two parameters. It is physically intuitive, is simpler in form, and provides better agreement with manufacturer's data. 



\section{ALTERNATE MODEL FOR IMPORTATION INTO EnergyPlus}

\subsection{MODEL DEVELOPMENT APPROACH}

The strategy of developing, testing, and comparing our alternate model against EnergyPlus predictions for large tonnage AC rooftop units is composed of the following segments: First, we synergize the work done by (J. E. Braun, S. A. Klein, J. W. Mitchell, 1989), (J. M. Wu, X. Huang, H. Zhang, 2009a) and (J. M. Wu, X. Huang, H. Zhang, 2009b) on the theoretical analysis and numerical investigation of heat and mass transfer in evaporative coolers to develop a simple and accurate model for commercial evaporative pre-cooling units. Second, we developed an algorithm whose output is imported into EnergyPlus to perform subsequent calculations. Third, we used design of experiments methodology to develop a two-level matrix of variables to ascertain the dominant variables and also to identify the variables that have a minimal influence on the pre-cooling process. We have a total of nine variables, each at two levels in the total matrix. Next, we perform simulations in EnergyPlus and then repeat those simulations using our algorithm to compare both sets of simulation results versus manufacturer's data to verify the significantly better predictive quality of our calculations as judged by agreement with manufacturer's performance data. We also performed an Exergy (Second Law) analysis of the evaporative cooling process to understand irreversibilities and how to improve the process. Last, we have produced performance tables and curves that can be used to provide the needed user-input to the current version of EnergyPlus. Development of a software module that resides within EnergyPlus is certainly a future option for those who have the authority to update EnergyPlus in newer versions to be released.

\subsubsection{Model Description}

Our model is based on the work of (J. E. Braun, S. A. Klein, J. W. Mitchell, 1989) who presented an innovative effective-NTU approach to model a wide range of cooling towers and cooling coils. Through detailed analytical work, Braun et al. (1989) treated the simultaneous heat and mass transfer process between sprayed water and entering air as an enthalpy-potential-driven process [see Eq. (3)], characterized by a Lewis Number of unity. Since the Lewis Number is defined as the ratio of thermal diffusivity to mass diffusivity, a value of unity means that the thermal and mass exchanges are of equal significance. Braun et al. (1989) proposed three new operational concepts in their model of simultaneous heat and mass transfer process: (1) that the heat and mass transfer rates are proportional to the difference of the enthalpy of saturated air at the entering water temperature and the enthalpy of entering air [see Eq. (3)]; (2) introduced a new parameter [see Eq. (4)], called the specific heat of saturated air, $C_{s}$, which can be obtained by averaging saturated air enthalpies at the entering and exit water temperatures; (3) defined the ratio of saturated air specific heat flow rate to the water specific heat flow rate, $m^{*}$ as in Eq. (5)

$$
\begin{gathered}
\dot{Q}=E_{H} \cdot \dot{m}_{\text {air }}\left(H_{S, \text { water }, i}-H_{\text {air }, i}\right) \\
C_{S} \equiv\left[\frac{d H_{s}}{d T}\right]_{T=T_{\text {water }}}
\end{gathered}
$$




$$
m^{*}=\frac{\dot{m}_{\text {air }} \cdot C_{s}}{\dot{m}_{\text {water }} \cdot C_{P_{\text {water }}}}
$$

where

$$
\begin{aligned}
\dot{Q}= & \text { total heat transfer rate, } \\
H_{s, \text { water }, i}= & \text { enthalpy of saturated air at the entering water temperature, } \\
H_{\text {air }, i}= & \text { enthalpy of entering air, } \\
E_{H}= & \text { heat and mass transfer effectiveness, defined later in Eq. (7) (Braun et al. } \\
& (1989) .
\end{aligned}
$$

With these three operational concepts, Braun, et al. defined the number of transfer units (NTU) and the effectiveness $E_{H}$ for evaporative cooling by a simple mathematical form. The NTU and $E_{H}$ both maintain the same form as that for sensible heat transfer applicable to a wide range of counter, parallel and cross-flow geometries. Assuming constant water temperature on | the surface of the wet media, we can get $E_{H}$ in the form of Eq. (7). Thus,

$$
\begin{gathered}
N T U=\frac{h_{a} \cdot A_{\text {surface }}}{\dot{m}_{\text {air }} \cdot C_{P_{\text {air }}}} \\
E_{H}=\frac{T_{d b, i}-T_{d b, o}}{T_{d b, i}-T_{s, \text { water }}}=1-\exp (-N T U)
\end{gathered}
$$

where

$$
\begin{aligned}
h_{a} & =\text { heat transfer coefficient between air and water stream, } \\
A_{\text {surface }} & =\text { heat transfer surface area, usually taken as the pad area, } \\
\dot{m}_{\text {air }} & =\text { mass flow rate of dry air, } \\
C_{P_{\text {air }}} & =\text { specific heat of dry air at dry bulb conditions, } \\
T_{\text {s,water }} & =\text { water surface temperature (constant) } .
\end{aligned}
$$

It should be noted that Braun et al. (1989) defines the wet bulb efficiency, $E_{H}$, given by Eq. (7) more generally than is described by $E_{w b}$ in Eq. (1). In the case of direct evaporative cooling, if the amount of water that is sprayed is much less than the amount of water resident on the pad, then $T_{s, w a t e r} \cong T_{w b, i}$ and $E_{H}$ becomes identical to $E_{w b}$. In practice, we want the amount of water sprayed on the pad to be small and, in fact, commercial equipment makers control water supply very diligently to apply a fine mist, just enough to wet the pad surface area.

Under these conditions, Wu et al. (2009a) combined Eq. (1) and Eq. (7), taking $T_{s, \text { water }}=$ $T_{w b, i}$ to yield

$$
E_{w b}=1-\exp (-N T U)
$$

Further, Wu et al. (2009b) formulated the following equations for the air heat transfer coefficient, $h_{a}$, the surface area for evaporative cooling, $A_{\text {surface }}$, and the air mass flow rate: 


$$
\begin{gathered}
h_{a}=a \times V_{\text {air }}^{m} \\
A_{\text {surface }}=c \times \delta \times A_{F} \\
\dot{m}_{\text {air }}=\rho_{\text {air }} \times V_{\text {air }} \times A_{F}
\end{gathered}
$$

where $a$, c, and $m$ in Eqs. (9) and (10) are constants specific to the pad, $\delta$ is the pad thickness, and $\rho$ is the density of ambient air. Substituting $\dot{m}_{\text {air }}$ from Eq. (11) in Eq. (6) gives the final form for the NTU:

$$
N T U=\frac{\alpha \cdot \delta}{\rho_{\text {air }} \times C_{P_{\text {air }}} \times V_{\text {air }}^{n}}
$$

where $\alpha$ and $n$ are empirical constants specific to the pad.

An overall mass balance on water gives the water mass flow rate in terms of the humidity ratios of the entering and leaving air, $\omega_{a i r, i}$ and $\omega_{\text {air }, o}$, respectively, given by

$$
\dot{m}_{\text {water }}=\dot{m}_{\text {air }}\left(\omega_{\text {air }, i}-\omega_{\text {air }, o}\right)
$$

Based on the approach of Braun et al. (1989) and Wu et al. (2009a, 2009b) our proposed coupled heat and mass transfer model utilizes Eqs. (3), (7), and Eqs. (8)-(13) to solve for $\dot{m}_{\text {water }}$ and $T_{s, \text { water }}$ iteratively. 



\section{MODEL VALIDATION}

In our model, the inputs are the entering air temperature and humidity, entering water temperature, pad (media) thickness, and the frontal air velocity. The wet bulb efficiency is the result of our calculations.

\subsection{COMPARISON OF ENERGYPLUS AGAINST ALTERNATIVE METHODOLOGY WITH MANUFACTURER'S DATA}

Our approach to model validation is based on a comprehensive set of data on TURBOdek®, a leading product line in commercial rooftop units. The data set consists of 13 levels of pad thicknesses ranging from 1 in. to 24 in., frontal air velocity from 250 fpm to $900 \mathrm{fpm}$ (12 levels) and wet bulb efficiencies ranging from $17.5 \%$ to $99.6 \%$. The $12 \times 13$ matrix of data points were used to fit the coefficients from $a_{1}$ through $a_{11}$ for the polynomial curve fit used by EnergyPlus as depicted by Eq.(2), and to obtain the parameters $\alpha$ and $n$ used in Eq. (12) by our model.

Our criteria for deciding goodness of a model is to demonstrate how closely the model predicts empirical data gathered by the manufacturer. A good model will show small deviations from actual field measurements. In our case, we have a matrix of $12 \times 13$ measurements to compare predictions of our model and that of EnergyPlus against extensive field data.

Figure 1 compares the predicted deviations of the EnergyPlus polynomial curve-fit calculations of the wet bulb efficiency and the effectiveness-NTU model versus manufacturer's data. The effectiveness-NTU method is significantly more accurate with prediction errors having a standard deviation of $0.67 \%$ with maximum deviation of $2.9 \%$. In contrast, EnergyPlus with the polynomial curve-fitted equation has a standard deviation of $4 \%$ with a maximum deviation of 31\%. Prediction deviations are defined as [(Model Prediction - Manufacturer’s data) $\times$ 100]/Manufacturer's data.

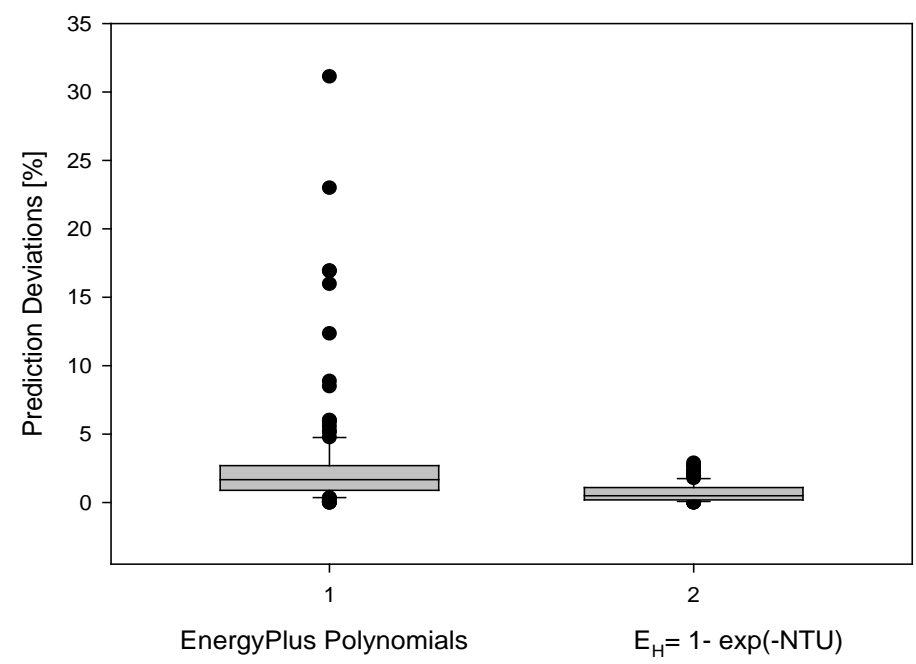

Fig. 1. Comparisons of the effectiveness-NTU model (this work), and EnergyPlus against manufacturer's data. 
Next we compare the predictions from the effectiveness-NTU model and the EnergyPlus approach against manufacturer's data over a wide range of face velocities. With EnergyPlus, big outliers are observed at the upper and lower bounds of the face velocity, whereas for the effectiveness-NTU approach (this work), the predictions are closer and uniformly distributed across a wide range of face velocities even at the upper and lower bounds of face velocity. These simulations are shown in Fig. 2.

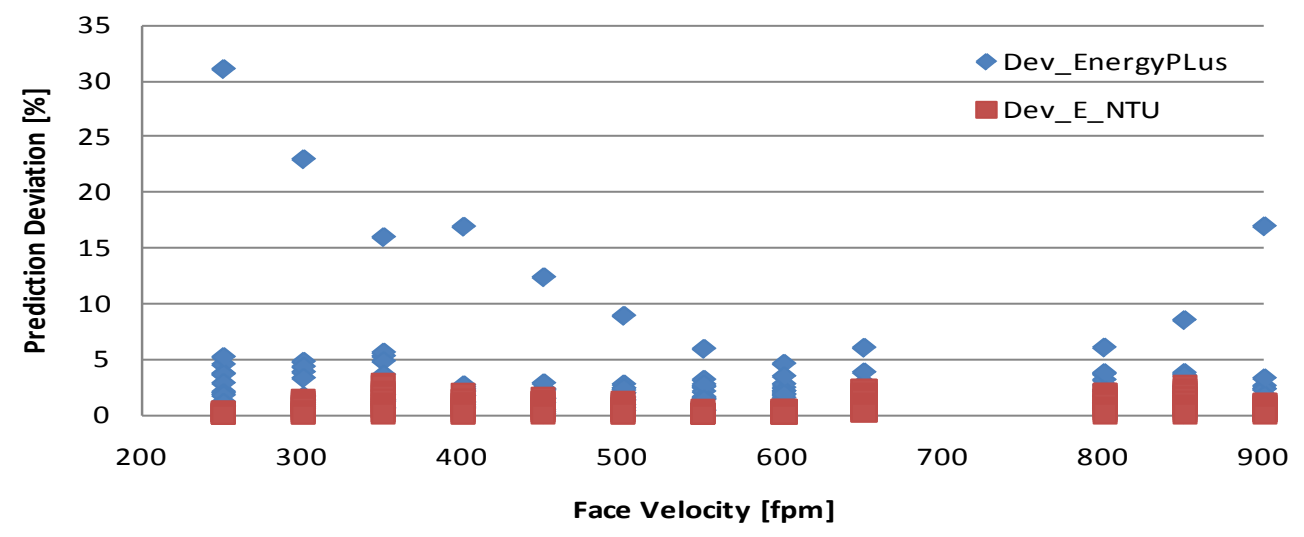

Fig. 2. Relative deviations from manufacturer's data predicted by the effectivenessNTU model (this work) and EnergyPlus.

In predicting necessary pad thickness, the effectiveness-NTU method provides much better predictions than EnergyPlus as shown in Fig. 3.

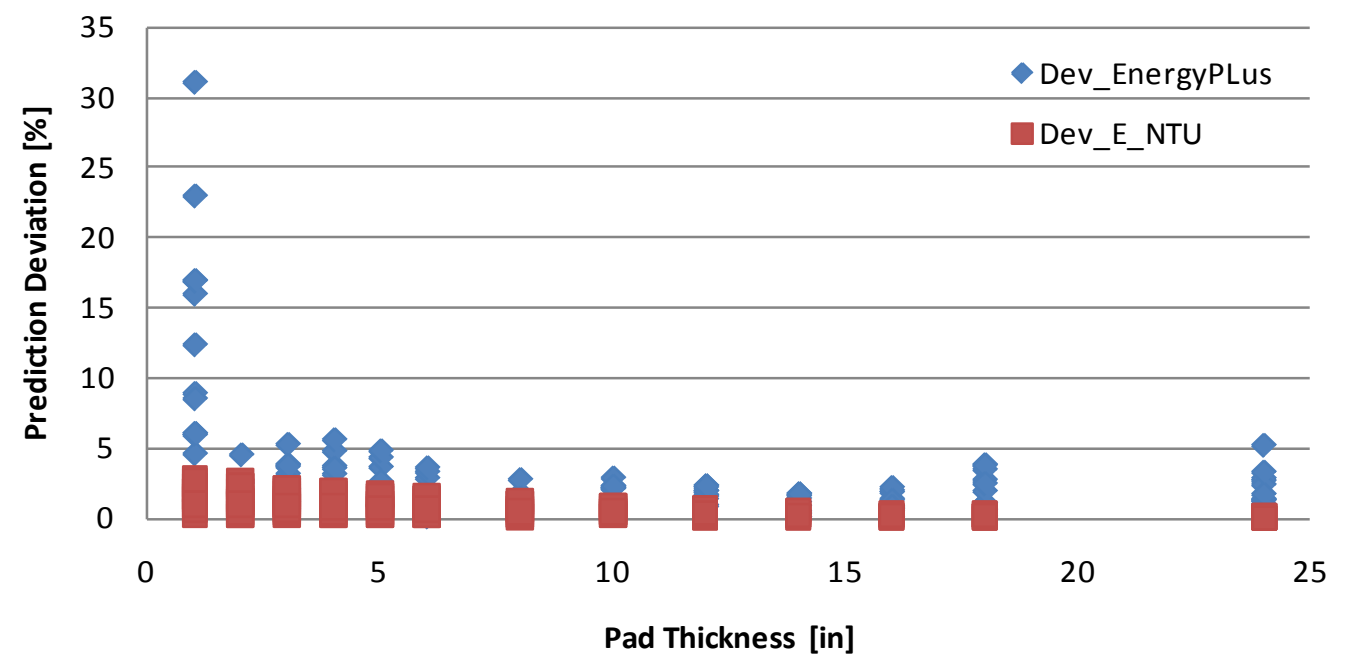

Fig. 3. Prediction of pad thickness from EnergyPlus and from the effectiveness-NTU model (this work) and comparison with manufacturer's data.

On the basis of these comparisons we conclude that the effectiveness-NTU model is simpler, and yet gives much better agreement with manufacturer's data than the approach used in EnergyPlus for evaporative cooling. The current EnergyPlus requires constant wet bulb efficiency for modeling condenser evaporative pre-cooling at each equipment speed. So our 
effectiveness-NTU model can be an efficient tool to predict the wet bulb efficiency as an input to EnergyPlus, based on the actual pad geometry and condenser frontal air velocity.

Hence, we have an improved algorithm whose output is readily imported into EnergyPlus to proceed with its simulation. Development of a software module that resides completely within EnergyPlus and has pad thickness and face velocity as user-adjustable inputs could be a useful option, if the EnergyPlus Development Team deems it desirable in a future upgraded version of the software. Upgrading EnergyPlus, and the time frame in which the upgrade should be accomplished is at the discretion of the EnergyPlus Development Team.

\subsection{SECOND LAW EFFICIENCY}

The value of availability destruction is the measure of the second law efficiency. Following the procedure outlined by (Warke, 1995), it should be noted that the availability calculations entail both thermo-mechanical as well as thermo-chemical terms and is given by

$$
\begin{aligned}
& \psi_{\text {air }}=\left(C p_{a}+\omega C p_{v}\right)\left(T-T_{0}-T_{0} \ln \frac{T}{T_{0}}\right)+(1+1.608 \omega) R T_{0} \ln \frac{P}{P_{0}}+ \\
& R T_{0}\left[(1+1.608 \omega) \ln \frac{1+1.608 \omega_{00}}{1+1.608 \omega}+1.608 \omega \ln \frac{1.608 \omega}{1.608 \omega_{00}}\right]
\end{aligned}
$$

where $C p_{a}$ and $C p_{v}$ are dry air and water vapor specific heats, respectively; $\omega$ and $\omega_{00}$ are the wet air specific humidity and environment air humidity, respectively; $R$ is the gas constant of dry air $(\mathrm{kJ} / \mathrm{kg} \bullet \mathrm{K}) ; P_{0}$ is the environmental dead state air pressure; and $P$ is the air pressure.

The availability of the water stream that is sprayed on to the pad is given by

$$
\psi_{\text {water }}=\left(H_{f, T}-H_{f, T_{0}}\right)+v_{f, T}\left(P-p_{s a t, T}\right)-T_{0}\left(S_{f, T}-S_{f, T_{0}}\right)-R T_{0} \ln \left(R H_{0}\right)
$$

where

$$
v_{f, T}=\text { water specific volume; }
$$

$P$ and $p_{\text {sat }, T}=$ water pressure and saturated pressure at the water temperature;

$H_{f, T}$ and $H_{f, 0}=$ specific water enthalpies at the water temperature and the environment temperatures, respectively;

$s_{f, T}$ and $s_{f, 0}=$ specific water entropies at the water temperature and the environment temperature, respectively;

$T_{0}=$ environment temperature $[\mathrm{K}]$;

$R=$ gas constant $[\mathrm{kJ} / \mathrm{kg} \cdot \mathrm{K}]$ of water;

$R H_{0}=$ environment (dead state) air relative humidity (dimensionless).

Since water is an incompressible liquid, the second term on the right hand side of Eq. (15), $v_{f, T}\left(P-p_{\text {sat }, T}\right)$ is small and may be ignored.

The expression for availability destruction per unit mass of entering dry air is given by 


$$
i_{c v}=\psi_{\text {air }, i}+\left(\omega_{o}-\omega_{i}\right) \psi_{\text {water }, i}-\psi_{\text {air }, o}
$$

For evaporative pre-cooling, since the entering air is from the environment (dead state), its availability $\psi_{\text {air, } i}$ is taken as zero. The availability destruction through the mixing process would be between the water stream and the cooled air leaving the condenser given by $\left(\omega_{o}-\omega_{i}\right) \psi_{\text {water }, i}$ and $\psi_{\text {air }, o}$, respectively.

Finally, the Second Law inefficiency is given by

$$
\text { Second Law Inefficiency }=\frac{i_{c v}}{\psi_{\text {air }, i}+\left(\omega_{o}-\omega_{i}\right) \psi_{\text {water }, i}}
$$

Therefore, inefficiency calculated by the Second Law is derived from Eq. (14). Conversely, the Second Law efficiency is just 100 minus the Second Law inefficiency.

\subsection{PARAMETRIC STUDY}

We utilize the effectiveness-NTU approach to investigate the influence of certain process variables on the wet bulb efficiency, the water evaporation rate, and the Second Law losses. For the parametric study both parameters in the NTU expression in Eq. (12) are fitted using the TURBOdek ${ }^{\circledR}$ data.

\subsubsection{Influence of Spray Water Temperature}

Water for pre-cooling may come from the city supply line, an underground source, a rain water storage tank or by some other means. Therefore, it is important to establish how water temperature may impact the pre-cooling process.

As an example, we fix the entering air temperature at $35^{\circ} \mathrm{C}$, $\mathrm{RH}$ at $20 \%$ (corresponding to a wet bulb temperature of $\left.18.9^{\circ} \mathrm{C}\right)$, air face velocity at $500 \mathrm{ft} / \mathrm{min}\left(2.54 \mathrm{~m} \cdot \mathrm{s}^{-1}\right)$, pad thickness at 6 in. $(0.152 \mathrm{~m})$ and vary the entering water temperature from 10 to $45^{\circ} \mathrm{C}$ to cover the range from below the entering air and WB temperatures. The results from these simulations shown in Fig. 4 suggest that the pad surface temperature is a very weak function of the entering water temperature because it varies slightly, from 18.8 to $19.11^{\circ} \mathrm{C}$ when the entering water temperature varies from 10 to $45^{\circ} \mathrm{C}$. Note that the pad water temperature remains the same as the air WB temperature when the entering water temperature is also at the same value $\left(18.8^{\circ} \mathrm{C}\right)$.

Figure 5 shows the relationship between entering water temperature on the pad wet bulb efficiency and Second Law losses. It can be seen that the wet bulb efficiency drops slightly from $71.4 \%$ to $69.9 \%$ with increasing entering water temperatures, while the Second Law loss is not sensitive to the entering water temperatures. It is interesting to observe that the water evaporation rate is fairly constant over this wide range of entering water temperatures. This indicates that the water consumption rate should essentially remain constant with different entering water temperatures. The customer may choose the most cost-effective water supply available - city supply, rainwater, or stored water. 


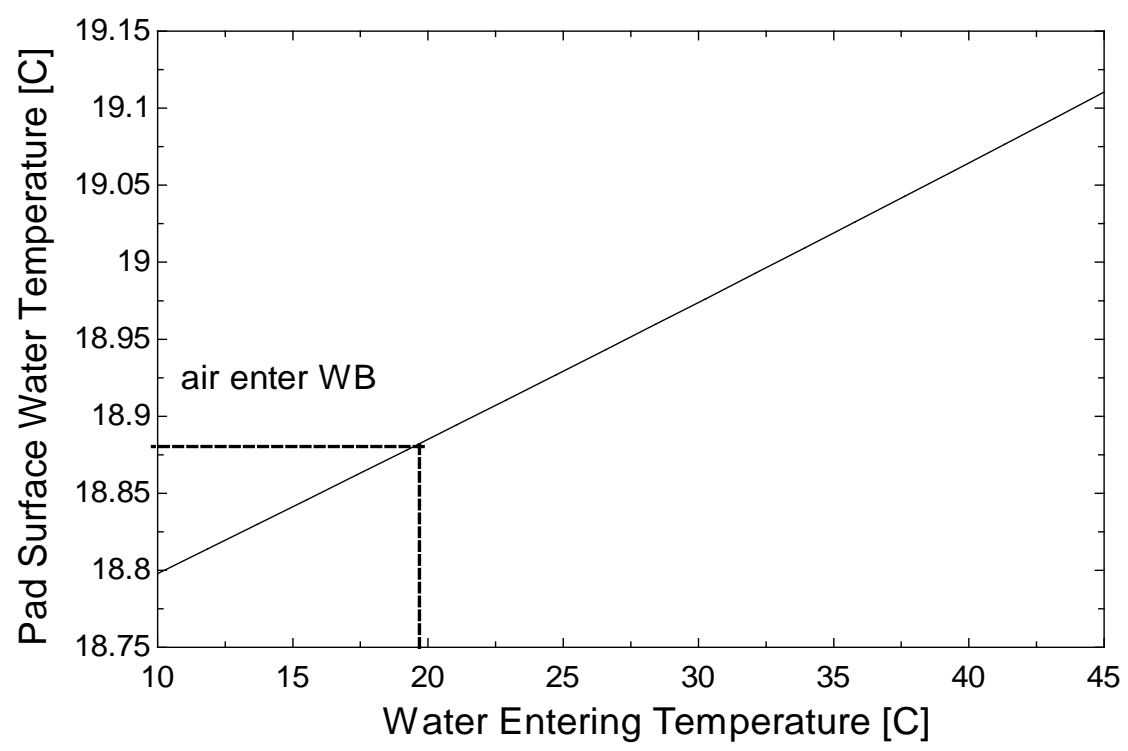

Fig. 4. Pad water temperature as a function of entering water temperature.

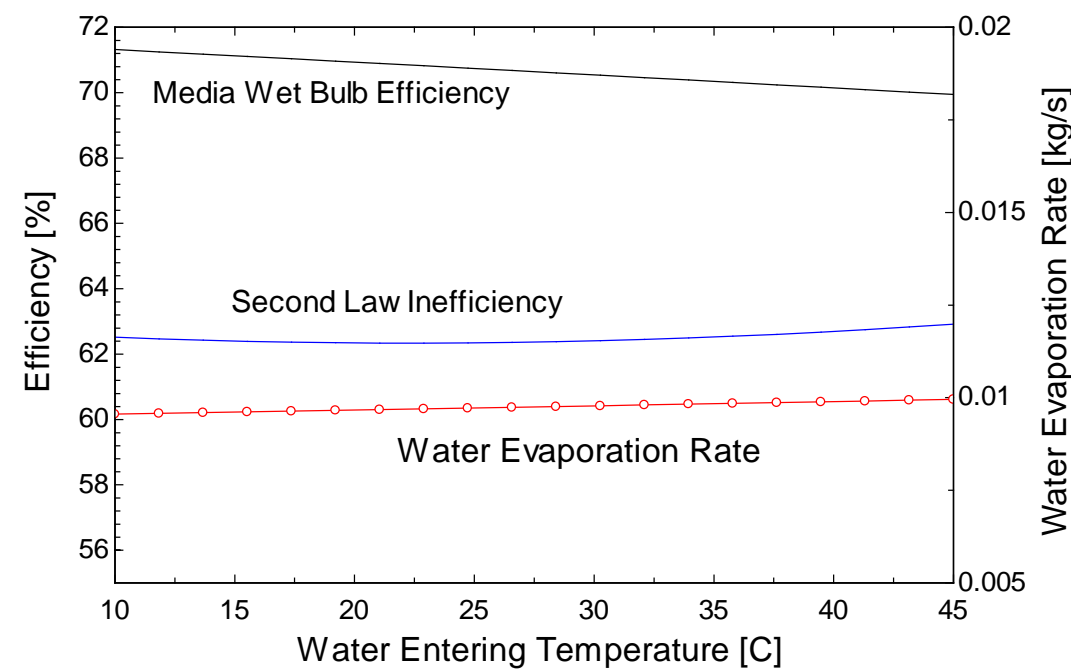

Fig. 5. Variation of WB efficiency, water evaporation rate, and Second Law losses as a function of entering water temperatures.

\subsubsection{Influence of Ambient Air Relative Humidity}

Low humidity or, equivalently, a large difference between the entering air WB and dry bulb (DB) temperatures favors evaporative pre-cooling. But how efficient is evaporative pre-cooling when the humidity is high, and what possible ranges of humidity can the process be carried out efficiently? Fig. 6 shows how much the DB temperature decrease may drop with increasing humidity. As RH increases, the effect of pre-cooling is diminished and the drop in DB temperature decreases. Simultaneously, due to the higher humidity, the evaporation rate also decreases. Fig. 7 shows the wet bulb efficiency and the Second Law losses with RH. While the wet bulb efficiency remains constant, the Second Law losses increase gradually with increasing 


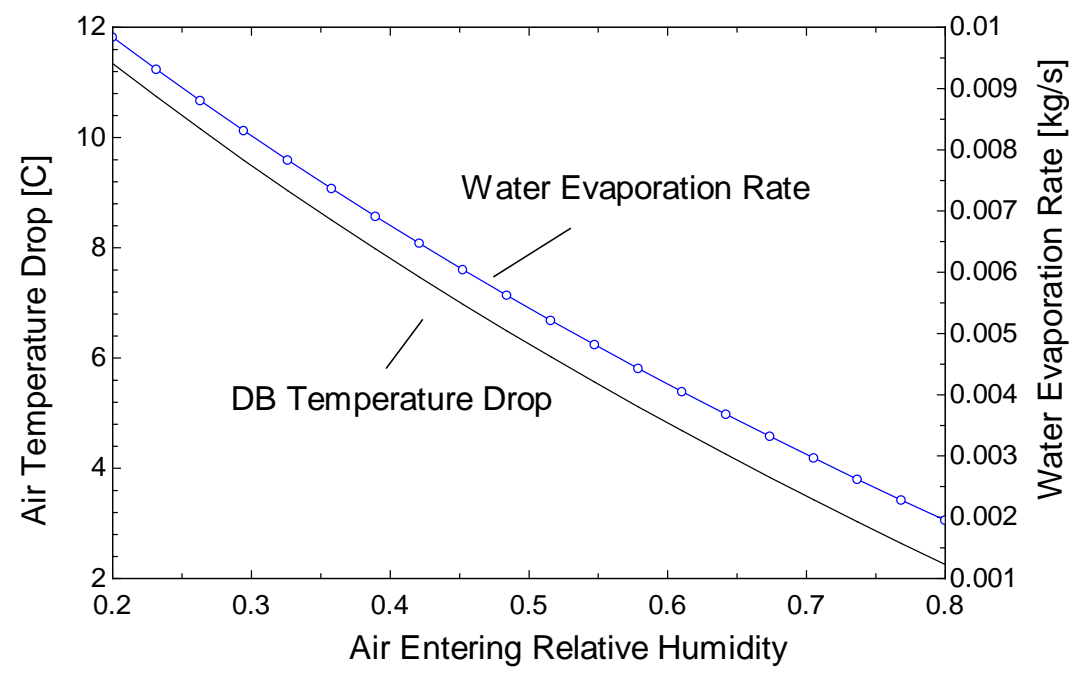

Fig. 6. Dry bulb (DB) temperature drop and water evaporation rates are strongly dependent on entering air relative humidity (RH).

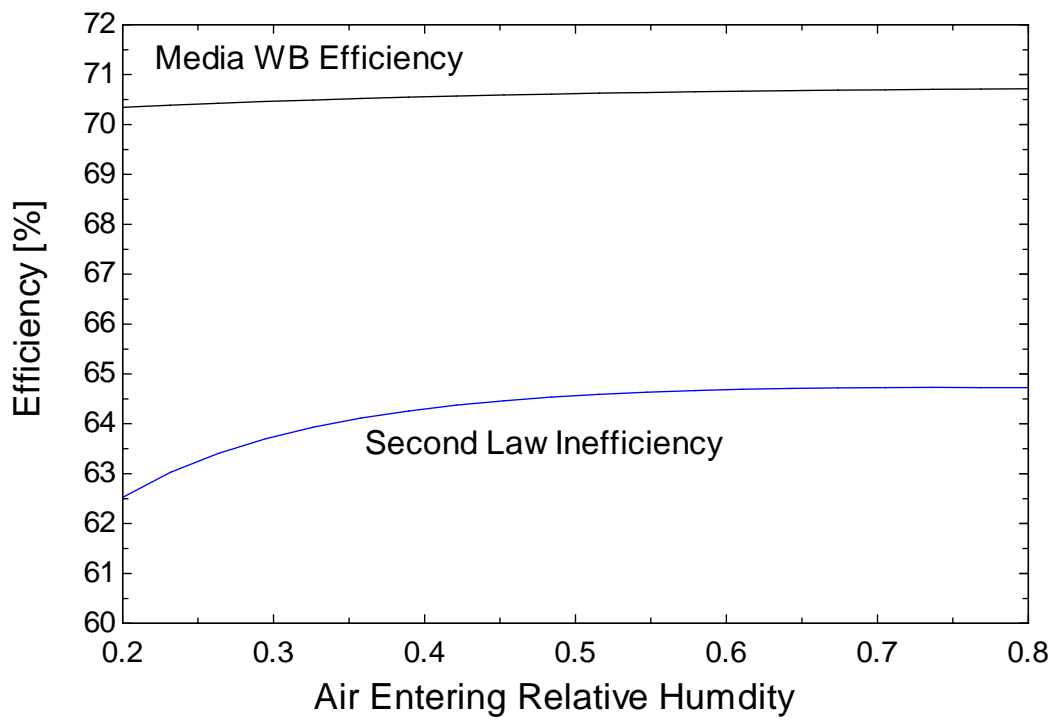

Fig. 7. Wet bulb (WB) efficiency and Second Law losses with RH.

$\mathrm{RH}$. Hence manufacturers may claim the same wet bulb efficiency, regardless of the climate zone, even though, as this suggests, the decrease in DB temperature drop may be quite dramatic as $\mathrm{RH}$ increases.

\subsubsection{Influence of Varying Entering Air Temperature at a Fixed Humidity Ratio}

Considering a typical day when the air DB temperature changes noticeably but the humidity ratio remains essentially constant, we examine the effect of changing $\mathrm{RH}$ on the pre-cooling effect by choosing a reference point for the entering air as $35^{\circ} \mathrm{C}$ and $40 \% \mathrm{RH}$ which corresponds to a humidity ratio, $\omega=0.01414\left(\mathrm{~kg} \mathrm{H}_{2} \mathrm{O} / \mathrm{kg}\right.$ dry air). If we fix $\omega$ at this value and vary the entering air temperature from $20^{\circ} \mathrm{C}$ to $45^{\circ} \mathrm{C}$ then the corresponding $\mathrm{RH}$ varies from $96 \%$ to 
$23.5 \%$, respectively. Therefore, when the entering air is at $20^{\circ} \mathrm{C}, \omega=0.01414$, it is quite saturated with a $\mathrm{RH}=96 \%$, and when the entering air is at $45^{\circ} \mathrm{C}, \omega=0.01414$, it is quite dry with a $\mathrm{RH}=23.5 \%$. Fig. 8 shows the temperature drop of the exiting air after pre-cooling when the entering air and water temperatures change between $25^{\circ} \mathrm{C}$ and $45^{\circ} \mathrm{C}$ at $\omega=0.01414$. At low entering air temperatures( for example, $20^{\circ} \mathrm{C}$ or $25^{\circ} \mathrm{C}$ ) the relative humidity is high and hence the cooling effect (expressed as the temperature drop) is small. At higher temperatures $40-45^{\circ} \mathrm{C}$, the entering air is relatively dry (low humidity) and therefore, the pre-cooling effect is much larger, of the order of $10-13^{\circ} \mathrm{C}$. As expected, the water evaporation rate at higher temperatures is also greater because the water evaporation rate increases as the entering air $\mathrm{RH}$ decreases at fixed entering water temperature. The pre-cooling effect would be most significant between 1 and 3 p.m. when the air temperature is high and $\mathrm{RH}$ is low. Also note that the pre-cooling effect (temperature drip) comes at the expense of water consumption.

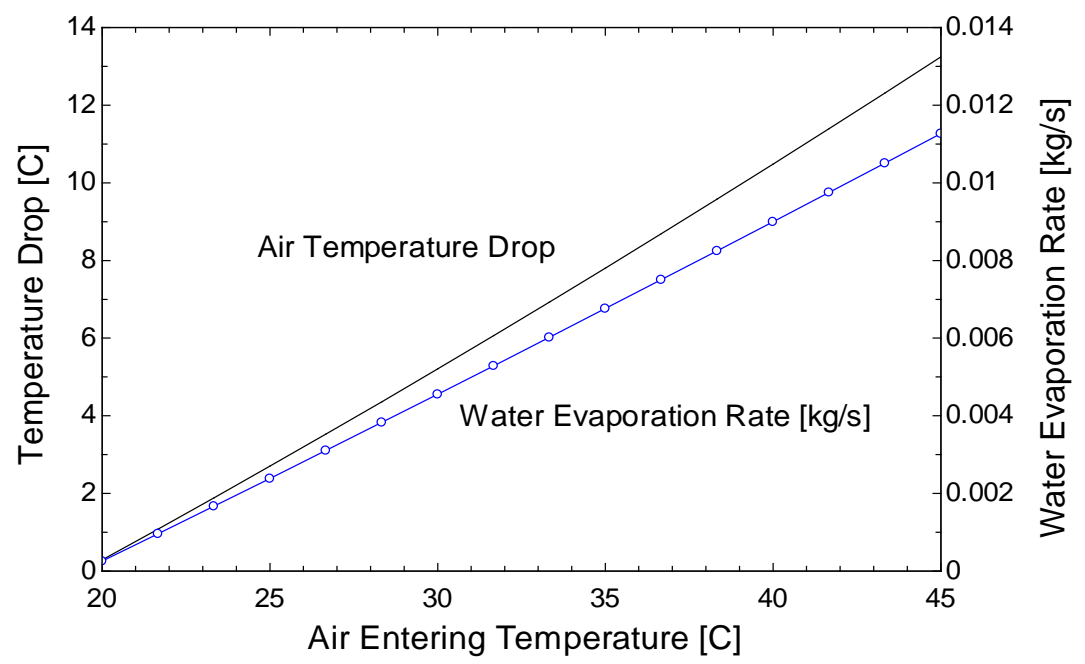

Fig. 8. DB temperature drop as a measure of pre-cooling at various entering air temperatures at the fixed humidity ratio. Reference condition for entering air is taken at $\omega=\mathbf{0 . 0 1 4 1 4}$, corresponding to $40 \% \mathrm{RH}$ at $35^{\circ} \mathrm{C}$.

The effect of increasing the entering air temperature from $20^{\circ} \mathrm{C}$ to $45^{\circ} \mathrm{C}$ at the same level of humidity ratio, $\omega=0.01414$ on the WB efficiency and the Second Law losses are shown in Fig. 9. Higher entering air temperature promotes the efficiency for both heat and mass transfer resulting in an increase of the WB efficiency and a decrease in Second Law losses.

\subsubsection{Influence of Face Velocity}

In contrast to the factors considered above, which have smaller effects on the wet bulb efficiency, face velocity and especially pad thickness influence the WB efficiency to a larger extent. Here, we arbitrarily fix the pad thickness at 6 in. $(0.152 \mathrm{~m})$, the entering air state point at $35^{\circ} \mathrm{C}$ and $\mathrm{RH}=20 \%$. With an entering air face velocity of $3 \mathrm{~m} / \mathrm{s}$ as the datum point, we run simulations of varying the face velocity from $30 \%$ up to $200 \%$ of the datum point value. The effect of face velocity on the WB efficiency and the Second Law loss is shown in Fig. 10. 


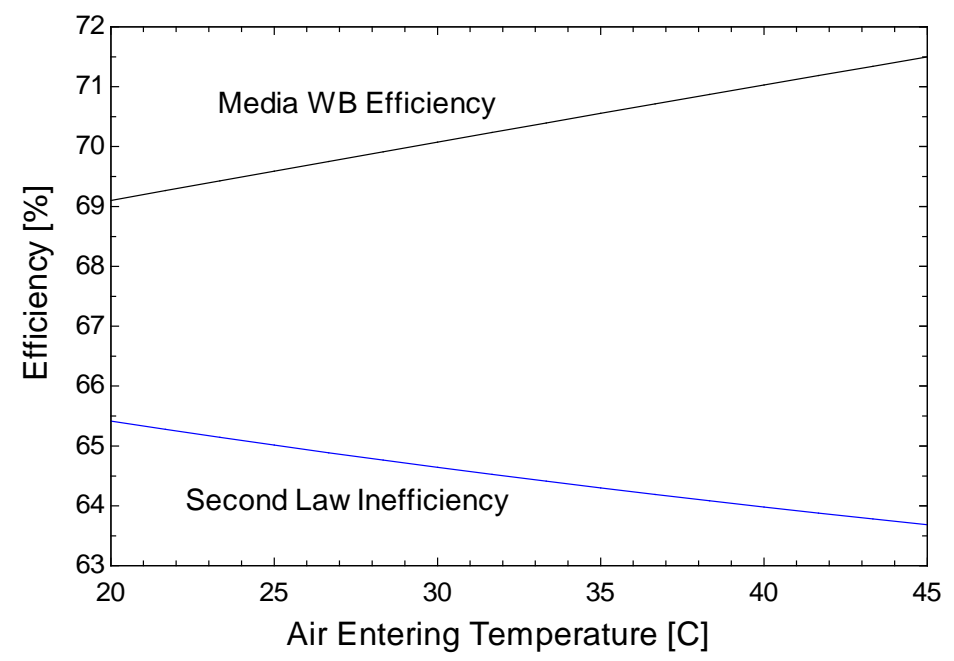

Fig. 9. Pad WB efficiency and Second Law loss as a function of entering air temperature. (Note that $\omega$ is fixed at 0.01414 corresponding to $35^{\circ} \mathrm{C}, 40 \% \mathrm{RH}$.)

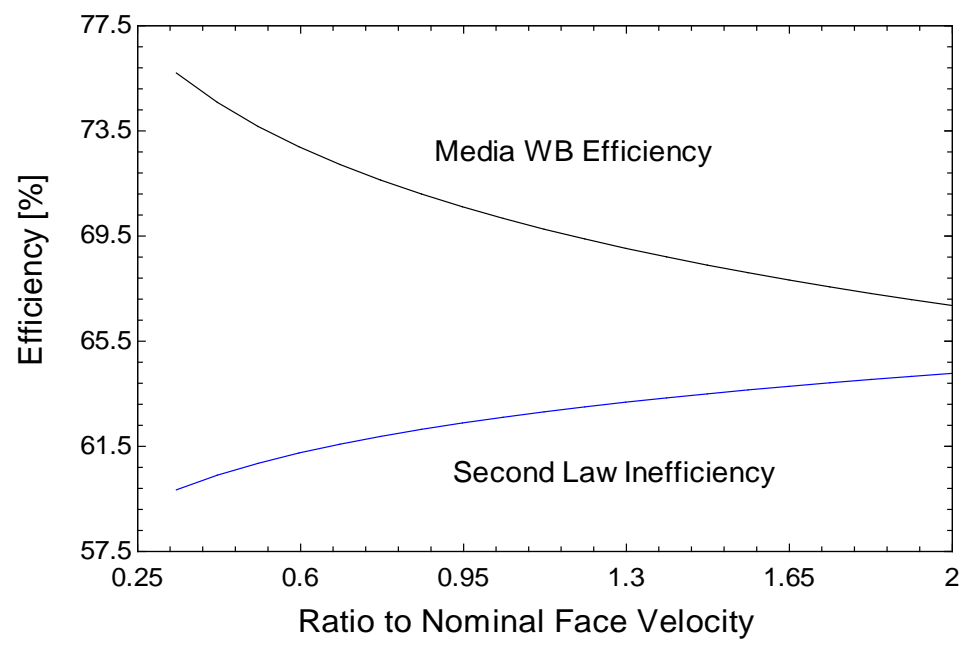

Fig. 10. Pad WB efficiency and Second Law loss as a function of air face velocity.

The reason why the WB efficiency increases with a low face velocity is because, for a fixed pad configuration, a smaller mass of air is cooled than would be the case if the face velocity was higher. Fig. 10 indicates that varying the face velocity from 30\% to 200\% from the datum level changes the WB efficiency by $10 \%$. The Second Law losses increase with increasing face velocity because the total entropy of mixing increases (higher mass of air at higher face velocity), indicating a less efficient heat and mass transfer process.

\subsubsection{Influence of Evaporative Pad Thickness}

Pad thickness has a big impact on WB efficiency. Starting with a pad thickness of 6 in. $(0.1524 \mathrm{~m})$, face velocity set at $500 \mathrm{ft} / \mathrm{min}\left(2.54 \mathrm{~m} \cdot \mathrm{s}^{-1}\right)$, entering water and air set at $35^{\circ} \mathrm{C}$, and air 
$\mathrm{RH}$ set at $20 \%$, the pad thickness is varied from $20 \%$ to $180 \%$ of the starting valve $(0.152 \mathrm{~m})$ and the WB efficiency and the Second Loss computed for that range of pad thickness.

Figure 11 shows that the WB efficiency increases with pad thickness. For very thin pads, the surface area is inadequate to allow sufficient evaporation-hence the pre-cooling effect is mitigated, resulting in a low WB efficiency. An increase in pad thickness allows more surface area for the water to evaporate, augmenting the WB efficiency. For small pad thicknesses, the Second Law inefficiency can be as large as $90 \%$, signaling an inefficient heat and mass transfer process.

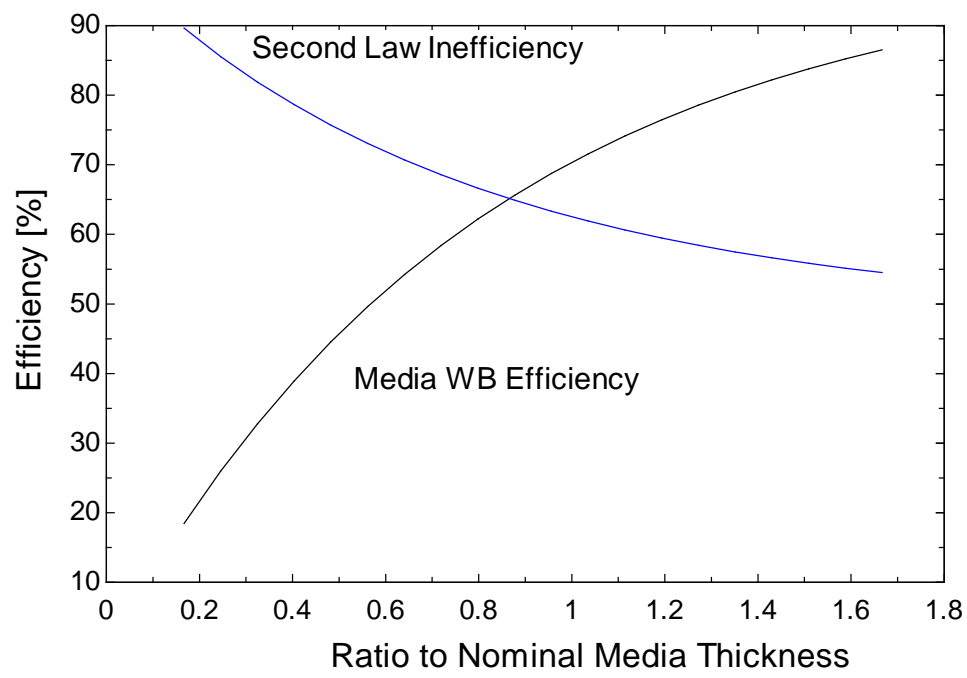

Fig. 11. Pad thickness significantly influences WB efficiency and Second Law losses.

\subsection{SUMMARY OF PARAMETRIC STUDY}

- The effectiveness-NTU method by Braun et al. (1989) and Wu et al. (2009a, 2009b) is a first principles, comprehensive approach and provides closer agreement with manufacturer's data than the curve-fit polynomial approach in EnergyPlus (Version 5.0.0). We have shown unequivocally that the effectiveness-NTU approach provides significantly closer agreement with manufacturer's data than the EnergyPlus curve-fit approach does.

- The polynomial curve-fit used in EnergyPlus needs a large amount of data to generate the 12 parameters used in the curve-fit equation, whereas the effectiveness-NTU expression is much simpler, requires only 2 parameters, and yields better accuracy than EnergyPlus.

- For a direct evaporative cooling process, the wet bulb efficiency is insensitive to variation in air entering temperature and humidity and essentially insensitive to entering water temperature.

- The media thickness and face velocity are the two major factors that impact the wet bulb efficiency. For equipment having a fixed media geometry and constant air flow rate, it is reasonable to specify (fix) a wet bulb efficiency. 



\section{APPLICATIONS}

Commercially available evaporative pre-coolers offer an opportunity for low cost retrofit for many existing packaged rooftop units, commercial unitary split systems, and air cooled chillers. Location and building-specific projections of energy savings and peak load reductions can encourage adoption and thus promote greater market penetration. It may also support consideration of building code changes that could mandate use of this technology for particular building types and climate zones. DOE's Commercial Building Integration Program's stated goal is to influence the energy performance of three billion square feet of commercial space per year by promoting the market penetration of a low-cost but effective technology to increase energy efficiency. Evaporative pre-cooling is an option that can impact a large section of the commercial market with a single technology, thus addressing DOE's goals of achieving "speed and scale.”

\subsection{DOE BENCHMARK COMMERCIAL BUILDINGS AND LOCATIONS}

DOE selected 16 building types classified as benchmark buildings that represent most of the commercial building stock, across 16 locations (representing all U.S. climate zones, NREL/CP-550-43291). In this study, we examine the effect of pre-cooling technology in three of the 16 building types in all 16 locations to gain an understanding of the extent to which annual and peak energy reductions are realistically possible. Descriptions of these buildings reside within the supplied EnergyPlus input files. The output from our effectiveness-NTU model was input to EnergyPlus, which performed the simulations for the various buildings in the particular climate zones, as the current EnergyPlus requires a constant wet bulb efficiency for modeling condenser evaporative pre-cooling at each equipment speed

\subsection{SELECTION OF THREE BUILDING TYPES}

We selected a medium office, a secondary school, and a supermarket for the three building types because they have very different equipment sizes, load profiles, zones, and uses. The building characteristics are shown in Table 1.

Table 1. Three benchmark commercial buildings selected for this study

\begin{tabular}{|l|c|c|c|c|c|}
\hline \multicolumn{1}{|c|}{ Building } & $\begin{array}{c}\text { Floor area } \\
\mathbf{( f t}^{2} \mathbf{)}\end{array}$ & $\begin{array}{c}\text { Number of } \\
\text { floors }\end{array}$ & Zones & DX coils & $\begin{array}{c}\text { Sizing } \\
\text { factor }\end{array}$ \\
\hline Medium office & 54,000 & 3 & 15 & 3 units, 2-speed & 1.33 \\
\hline Secondary school & 210,000 & 2 & 46 & 5 units, 1-speed & 1.5 \\
\hline Supermarket & 45,000 & 1 & 6 & 6 units, 1-speed & 1.2 \\
\hline
\end{tabular}

In addition to the three building types, our simulations covered three building generations (new, pre-1980, and post-1980) and two refrigerants (R-22 and R-410A) in 16 climate zones. For retrofit applications, the pad is directly added to the original rooftop unit sizes selected by Energy Plus as equipment upgrades. It shall be noted that this report only investigates the retrofit applications; possible equipment size reductions (and any equipment first cost savings) due to the precooling effect are not taken into account. 
Building types represent different load distributions. For example, in Phoenix, Arizona, the load profile in a medium office building is different from that in a supermarket as shown in Fig. 12 and Fig. 13, respectively. In cold weather, when the ambient temperature is low, the load in the supermarket is practically zero (no cooling needed, only perhaps heating), whereas in the medium office building heating and cooling may be needed depending on the zones in the building because the loads in the exterior portions are different from that in the interior portions. Most of the cooling load in the supermarket is in the hotter months, whereas in the medium office building, the cooling loads are distributed over more temperature bins.

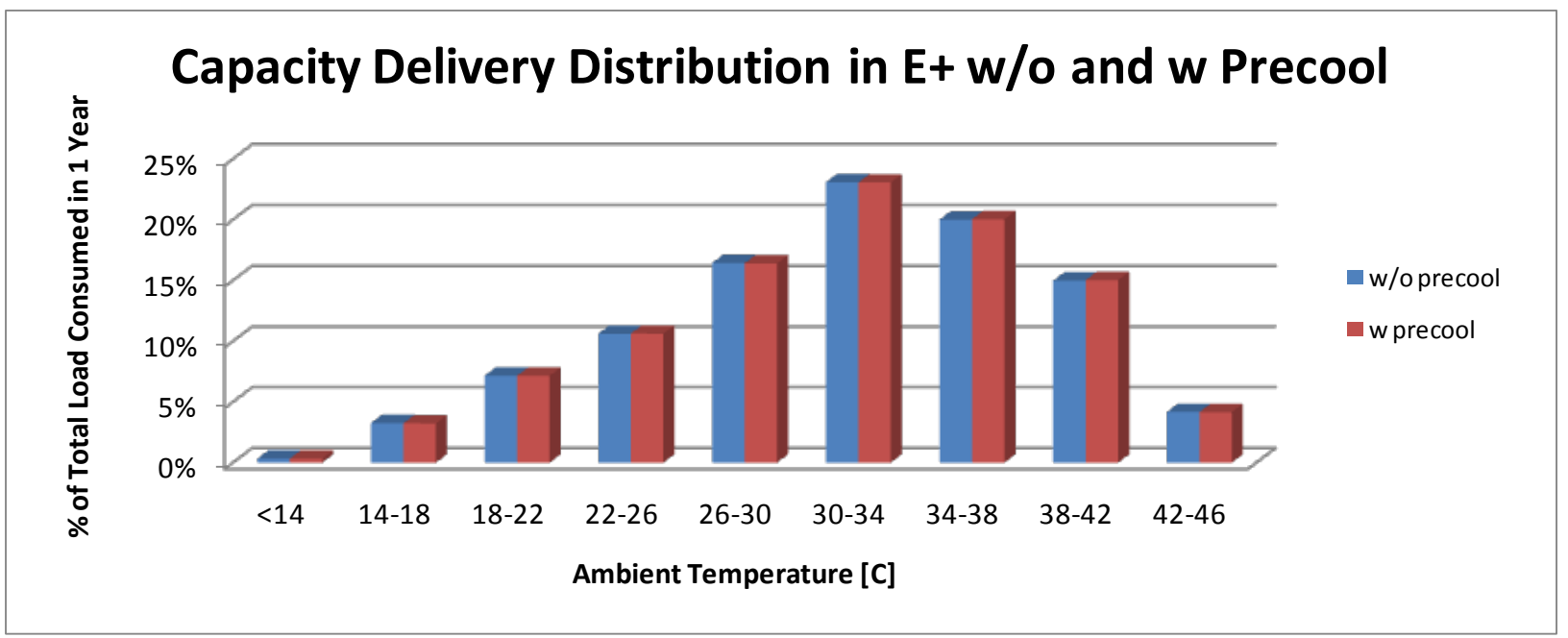

Fig. 12. Medium office building in Phoenix, Arizona: Percentage of annual building load that is delivered in each temperature bin.

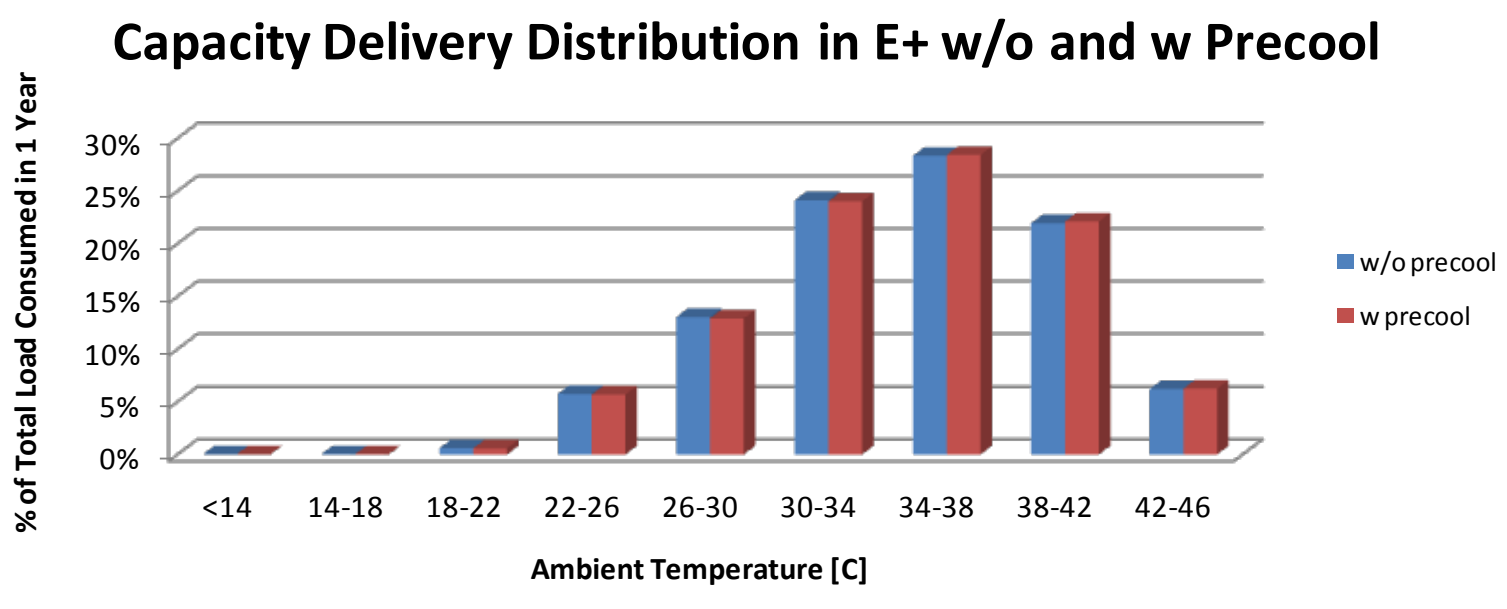

Fig. 13. Supermarket in Phoenix, Arizona: Percentage of annual building load that is delivered in each temperature bin. 
Using EnergyPlus, we estimate the annual power savings for R-410A rooftop equipment in Phoenix, AZ for the three classes of buildings: medium office, secondary school and supermarket, as shown in Fig. 14. Due to the different load profiles, the annual savings vary according to building type. Fig. 14 further exemplifies the benefit of using pre-cooling technology. Relative to no pre-cooling, the percentage of annual energy savings can be as high as $23 \%$ with a WB efficiency of 0.7 or as much as $27 \%$ with a higher WB efficiency of 0.9 (where many pre-cooling units operate). The decision to operate at a specific WB efficiency depends largely on the pad thickness and face velocity as discussed above and these are operating variables available to the HVAC engineer.

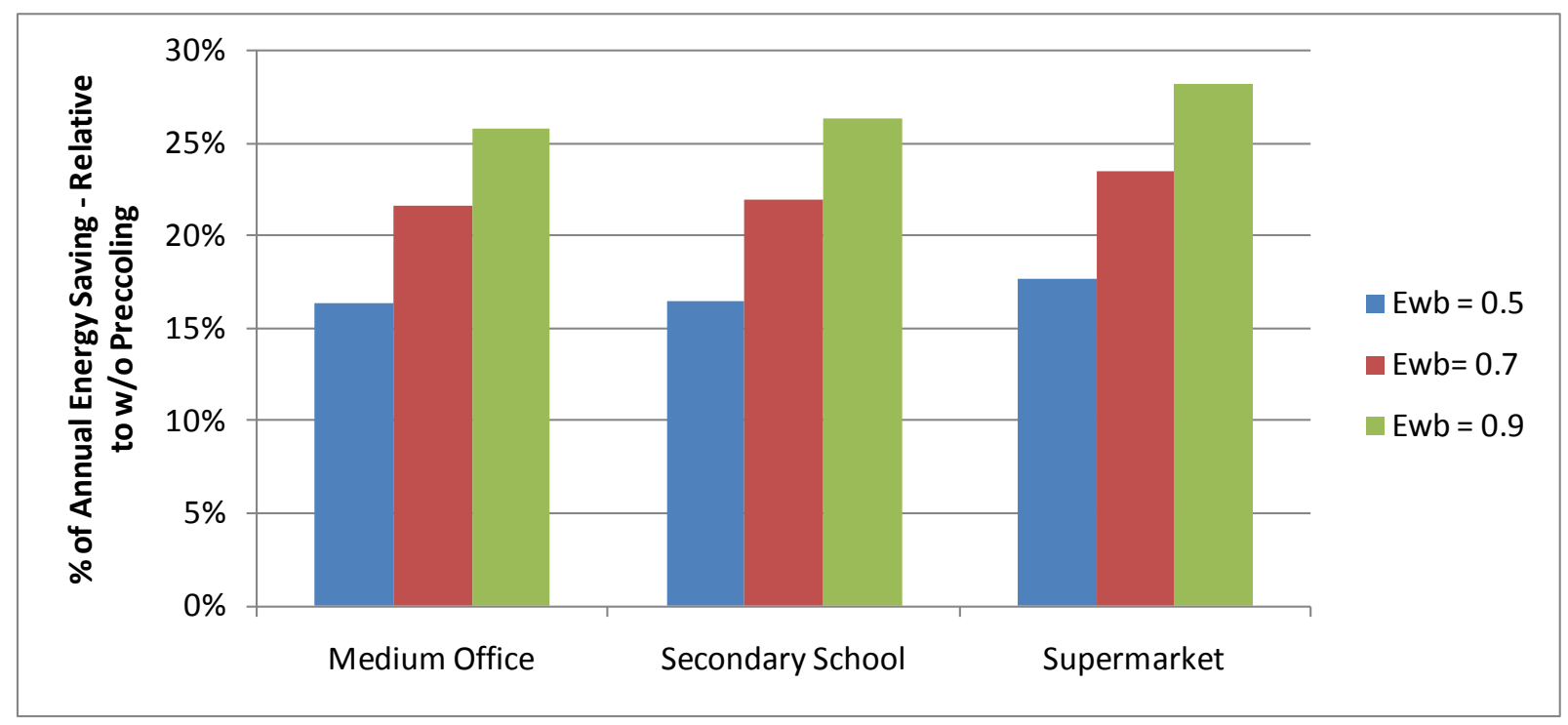

Fig. 14. Annual savings depend on the building type and the WB efficiency.

\subsection{EFFECT OF REFRIGERANT TYPE}

Older rooftop units use R-22 while newer models utilize R410A. We examined the effect of refrigerant type on annual energy and peak power reductions for a medium office building with a two-speed rooftop unit and WB efficiency of 0.7 in 16 climate zones as shown in Fig. 15 and Fig. 16. Clearly, the largest benefits are derived with the R-410A refrigerant in hot and dry climates. However, note that even in hot and humid climates such as Houston, Texas, the benefits with R410A are significantly higher than it is for R-22.

The effect of refrigerant type can be understood by noting that R410A condensing pressure operates near the critical region (where the refrigerant liquid and vapor become identical) and any lowering of the condenser temperature (as would be the case of evaporative cooling) causes the two-phase isotherm to move downwards from the apex of the critical region enabling the system to increase its cooling capacity and efficiency. In other words, the refrigerant operates over a larger enthalpy change across the two-phase region, resulting in improved overall condenser heat transfer effectiveness, and hence can reject more heat to the ambient for the same mass flow rate. Consequently, precooling has a more beneficial effect on energy savings for R410A systems, as compared with R22 units. 


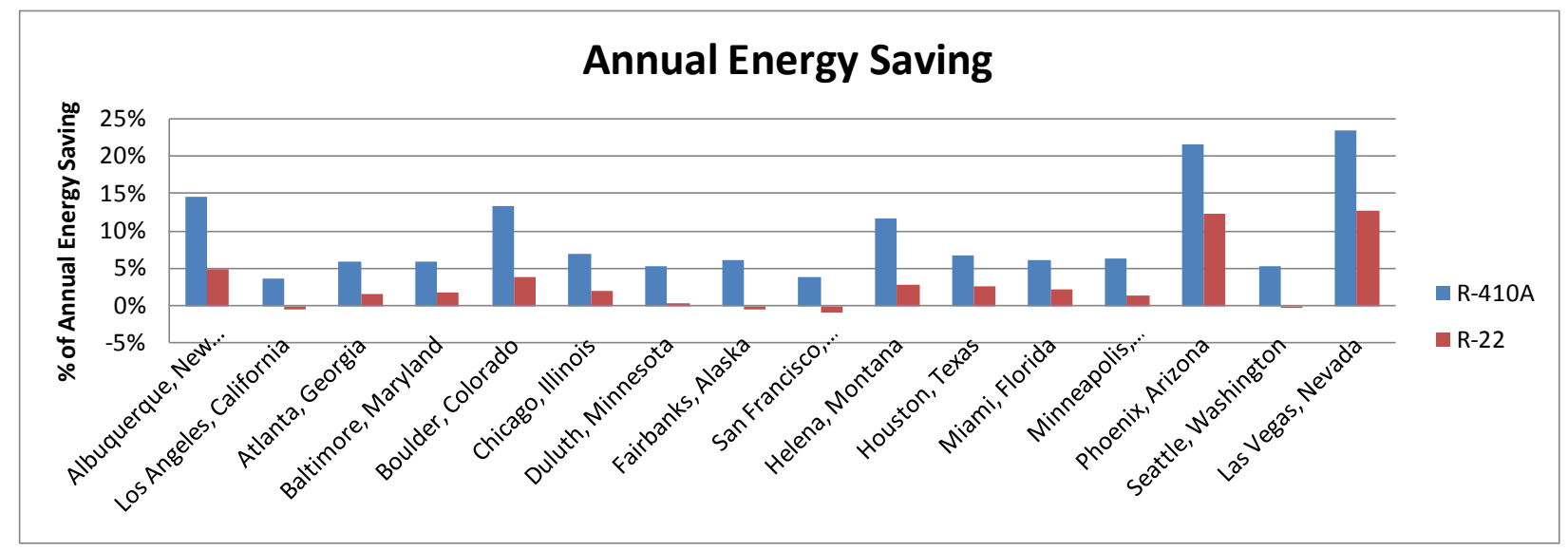

Fig. 15. Annual energy savings for a medium office building with two-speed unit and WB efficiency fixed at 0.7 in all 16 climate zones.

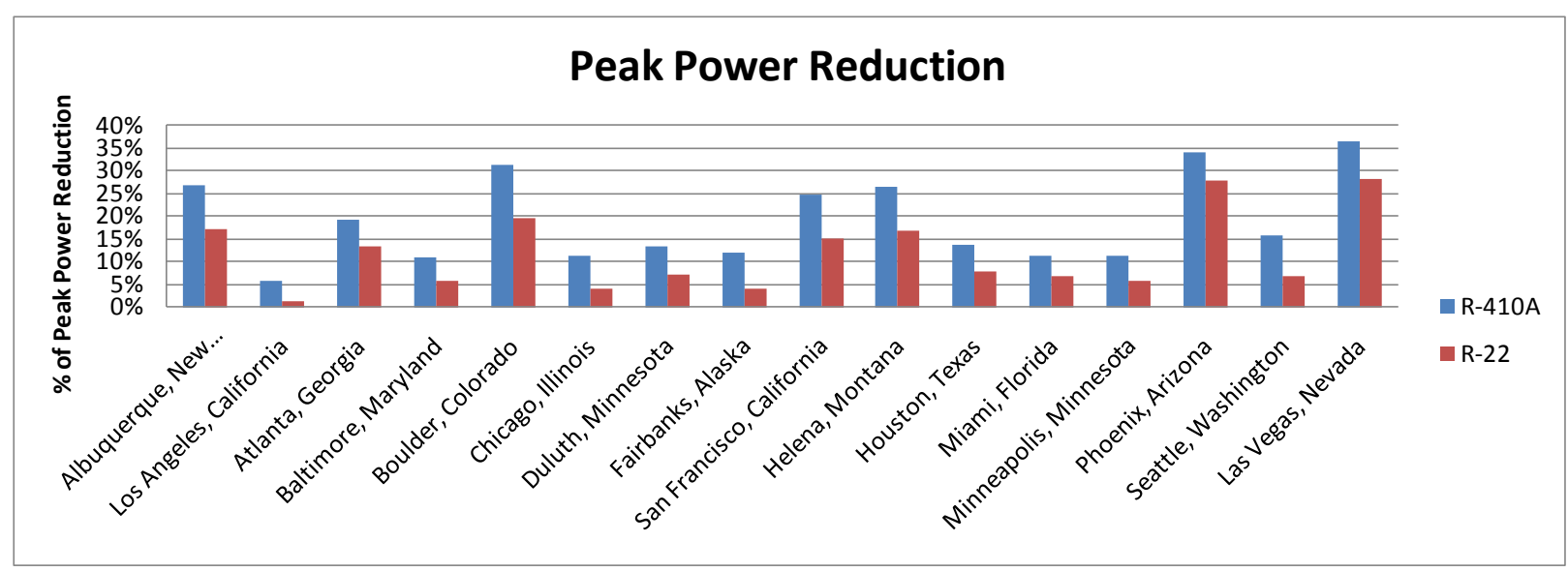

Fig. 16. Peak power reduction for a medium office building with two-speed unit and WB efficiency fixed at 0.7 , in 16 climate zones.

\subsection{ANNUAL ENERGY SAVINGS AND PEAK POWER REDUCTION OF 3 BUILDING TYPES IN 16 CLIMATE ZONES}

Evaporative cooling expands the availability of cost-effective technology options (market engagement) and serves to broaden the range of options in upcoming codes and equipment standards (impacting regulation). Commercially available evaporative pre-coolers provide a lowcost retrofit for existing packaged rooftop units, commercial unitary split systems, and air cooled chillers. We map the impact of energy savings and peak energy reduction in the 3 building types (medium office, secondary school, and supermarket) in 16 locations with a fixed pad thickness (giving an effectiveness of 0.816) and show the effect of both refrigerants, R22 and R410A.

Simulations are performed with EnergyPlus. In each of the three building types, there is tangible opportunity to reduce annual energy and peak power consumption if pre-cooling is used and if a switch is made from R-22 equipment to R-410A equipment. The selected pad wet bulb effectiveness of 0.816 was calculated using the newly proposed Effectiveness-NTU model. We chose the Munter's TURBOdek® pad with depth of 7.28 in. (in the manufacturer's standard 8”-thick assembly for commercial applications). The air frontal velocity was selected as 
$250 \mathrm{fpm}$, which was the actual data according to the 10-ton unit in the Lennox STRATEGOS product series used in the analysis. Inputting the calculated wet bulb efficiency into EnergyPlus, we obtain annual energy savings and peak power reductions as shown in Tables 2-4 below.

In addition to the above simulations of annual energy savings and peak power reductions based on available commercial products on the market, we completed numerous parametric studies for the three commercial buildings with three building generations (new, pre-1980 and post-1980) in all 16 locations. Our extensive simulations covered 3 wet-bulb efficiencies (0.5, 0.7, and 0.9); two refrigerant types (R-410A and R-22); cyclic effects; two-speed and singlespeed equipment; and part load performance at reduced indoor air flow. The conclusions were that building type, climate, refrigerant, and evaporative precooling pad design have a dominant effect on annual energy savings, peak load reduction and water use, whereas factors like singleor two-speed compressors, cyclic effects, etc have a nominal impact, with respect to relative annual energy savings and peak power reductions. For additional details please see Appendices.

Table 2. Medium office building: Annual energy savings and peak power reduction for 16 cities

\begin{tabular}{|c|c|c|c|c|}
\hline & \multicolumn{2}{|c|}{ Annual energy saving } & \multicolumn{2}{|c|}{ Peak power reduction } \\
\hline & $\begin{array}{c}\text { R410A } \\
\text { equipment }\end{array}$ & $\begin{array}{c}\text { R22 } \\
\text { equipment }\end{array}$ & $\begin{array}{c}\text { R410A } \\
\text { equipment }\end{array}$ & $\begin{array}{c}\text { R22 } \\
\text { equipment }\end{array}$ \\
\hline Albuquerque, New Mexico & $16.1 \%$ & $5.1 \%$ & $29.5 \%$ & $18.4 \%$ \\
\hline Los Angeles, California & $4.2 \%$ & $-0.5 \%$ & $6.7 \%$ & $1.8 \%$ \\
\hline Atlanta, Georgia & $6.9 \%$ & $1.9 \%$ & $22.1 \%$ & $14.9 \%$ \\
\hline Baltimore, Maryland & $7.0 \%$ & $2.0 \%$ & $12.7 \%$ & $6.7 \%$ \\
\hline Boulder, Colorado & $14.8 \%$ & $3.9 \%$ & $34.4 \%$ & $20.4 \%$ \\
\hline Chicago, Illinois & $8.1 \%$ & $2.2 \%$ & $12.6 \%$ & $4.7 \%$ \\
\hline Duluth, Minnesota & $6.1 \%$ & $0.5 \%$ & $15.2 \%$ & $7.9 \%$ \\
\hline Fairbanks, Alaska & $6.8 \%$ & $-0.5 \%$ & $13.5 \%$ & $4.2 \%$ \\
\hline San Francisco, California & $4.6 \%$ & $-0.9 \%$ & $27.8 \%$ & $16.3 \%$ \\
\hline Helena, Montana & $13.0 \%$ & $2.8 \%$ & $29.4 \%$ & $17.7 \%$ \\
\hline Houston, Texas & $7.8 \%$ & $3.0 \%$ & $15.4 \%$ & $8.9 \%$ \\
\hline Miami, Florida & $7.1 \%$ & $2.5 \%$ & $13.3 \%$ & $8.0 \%$ \\
\hline Minneapolis, Minnesota & $7.3 \%$ & $1.6 \%$ & $13.0 \%$ & $6.8 \%$ \\
\hline Phoenix, Arizona & $24.2 \%$ & $13.3 \%$ & $38.0 \%$ & $30.5 \%$ \\
\hline Seattle, Washington & $6.1 \%$ & $-0.2 \%$ & $17.6 \%$ & $7.5 \%$ \\
\hline Las Vegas, Nevada & $26.0 \%$ & $13.5 \%$ & $39.0 \%$ & $29.7 \%$ \\
\hline Average & $10.4 \%$ & $3.1 \%$ & $21.3 \%$ & $12.8 \%$ \\
\hline Max & $26.0 \%$ & $13.5 \%$ & $39.0 \%$ & $30.5 \%$ \\
\hline Min & $4.2 \%$ & $-0.9 \%$ & $6.7 \%$ & $1.8 \%$ \\
\hline
\end{tabular}


Table 3. Secondary school building: Annual energy savings and peak power reduction in 16 cities

\begin{tabular}{lccccc}
\hline & \multicolumn{2}{c}{ Annual power saving } & & \multicolumn{2}{c}{ Peak power reduction } \\
\cline { 2 - 3 } \cline { 5 - 6 } & $\begin{array}{c}\text { R410A } \\
\text { equipment }\end{array}$ & $\begin{array}{c}\text { R22 } \\
\text { equipment }\end{array}$ & & $\begin{array}{c}\text { R410A } \\
\text { equipment }\end{array}$ & $\begin{array}{c}\text { R22 } \\
\text { equipment }\end{array}$ \\
\hline Albuquerque, New Mexico & $18.8 \%$ & $6.7 \%$ & & $29.8 \%$ & $17.1 \%$ \\
Los Angeles, California & $6.8 \%$ & $0.7 \%$ & & $12.3 \%$ & $2.5 \%$ \\
Atlanta, Georgia & $9.3 \%$ & $3.0 \%$ & & $15.6 \%$ & $9.5 \%$ \\
Baltimore, Maryland & $9.5 \%$ & $3.4 \%$ & & $12.3 \%$ & $7.7 \%$ \\
Boulder, Colorado & $18.7 \%$ & $6.2 \%$ & & $31.2 \%$ & $17.9 \%$ \\
Chicago, Illinois & $9.9 \%$ & $3.2 \%$ & & $11.6 \%$ & $6.5 \%$ \\
Duluth, Minnesota & $9.4 \%$ & $2.2 \%$ & & $9.4 \%$ & $3.1 \%$ \\
Fairbanks, Alaska & $11.5 \%$ & $1.6 \%$ & & $20.2 \%$ & $6.4 \%$ \\
San Francisco, California & $10.5 \%$ & $2.0 \%$ & & $22.1 \%$ & $11.2 \%$ \\
Helena, Montana & $17.7 \%$ & $6.0 \%$ & & $25.2 \%$ & $14.4 \%$ \\
Houston, Texas & $8.3 \%$ & $3.0 \%$ & & $11.2 \%$ & $6.7 \%$ \\
Miami, Florida & $6.7 \%$ & $2.1 \%$ & & $9.5 \%$ & $4.8 \%$ \\
Minneapolis, Minnesota & $9.1 \%$ & $2.6 \%$ & & $10.8 \%$ & $4.8 \%$ \\
Phoenix, Arizona & $24.6 \%$ & $13.5 \%$ & & $31.7 \%$ & $25.2 \%$ \\
Seattle, Washington & $10.2 \%$ & $1.8 \%$ & & $14.8 \%$ & $5.5 \%$ \\
Las Vegas, Nevada & $26.9 \%$ & $14.4 \%$ & & $34.2 \%$ & $25.1 \%$ \\
\multicolumn{1}{c}{ Average } & $13.0 \%$ & $4.5 \%$ & & $18.9 \%$ & $10.5 \%$ \\
Max & $26.9 \%$ & $14.4 \%$ & & $34.2 \%$ & $25.2 \%$ \\
Min & $6.7 \%$ & $0.7 \%$ & & $9.4 \%$ & $2.5 \%$ \\
\hline
\end{tabular}


Table 4. Supermarket: Annual energy savings and peak power reduction in 16 cities

\begin{tabular}{lccccc}
\hline & \multicolumn{2}{c}{ Annual power saving } & & \multicolumn{2}{c}{ Peak power reduction } \\
\cline { 2 - 3 } \cline { 5 - 6 } & $\begin{array}{c}\text { R410A } \\
\text { equipment }\end{array}$ & $\begin{array}{c}\text { R22 } \\
\text { equipment }\end{array}$ & & $\begin{array}{c}\text { R410A } \\
\text { equipment }\end{array}$ & $\begin{array}{c}\text { R22 } \\
\text { equipment }\end{array}$ \\
\hline Albuquerque, New Mexico & $19.2 \%$ & $7.3 \%$ & & $26.2 \%$ & $16.0 \%$ \\
Los Angeles, California & $6.5 \%$ & $0.7 \%$ & & $8.1 \%$ & $2.7 \%$ \\
Atlanta, Georgia & $8.9 \%$ & $3.2 \%$ & & $20.7 \%$ & $13.4 \%$ \\
Baltimore, Maryland & $9.5 \%$ & $3.7 \%$ & & $12.2 \%$ & $6.0 \%$ \\
Boulder, Colorado & $18.7 \%$ & $6.6 \%$ & & $31.0 \%$ & $19.1 \%$ \\
Chicago, Illinois & $9.7 \%$ & $3.5 \%$ & & $18.1 \%$ & $11.0 \%$ \\
Duluth, Minnesota & $6.0 \%$ & $0.7 \%$ & & $15.2 \%$ & $7.1 \%$ \\
Fairbanks, Alaska & $6.5 \%$ & $-0.3 \%$ & & $17.4 \%$ & $8.0 \%$ \\
San Francisco, California & $9.9 \%$ & $1.9 \%$ & & $27.2 \%$ & $15.7 \%$ \\
Helena, Montana & $17.7 \%$ & $6.1 \%$ & & $32.1 \%$ & $18.6 \%$ \\
Houston, Texas & $9.1 \%$ & $4.1 \%$ & & $13.0 \%$ & $7.6 \%$ \\
Miami, Florida & $7.3 \%$ & $2.7 \%$ & & $10.4 \%$ & $4.9 \%$ \\
Minneapolis, Minnesota & $8.4 \%$ & $2.6 \%$ & & $10.7 \%$ & $5.8 \%$ \\
Phoenix, Arizona & $26.4 \%$ & $16.0 \%$ & & $37.0 \%$ & $29.4 \%$ \\
Seattle, Washington & $10.7 \%$ & $2.5 \%$ & & $28.3 \%$ & $18.4 \%$ \\
Las Vegas, Nevada & $28.8 \%$ & $16.7 \%$ & & $37.0 \%$ & $27.6 \%$ \\
Average & $12.7 \%$ & $4.9 \%$ & & $21.5 \%$ & $13.2 \%$ \\
Max & $28.8 \%$ & $16.7 \%$ & & $37.0 \%$ & $29.4 \%$ \\
Min & $6.0 \%$ & $-0.3 \%$ & & $8.1 \%$ & $2.7 \%$ \\
\hline
\end{tabular}

\subsection{WATER CONTROL STRATEGIES}

In Section 4.2.1 we stated that the pad surface temperature is a very weak function of the entering water temperature and hence water for pre-cooling may come from a variety of sources such as the city supply line, an underground source, rain water, or from a storage tank. The important point to remember is that the amount of water sprayed on the pad should be a small fraction of water that actually resides on the pad. In order to get the desired cooling and conserve water, equipment manufacturers have devised several water control strategies. Evaporcool ${ }^{\mathrm{TM}}$ (Evaporcool, 2010) uses a proprietary precision control process called SmartSpray ${ }^{\mathrm{TM}}$ to optimize efficiency and conserve water by automatically adjusting the water dispersion rate in response to changes in the weather and HVAC performance. With this system, Evaporcool ${ }^{\mathrm{TM}}$ states that one nozzle uses approximately $0.248 \mathrm{gal} / \mathrm{h}$ at conditions of $97.5^{\circ} \mathrm{F}, 30 \% \mathrm{RH}$, and $60 \mathrm{psi}$ supply water. The size of the condenser coil determines the number of nozzles required. A rooftop unit may have anywhere from 1 to 10 nozzles.

In our study, we demonstrate that condenser evaporative precooling is most efficient when ambient temperatures are high and relative humidity is low. So, an alternative way for saving water while still benefiting from evaporative pre-cooling is to turn on the water supply only at high ambient temperatures, although this strategy would not result in as much annual and peak energy reductions as would be the case if pre-cooling was deployed at all DB temperatures. 



\section{ECONOMICS}

The economics of condenser evaporative pre-cooling is driven by the climate, refrigerant, equipment vintage, utility rate structure, control strategy, and equipment costs. These factors are considered in our analysis of equipment. Since we are not privy to equipment cost structure, we relied on payback figures communicated to us from EVAPORCOOL. They provide systems for Carrier and Trane units. EVAPORCOOL reported (Elster) that the return on investment for their customers varies from 11 to 24 months depending on electrical rates, equipment conditions, climate, and level of customization of filter pad equipment.

\subsection{UTILITY RATE STRUCTURE}

The electricity rate structure for each city is complex because of the way electricity is distributed and the fact that more than one county may be included within a city. For example, in Atlanta, Georgia, there is a base charge and a metered charge. The base charge is a flat rate of $\$ 15.00$ plus a metered charge of $\$ 6.87$ per kilowatt (demand). For Seattle, Washington, the base rate is $\$ 0.71$ per meter per day plus a metered charge of $\$ 1.22$ per kilowatt (demand) for 50 $1000 \mathrm{~kW}$ (medium business) plus $\$ 0.06$ per kilowatt-hour consumed. For Phoenix, Arizona, the base charge is $\$ 0.672$ per day for self-contained meters plus $\$ 9.60$ per kilowatt for the first $100 \mathrm{~kW}$, plus $\$ 0.10$ per kilowatt-hour for the first $200 \mathrm{kWh}$ in May through October and $\$ 0.09$ per kilowatt-hour for the first $200 \mathrm{kWh}$ in November through April. In Houston, Texas, residents and businesses choose a transmission and distribution service provider who charges for "pass through" which includes actual usage plus kilowatt consumption. For Houston, the base rate is $\$ 7.90$ monthly plus $\$ 0.11 / \mathrm{kWh}$.

Because of the complex electricity rate structure, we utilized the figures published by the Energy Information Agency (EIA) (see Table 5). The economic analysis presented in the next section is developed from the utility rate structures described in this section. Highlighted values were the ones used in our analysis.

Water rates for seven cities are listed in Table 6 along with the sources from which the information was obtained. Like electricity, water rates have a complex structure.

\subsection{ANNUAL ELECTRICITY SAVINGS AND COST OF WATER}

In our analysis, savings are relative to the baseline equipment without pre-cooling. The variables in the relative savings analysis are the type of building, the pad wet bulb efficiency, the utility rates, the equipment COP and the type of refrigerant. Percent savings represents the annual operating cost savings with pre-cooling (taking into account the cost of water and pumping costs) relative to the cost of operating the same equipment without pre-cooling. One water conserving strategy is to use water for evaporative cooling only when the dry bulb temperature exceeds $90^{\circ} \mathrm{F}\left(32.2^{\circ} \mathrm{C}\right)$ instead of using it at all temperatures during the cooling season. We examine this option as well. Our findings are summarized below. 
Table 5. Electric rates in various cities

\begin{tabular}{|c|c|c|c|c|c|c|c|c|c|c|}
\hline \multirow{3}{*}{$\begin{array}{c}\text { Census division } \\
\text { and state }\end{array}$} & \multicolumn{10}{|c|}{$\begin{array}{l}\text { Average retail price of electricity to ultimate customers by end-use sector } \\
\text { (cents per kilowatt-hour) }\end{array}$} \\
\hline & \multicolumn{2}{|c|}{ Residential } & \multicolumn{2}{|c|}{ Commercial } & \multicolumn{2}{|c|}{ Industrial } & \multicolumn{2}{|c|}{ Transportation } & \multicolumn{2}{|c|}{ All sectors } \\
\hline & $\begin{array}{l}\text { May } \\
2010\end{array}$ & $\begin{array}{l}\text { May } \\
2009\end{array}$ & $\begin{array}{l}\text { May } \\
2010\end{array}$ & $\begin{array}{l}\text { May } \\
2009\end{array}$ & $\begin{array}{l}\text { May } \\
2010\end{array}$ & $\begin{array}{l}\text { May } \\
2009\end{array}$ & $\begin{array}{l}\text { May } \\
2010\end{array}$ & $\begin{array}{l}\text { May } \\
2009\end{array}$ & $\begin{array}{l}\text { May } \\
2010\end{array}$ & $\begin{array}{l}\text { May } \\
2009\end{array}$ \\
\hline New England & 16.53 & 17.92 & 14.48 & 14.93 & 12.5 & 13.21 & 8.43 & 7.04 & 14.66 & 15.48 \\
\hline Connecticut & 20.08 & 21.08 & 16.7 & 16.49 & 14.36 & 16.28 & 13.29 & 10.76 & 17.67 & 18.19 \\
\hline Maine & 15.48 & 15.19 & 12.11 & 11.92 & 8.4 & 9.25 & -- & -- & 12.02 & 12.21 \\
\hline Massachusetts & 15.04 & 17.72 & 14.17 & 15.07 & 13.38 & 13.76 & 5.98 & 5.2 & 14.14 & 15.41 \\
\hline New Hampshire & 16.36 & 16.59 & 13.93 & 15.15 & 12.43 & 13.7 & -- & -- & 14.56 & 15.42 \\
\hline Rhode Island & 15.2 & 14.91 & 12.32 & 13.24 & 11.91 & 12.15 & 12.07 & -- & 13.32 & 13.56 \\
\hline Vermont & 15.7 & 15.08 & 13.51 & 13.05 & 9.25 & 9.05 & -- & -- & 13.13 & 12.73 \\
\hline Middle Atlantic & 16.16 & 14.94 & 13.87 & 12.85 & 8.46 & 8.39 & 13.02 & 13.04 & 13.53 & 12.64 \\
\hline New Jersey & 16.13 & 16.17 & 13.66 & 13.77 & 11.59 & 11.64 & 12.52 & 12.3 & 14.27 & 14.23 \\
\hline New York & 19.1 & 17.22 & 16.32 & 14.26 & 9.58 & 10.86 & 14.92 & 14.42 & 16.49 & 14.91 \\
\hline Pennsylvania & 13.4 & 12.05 & 10.21 & 9.84 & 7.59 & 6.95 & 7.46 & 8.72 & 10.33 & 9.59 \\
\hline East North Central & 11.8 & 11.47 & 9.15 & 9.08 & 6.47 & 6.8 & 6.71 & 9.29 & 9.01 & 9.04 \\
\hline Illinois & 11.96 & 12.13 & 7.94 & 8.33 & 7.48 & 7.37 & 6.46 & 8.94 & 9.05 & 9.24 \\
\hline Indiana & 9.98 & 10.04 & 8.24 & 8.28 & 5.71 & 5.78 & 10.1 & 9.77 & 7.49 & 7.62 \\
\hline Michigan & 12.84 & 11.98 & 10.64 & 9.6 & 7.29 & 7.86 & 10.88 & 10.87 & 10.23 & 9.82 \\
\hline Ohio & 11.68 & 11.21 & 9.81 & 10 & 6.19 & 6.97 & 9.66 & 12.72 & 8.95 & 9.26 \\
\hline Wisconsin & 12.71 & 12.02 & 9.82 & 9.41 & 6.56 & 6.6 & -- & -- & 9.5 & 9.15 \\
\hline West North Central & 10.05 & 9.57 & 7.84 & 7.43 & 5.61 & 5.64 & 6.57 & 6.72 & 7.79 & 7.58 \\
\hline Iowa & 11.03 & 10.26 & 7.75 & 7.28 & 5.11 & 4.86 & -- & -- & 7.42 & 6.99 \\
\hline Kansas & 10.34 & 9.91 & 8.24 & 7.98 & 6.11 & 6.22 & -- & -- & 8.18 & 8.07 \\
\hline Minnesota & 10.45 & 10.17 & 8.13 & 7.68 & 5.81 & 6.27 & 7.74 & 7.66 & 7.97 & 8.03 \\
\hline Missouri & 9.79 & 9.27 & 7.69 & 7.15 & 5.32 & 5.38 & 5.13 & 5.56 & 7.88 & 7.55 \\
\hline Nebraska & 9.14 & 8.69 & 7.6 & 7.31 & 5.73 & 5.57 & -- & -- & 7.36 & 7.11 \\
\hline North Dakota & 8.49 & 8.28 & 7.1 & 6.98 & 6.25 & 5.93 & -- & -- & 7.21 & 7.07 \\
\hline South Dakota & 9.34 & 8.86 & 7.59 & 7.2 & 5.99 & 5.67 & -- & -- & 7.88 & 7.49 \\
\hline South Atlantic & 11.21 & 11.34 & 9.28 & 9.6 & 6.45 & 6.64 & 9.81 & 13.14 & 9.48 & 9.76 \\
\hline Delaware & 14.81 & 14.75 & 11.49 & 12.51 & 9.45 & 9.18 & 7.39 & -- & 12.1 & 12.39 \\
\hline District of Columbia & 13.58 & 12.72 & 14 & 13.6 & 8.4 & 9 & 10.64 & 19.11 & 13.73 & 13.52 \\
\hline Florida & 11.56 & 12.18 & 9.96 & 10.7 & 8.6 & 9.17 & 9.07 & 10.56 & 10.63 & 11.3 \\
\hline Georgia & 10.26 & 9.94 & 8.89 & 8.64 & 5.86 & 5.89 & 7.64 & 6.75 & 8.6 & 8.46 \\
\hline Maryland & 14.6 & 15.03 & 11.42 & 12.47 & 9.36 & 10.24 & 10.77 & 13.59 & 12.44 & 13.19 \\
\hline North Carolina & 10.4 & 10.13 & 8.08 & 7.75 & 6.03 & 5.77 & 7.18 & 6.81 & 8.45 & 8.23 \\
\hline South Carolina & 10.55 & 10.36 & 8.59 & 8.46 & 5.49 & 5.81 & -- & -- & 8.07 & 8.19 \\
\hline Virginia & 10.83 & 11.11 & 7.67 & 8.32 & 6.67 & 6.97 & 7.79 & 8.74 & 8.6 & 9.1 \\
\hline West Virginia & 8.92 & 8.06 & 7.63 & 6.82 & 5.73 & 5.44 & 8.71 & 7.41 & 7.23 & 6.68 \\
\hline East South Central & 9.93 & 9.79 & 9.34 & 9.18 & 5.77 & 5.86 & 11.81 & 11.18 & 8.04 & 8.08 \\
\hline Alabama & 11.03 & 10.44 & 10.37 & 9.7 & 6.1 & 5.98 & -- & -- & 8.85 & 8.59 \\
\hline Kentucky & 8.67 & 8.51 & 7.72 & 7.47 & 5 & 4.86 & -- & -- & 6.49 & 6.4 \\
\hline Mississippi & 10.58 & 10.61 & 9.51 & 9.7 & 6.29 & 6.72 & -- & -- & 8.7 & 8.99 \\
\hline Tennessee & 9.49 & 9.68 & 9.58 & 9.71 & 6.4 & 6.81 & 11.81 & 11.18 & 8.51 & 8.78 \\
\hline
\end{tabular}


Table 5. (continued)

\begin{tabular}{|c|c|c|c|c|c|c|c|c|c|c|}
\hline \multirow{3}{*}{$\begin{array}{l}\text { Census division } \\
\text { and state }\end{array}$} & \multicolumn{10}{|c|}{$\begin{array}{l}\text { Average retail price of electricity to ultimate customers by end-use sector } \\
\text { (cents per kilowatt-hour) }\end{array}$} \\
\hline & \multicolumn{2}{|c|}{ Residential } & \multicolumn{2}{|c|}{ Commercial } & \multicolumn{2}{|c|}{ Industrial } & \multicolumn{2}{|c|}{ Transportation } & \multicolumn{2}{|c|}{ All sectors } \\
\hline & $\begin{array}{l}\text { May } \\
2010\end{array}$ & $\begin{array}{l}\text { May } \\
2009\end{array}$ & $\begin{array}{l}\text { May } \\
2010\end{array}$ & $\begin{array}{l}\text { May } \\
2009\end{array}$ & $\begin{array}{l}\text { May } \\
2010\end{array}$ & $\begin{array}{l}\text { May } \\
2009\end{array}$ & $\begin{array}{l}\text { May } \\
2010\end{array}$ & $\begin{array}{l}\text { May } \\
2009\end{array}$ & $\begin{array}{l}\text { May } \\
2010\end{array}$ & $\begin{array}{l}\text { May } \\
2009\end{array}$ \\
\hline West South Central & 11.33 & 11.66 & 8.93 & 9.04 & 6.06 & 6.27 & 9.99 & 9.81 & 8.85 & 9.18 \\
\hline Arkansas & 9.52 & 9.41 & 7.55 & 7.23 & 5.38 & 5.7 & 11.44 & 13.74 & 7.27 & 7.44 \\
\hline Louisiana & 9.12 & 8.66 & 8.43 & 8.06 & 5.66 & 5.65 & 8.86 & 9.28 & 7.62 & 7.42 \\
\hline Oklahoma & 10.15 & 8.77 & 7.35 & 6.45 & 5.21 & 4.9 & -- & -- & 7.68 & 6.83 \\
\hline Texas & 12.22 & 13 & 9.45 & 9.86 & 6.44 & 6.77 & 10.17 & 9.85 & 9.53 & 10.18 \\
\hline Mountain & 10.92 & 10.37 & 9.23 & 8.67 & 5.98 & 5.9 & 9.73 & 8.17 & 8.73 & 8.38 \\
\hline Arizona & 11.76 & 11.34 & 10.11 & 9.78 & 6.9 & 7.06 & -- & -- & 10.22 & 10.05 \\
\hline Colorado & 11.52 & 9.7 & 9.58 & 7.95 & 7.07 & 5.97 & 9.94 & 7.37 & 9.5 & 7.97 \\
\hline Idaho & 8.03 & 7.36 & 6.9 & 6.28 & 5.18 & 4.86 & -- & -- & 6.54 & 6 \\
\hline Montana & 9.1 & 8.98 & 8.39 & 8.13 & 5.5 & 5.73 & -- & -- & 7.49 & 7.43 \\
\hline Nevada & 12.93 & 12.46 & 10.56 & 10.42 & 6.37 & 7.14 & 8.74 & 9.53 & 9.38 & 9.69 \\
\hline New Mexico & 10.5 & 9.61 & 8.65 & 8.18 & 5.77 & 5.56 & -- & -- & 8.21 & 7.74 \\
\hline Utah & 8.85 & 8.58 & 7.64 & 7.32 & 4.97 & 4.82 & 9.68 & 8.84 & 7.09 & 6.86 \\
\hline Wyoming & 8.82 & 8.9 & 7.55 & 7.49 & 4.87 & 4.79 & -- & -- & 6.13 & 6.04 \\
\hline Pacific Contiguous & 12.6 & 12.48 & 11.88 & 11.85 & 7.63 & 7.75 & 8.01 & 7.85 & \begin{tabular}{|l|l|}
11.12 \\
\end{tabular} & 11.16 \\
\hline California & 15.43 & 15.24 & 13.65 & 13.6 & 10.41 & 10.03 & 8.05 & 7.88 & 13.55 & 13.42 \\
\hline Oregon & 9.04 & 8.84 & 7.84 & 7.63 & 5.87 & 5.79 & 7.04 & 6.74 & 7.78 & 7.59 \\
\hline Washington & 8.15 & 7.76 & 7.26 & 6.96 & 3.73 & 4.04 & 6.36 & 6.17 & 6.5 & 6.48 \\
\hline Pacific Noncontiguous & 23.93 & 20.4 & 21.14 & 17.59 & 20.28 & 15.03 & -- & -- & 21.71 & 17.64 \\
\hline Alaska & 16.97 & 17.67 & 14.73 & 15.1 & 14.75 & 12.78 & -- & -- & 15.45 & 15.39 \\
\hline Hawaii & 28.25 & 22.04 & 26.14 & 19.52 & 22.11 & 15.81 & -- & -- & 25.25 & 18.92 \\
\hline U.S. Total & 11.96 & 11.8 & 10.19 & 10.08 & 6.69 & 6.86 & 10.85 & 11.64 & 9.8 & 9.83 \\
\hline
\end{tabular}

Source: DOE/EIA-0226, released August 11, 2010. Next release date, mid-September 2010. 
Table 6. Water rates in seven cities

\begin{tabular}{|c|c|c|c|c|c|c|}
\hline \multirow{2}{*}{ City } & \multicolumn{2}{|c|}{ Water } & \multicolumn{2}{|c|}{ Sewer/Wastewater } & \multirow{2}{*}{ Notes } & \multirow{2}{*}{ Source } \\
\hline & Base charge & Metered charge & Base charge & Metered charge & & \\
\hline Albuquerque & & $\$ 1.41$ per unit & $a$ & & $\begin{array}{l}1 \text { unit = } 748 \text { gal; on- } \\
\text { peak = M-F } 8 \text { a.m. to } \\
8 \text { p.m.; off-peak = all } \\
\text { other hours }\end{array}$ & \\
\hline Atlanta & \$5.86 monthly & $\begin{array}{l}\$ 2.30 \text { per } 1-3 \mathrm{ccf} ; \\
\$ 4.77 \text { per } 4-6 \mathrm{ccf} ; \\
\$ 5.50 \text { per } \geq 7 \mathrm{ccf}\end{array}$ & $a$ & & $\begin{array}{l}1 \mathrm{ccf}=100 \text { cubic ft } \\
\text { water or } 750 \text { gal; a } \\
\text { business is medium } \\
\text { sized if demanding } \\
\geq 30 \mathrm{~kW}\end{array}$ & $\begin{array}{l}\text { www.atlantawatershed. } \\
\text { org/custsrv/water_and_ } \\
\text { sewer_rates.htm }\end{array}$ \\
\hline Houston & $\begin{array}{l}\$ 5.59 \text { monthly for } 1 \text { in. } \\
\text { meter, } \$ 8.46 \text { monthly } \\
\text { for } 1 \frac{1}{2} \text { in. meter }\end{array}$ & \$3.56 per 1000 gal & $\begin{array}{l}\$ 8.33 \text { monthly for } 1 \text { in. } \\
\text { meter; } \$ 9.66 \text { monthly } \\
\text { for } 1 \frac{1}{2} \text { in. meter }\end{array}$ & $\$ 5.04$ per 1000 gal & & $\begin{array}{l}\text { Phone 972-507-9501; } \\
\text { documents.publicwork } \\
\text { s.houstontx.gov/ } \\
\text { documents/divisions/ } \\
\text { resource/ucs/june_201 } \\
\text { 0_water_rates.pdf }\end{array}$ \\
\hline Minneapolis & & \$3.05 per unit & \$2.93 per unit & & & \\
\hline Phoenix & $\begin{array}{l}\text { Monthly base rate } \\
\text { includes six units of } \\
\text { water for October } \\
\text { through May, and ten } \\
\text { units of water for June } \\
\text { through September. } \\
\$ 4.49 \text { monthly for } 1 \text { in. } \\
\text { meter, } \$ 5.57 \text { monthly } \\
\text { for } 1 \frac{1}{2} \text { in. meter }\end{array}$ & $\begin{array}{l}\text { Per unit charges (for } \\
\geq 11 \text { ): \$2.18 in Dec, } \\
\text { Jan, Feb, Mar; \$2.69 in } \\
\text { Apr, May, Oct, Nov; } \\
\$ 3.51 \text { in Jun, Jul, Aug, } \\
\text { Sep; “environmental } \\
\text { charge” of \$0.40 per } \\
\text { unit pays for safe } \\
\text { drinking water testing, } \\
\text { etc. }\end{array}$ & & $\begin{array}{l}\text { Sewage rates are based } \\
\text { on winter months' } \\
\text { water use, see } \\
\text { phoenix.gov/WATER/ } \\
\text { swrratesch.pdf }\end{array}$ & $\begin{array}{l}1 \text { unit = } 748 \text { gal; } \\
\text { medium-sized business } \\
\text { is defined as } \\
\text { demanding } 101- \\
400 \mathrm{~kW} \text {; Phoenix } \\
\text { electricity provided by } \\
\text { either APS or SRP } \\
\text { (rates here are APS) }\end{array}$ & $\begin{array}{l}\text { phoenix.gov/waterservi } \\
\text { ces/customerservices/p } \\
\text { ayment/rates/ } \\
\text { index.html; } \\
\text { phoenix.gov/WATER/s } \\
\text { wrratesch.pdf; } \\
\text { www.aps.com/ } \\
\text { main/services/business/ } \\
\text { rates/BusRatePlans_13. } \\
\text { html\#medtou }\end{array}$ \\
\hline San Francisco & & & & & $\begin{array}{l}1 \mathrm{ccf}=100 \text { cubic } \mathrm{ft} \\
\text { water or } 748 \mathrm{gal}\end{array}$ & \\
\hline Seattle & $\begin{array}{l}\$ 13.00 \text { monthly for } \\
1 \text { in. meter; } \$ 19.95 \\
\text { monthly for } 1 \frac{1}{2} \text { in. } \\
\text { meter }\end{array}$ & $\begin{array}{l}\text { \$3.50 per ccf during } \\
\text { 9/16-5/15; \$4.49 per } \\
\text { ccf during 5/16-9/15 }\end{array}$ & $\$ 8.98$ per ccf & & & $\begin{array}{l}\text { Phone 206-684-3000; } \\
\text { "Medium General } \\
\text { Service-Seattle" at } \\
\text { www.seattle.gov/light/ } \\
\text { Accounts/Rates/ } \\
\text { ac5_erps20_1.htm }\end{array}$ \\
\hline
\end{tabular}

${ }^{a}$ If blank, sewage is included in water rate. 
If pre-cooling is deployed at all ambient temperatures during the cooling season, then the percent energy savings relative to using no pre-cooling at wet bulb efficiency of 0.7 and equipment COP of 3.0 is shown in Fig. 17. It should be mentioned that COP used here refers to the outdoor unit, which considers total cooling capacity and compressor and outdoor fan power consumptions. The indoor blower power and heat are not taken into consideration. This is in line with EnergyPlus input. The COP of 3.0 represents lower efficiency equipment used in current commercial buildings. We observe that annual operating cost savings are increased due to precooling for all three types of buildings particularly in the hot dry climates (Phoenix, Albuquerque) but less pronounced in wet climates (Seattle), and that cost savings with R410A are significantly greater than it is for the older R22 refrigerant. Hot dry climates are amenable to water evaporation and hence such climates benefit from this technology. For the same wet bulb efficiency and COP, the percent savings if pre-cooling is deployed when the wet bulb temperature exceeds $90^{\circ} \mathrm{F}$ is shown in Fig. 18 for comparison with Fig. 17.

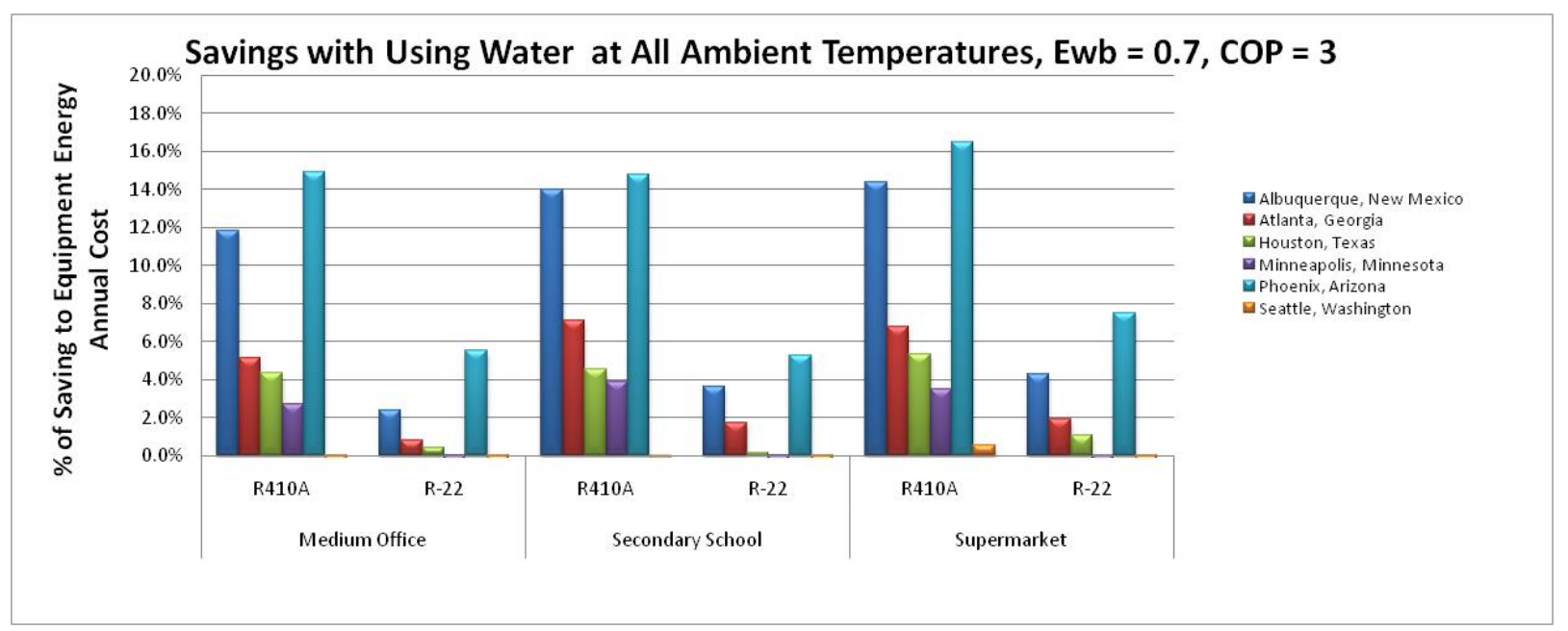

Fig. 17. Percentage of energy savings due to pre-cooling relative to no pre-cooling when water is sprayed at all ambient temperatures and wet bulb efficiency of 0.7 , and COP $=3$.

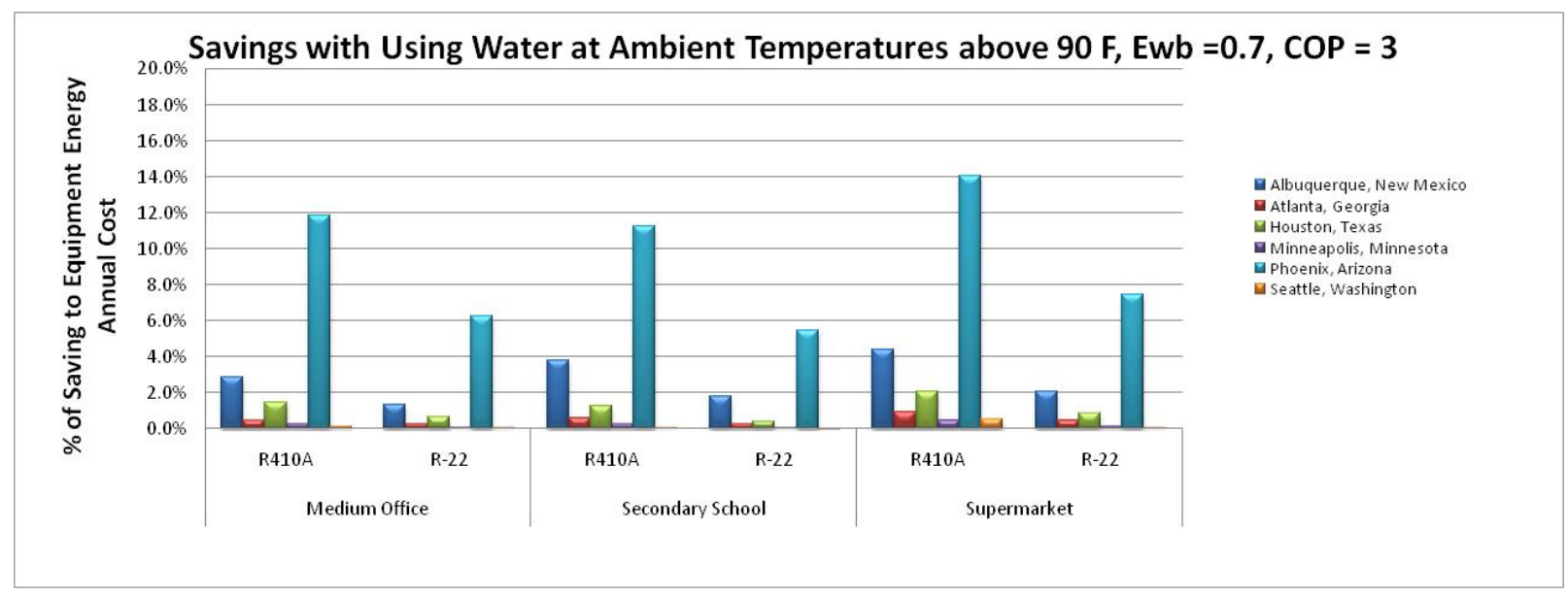

Fig. 18. Percentage of energy savings due to pre-cooling relative to no pre-cooling when water is sprayed after ambient temperature equals or exceeds $90^{\circ} \mathbf{F}$. Wet bulb efficiency $=0.7, \mathrm{COP}=3$. 
Here we observe that, for equipment using R-410A, if precooling is deployed only when the ambient air temperature exceeds $90^{\circ} \mathrm{F}$, the percent operating cost savings are less than if precooling was deployed at all operating temperatures in the respective climates. However, the results are different for equipment using R-22 as shown by Fig. 17 and Fig. 18. For example, for the medium office in Phoenix, AZ, spraying water at all temperatures yields an annual relative cost saving of $5.5 \%$, whereas spraying water only when the DB is above $90^{\circ} \mathrm{F}$, yields a slightly higher annual cost saving of 6.3\%. Similar conclusions are reached for the secondary school and supermarket. Therefore, for R22, it may be beneficial to use water only when DB temperatures exceed $90^{\circ} \mathrm{F}$ to maximize the annual operating cost savings while simultaneously minimizing water use. However, it must be pointed out clearly that the annual and peak energy reductions using R410A are far greater than that of using R22, and for R410A the savings are greater if the equipment is operated at all DB temperatures rather than only when the DB exceeds $90^{\circ} \mathrm{F}$.

Manufacturer's data extends up to wet bulb efficiency of 99\%. In our EnergyPlus simulations, we consider an upper wet bulb efficiency limit of 0.9 ; the results for this case are shown in Figs. 19 and 20.

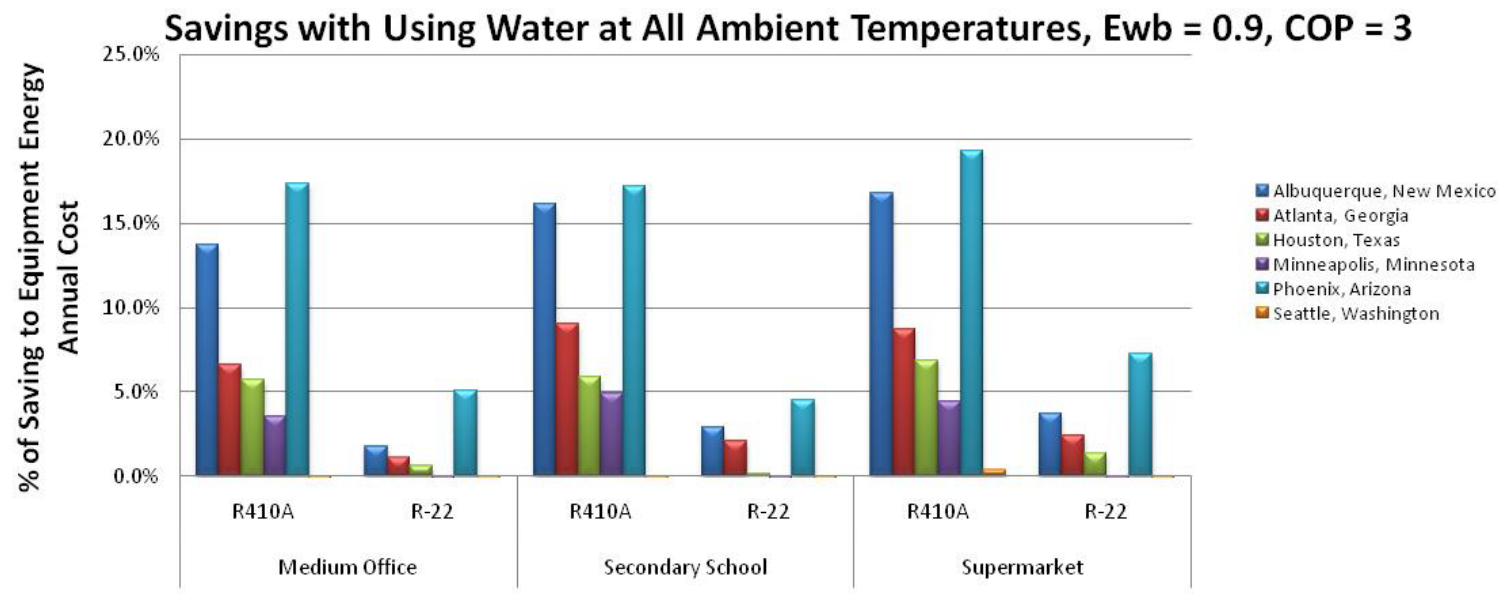

Fig. 19. Percentage of energy savings due to pre-cooling relative to no pre-cooling at all ambient temperatures. Wet bulb efficiency $=0.9$, equipment $\mathrm{COP}=3$.

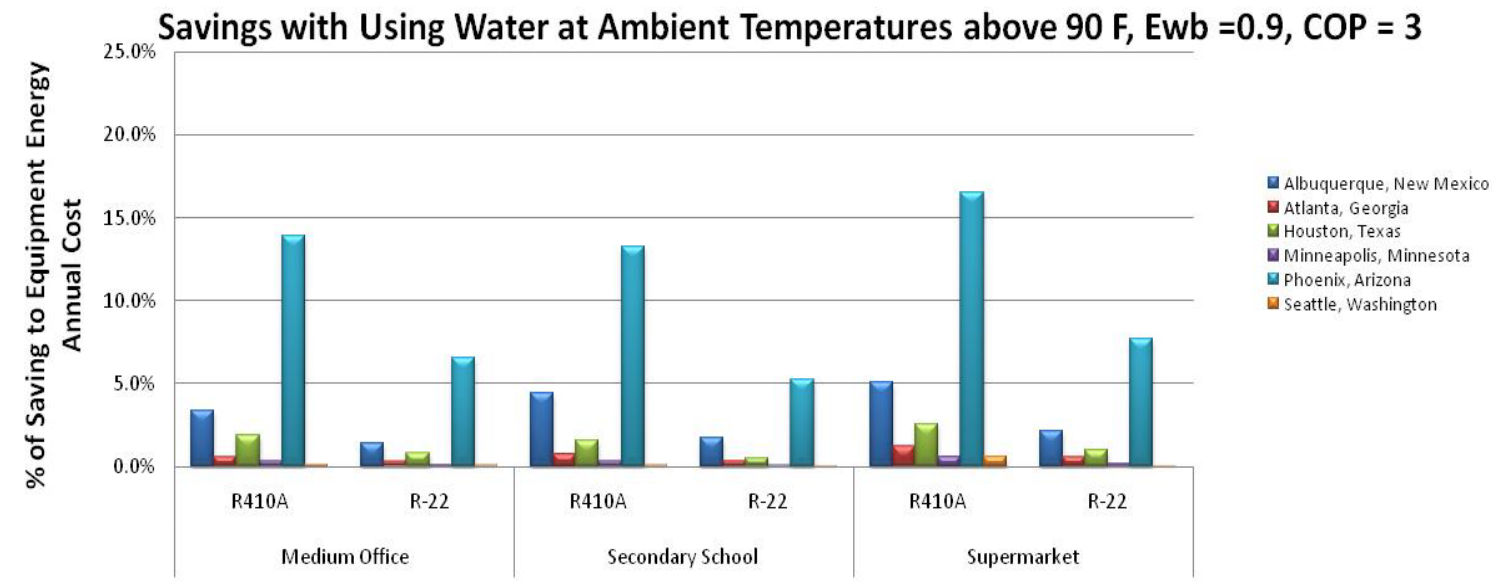

Fig. 20. Percentage of energy savings due to pre-cooling relative to no pre-cooling when water is sprayed after ambient temperature is equal to or exceeds $90^{\circ} \mathbf{F}$. Wet bulb efficiency $=0.9$, equipment $\mathrm{COP}=3$. 
Again we see significantly higher annual operating cost savings using R410A versus R22 for the three building types in all six cities except Seattle, for the reasons mentioned above, and that increasing the wet bulb efficiency from 0.7 to 0.9 marginally improves the annual operating cost savings as seen by comparing Fig. 17 and Fig. 19. If precooling is deployed only when the ambient temperature exceeds $90^{\circ} \mathrm{F}$, annual percent savings using R-410A equipment drop slightly, but the annual percent savings using R-22 equipment increase slightly.

Next, we examine the effect of installing a more efficient rooftop unit with a $\mathrm{COP}=5$, which represents the higher efficiency level of equipment on the market, to replace an older rooftop unit and make the same comparisons described above.

As expected, the impact on annual energy savings with precooling as compared to no precooling in more efficient equipment $(\mathrm{COP}=5)$ is smaller than it would be for a less efficient equipment $(\mathrm{COP}=3)$ as shown by comparison of Fig. 17 with Fig. 21.

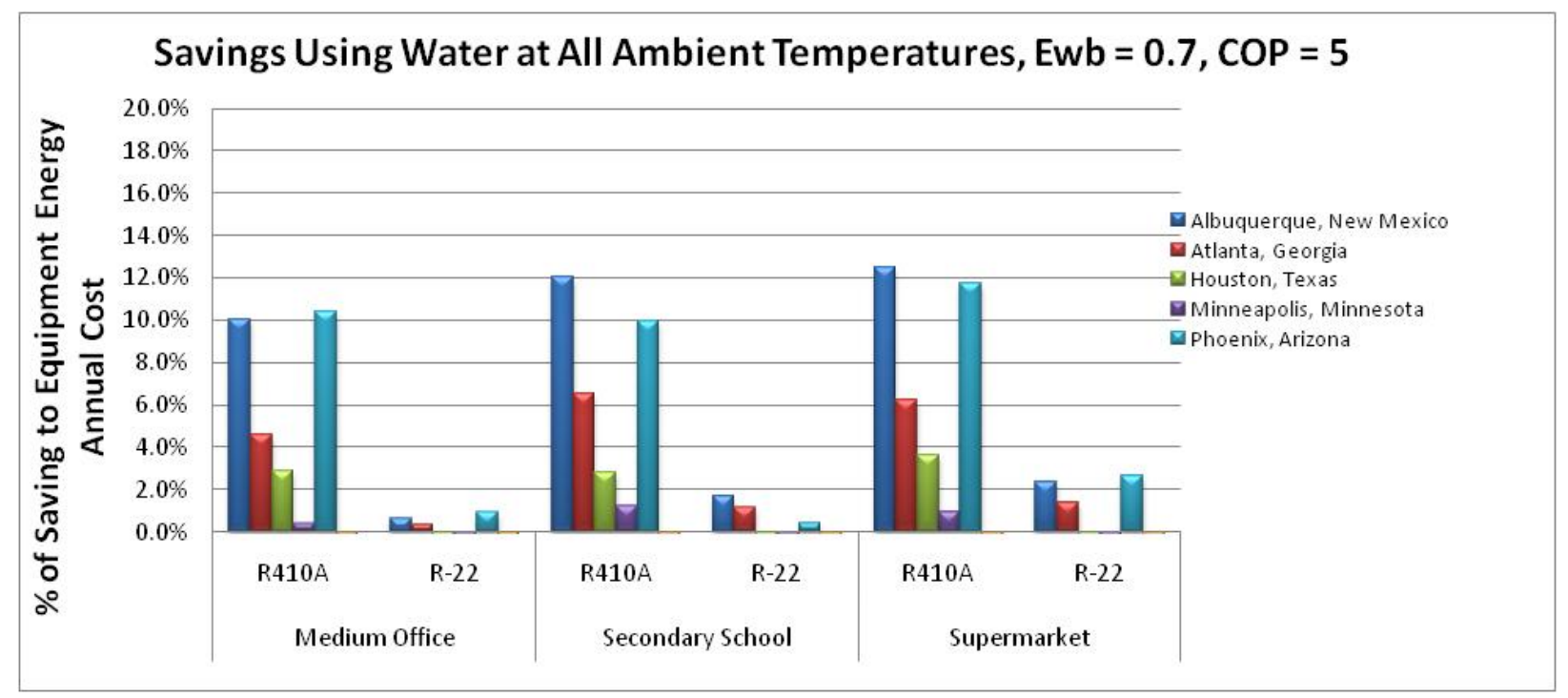

Fig. 21. Percentage of savings due to pre-cooling relative to no pre-cooling at all ambient temperatures. Wet bulb efficiency $=0.7$, equipment $\mathrm{COP}=5$.

A similar trend is observed at higher wet bulb efficiency of 0.9 , as shown by comparing Fig. 19 and Fig. 22. The impact of pre-cooling on annual savings compared to no pre-cooling is attenuated for equipment that operate at high efficiency (COP = 5 compared to COP $=3$ ), but nonetheless, pre-cooling does provide energy savings, especially in hot, dry climates.

Comparing the annual energy savings estimates for the higher efficient $(\mathrm{COP}=5)$ equipment that utilizes a water control strategy of deploying pre-cooling only when the DB temperature exceeds $90^{\circ} \mathrm{F}$, we find similar trends as discussed for the lower efficiency equipment $(\mathrm{COP}=3)$. For equipment using R-410A, when pre-cooling is deployed at DB temperatures exceeding $90^{\circ} \mathrm{F}$ (Fig. 23), annual operating cost savings are somewhat lower than if pre-cooling is deployed at all DB temperatures (Fig. 21). The same trend is observed at the higher WB efficiency of 0.9 (Fig. 22 compared against Fig. 23). Therefore, at least for these three building types, the recommended modus operandi would be to pre-cool at all DB temperatures, for equipment using R-410A. On the other hand, for equipment using R-22 in the cities where the water price is high, we recommend applying pre-cooling at higher ambient temperatures (for example when DB exceeds $90^{\circ} \mathrm{F}$ ) at the discretion of the operator. 


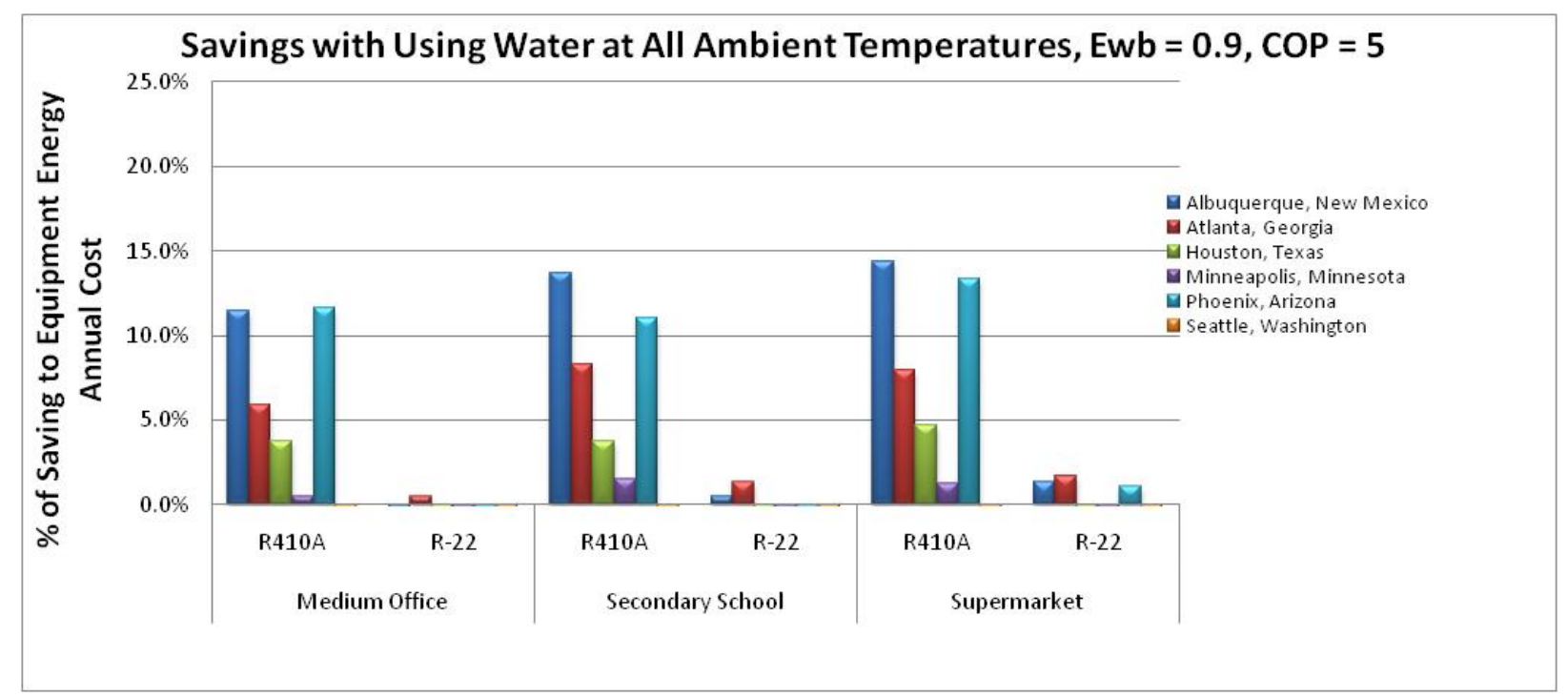

Fig. 22. Percentage of energy savings due to pre-cooling relative to no pre-cooling at all ambient temperatures. Wet bulb efficiency $=0.9$, equipment $\mathrm{COP}=5$.

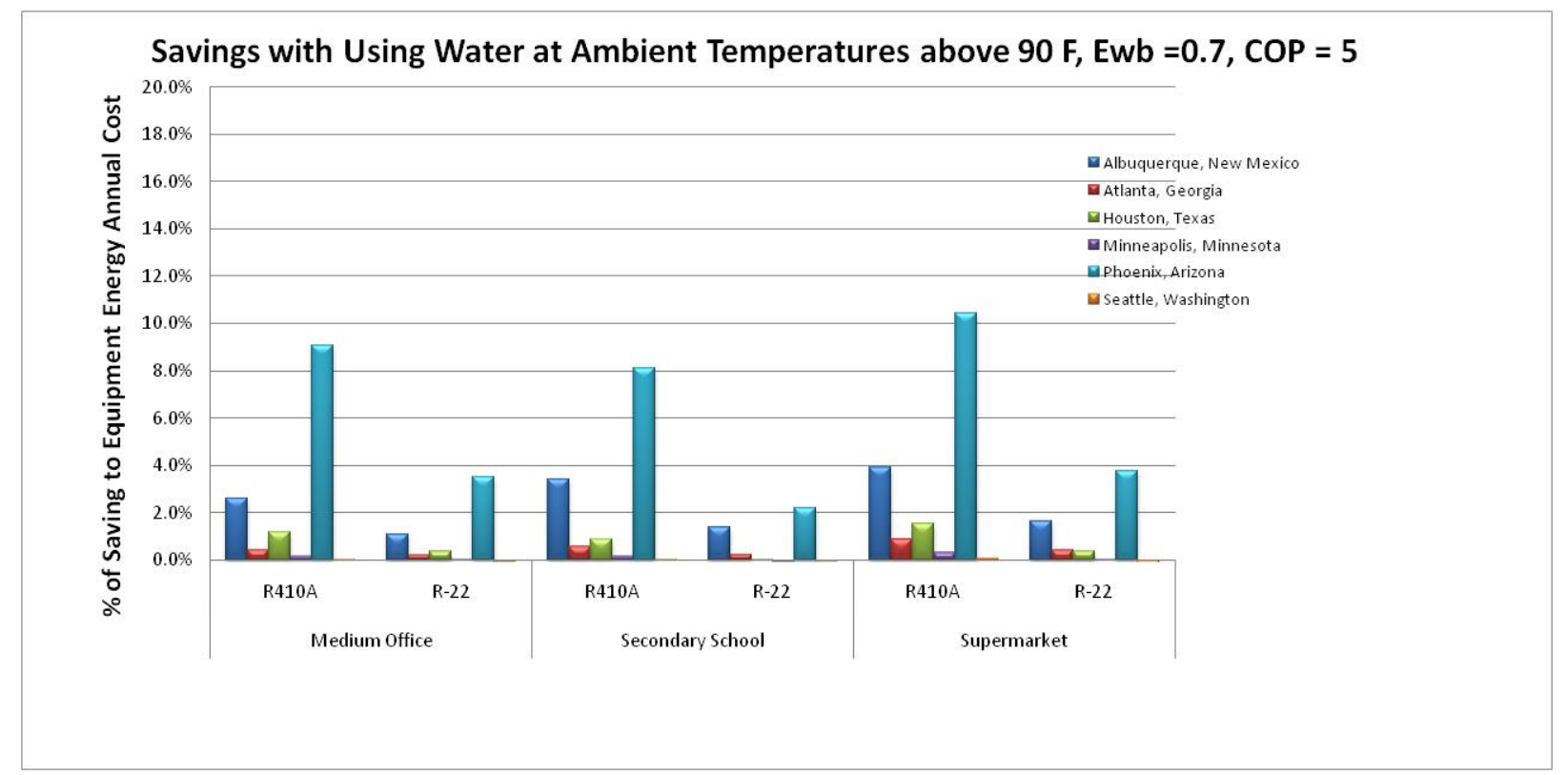

Fig. 23. Percentage of energy savings due to pre-cooling relative to no pre-cooling when water is sprayed after ambient temperature is equal to or exceeds $90^{\circ} \mathrm{F}$. Wet bulb efficiency $=0.9$, equipment $\mathrm{COP}=5$. 


\section{CONCLUSIONS}

- Evaporative cooling expands the availability of energy saving, cost-effective technology options (market engagement) and serves to broaden the range of options in upcoming codes and equipment standards (impacting regulation). Commercially available evaporative precoolers provide a low cost retrofit for many existing packaged rooftop units, commercial unitary split systems, and air cooled chillers.

- Energy savings are much greater for HVAC systems with refrigerant R410A than they are with R22.

- For R-410A equipment, operating cost percent savings are greater if pre-cooling is used at all DB temperatures than they are if used only when the DB temperature exceeds $90^{\circ} \mathrm{F}$. For $\mathrm{R}-22$ equipment in the cities where the water price is high, we would recommend applying pre-cooling only at high ambient temperatures.

- Evaporative pre-cooling provides the opportunity for annual energy savings and peak demand reduction, with significant potential in hot, dry climates. 


\section{RECOMMENDATIONS}

Our analyses are based on three building types in 16 locations across the United States. In order to gain a comprehensive picture of the energy and peak demand reduction potential of this technology, this study should be expanded to 16 building types in all 16 locations mentioned in a recent report (P. Torcellini, 2008). Such a comprehensive study has not been undertaken, but this report has laid the necessary foundation for such a comprehensive analysis.

Furthermore, it is possible to develop a software design tool for condenser evaporative precooling. This tool will provide a pad wet bulb efficiency estimate based on the real media geometry and frontal air velocity. In addition, if the recommended comprehensive analysis is conducted, a separate estimator could be developed to provide estimates of annual energy saving, peak power reduction, operating cost savings and recommended control strategy, pad design, etc for applying the evaporative pre-cooling to a specific building, equipment, and climate. This tool could be web-based or freely available software, to serve as design guidance to promote deployment of condenser evaporative pre-cooling technology.

Evaporative pre-cooling technology can potentially reduce HVAC energy consumption in existing commercial building stock, thereby impacting a very large commercial market segment with a single technology. It meets both key elements of the Commercial Building Integration and Deployment (CBID) subprogram of market engagement and impacting regulation. Evaporative pre-coolers are specifically designed to retrofit existing units on-site. 


\section{BIBLIOGRAPHY}

Braun, J. E., S. A. Klein, and J. W. Mitchell. 1989. Effectiveness models for cooling towers and cooling coils. ASHRAE Transactions, 95(2), 164-174.

Elster, M. S. Various dates. Personal Communications with M. R. Ally.

Evaporcool. 2010. Retrieved from http://www.evaporcool.com/howitworks.html.

Torcellini, P. 2008. DOE Commercial Building Benchmark Models. National Renewable Energy Laboratory. NREL/CP-550-43291

Warke, K. J. 1995. Advanced Thermodynamics for Engineering. Mc-Graw-Hill.

Wu, J. M., X. Huang, and H. Zhang. 2009b. Numerical investigation on the heat and mass transfer in a direct evaporative cooler. Applied Thermal Engineering, 29, 195-201.

Wu, J. M., X. Huang, and H. Zhang. 2009a. Theoretical analysis on heat and mass transfer in a direct evaporative cooler. Applied Thermal Engineering, 29, 980-984.

DOE Commercial Benchmark Buildings, http://www1.eere.energy.gov/buildings/commercial_initiative/reference_buildings.html 

APPENDIXES 



\section{APPENDIX A. EQUIPMENT CURVES IN ENERGYPLUS}

We used EnergyPlus 5.0 to conduct the simulation study, which is the latest DOE building energy simulation software. In EnergyPlus, rooftop DX air conditioners are given in the form of performance curves, which correct the equipment performances from the rating point at the ambient condition of $35^{\circ} \mathrm{C}$ dry bulb temperature, $19.4^{\circ} \mathrm{C}$ wet bulb temperature $\left(80^{\circ} \mathrm{F} / 67^{\circ} \mathrm{F}\right)$ and nominal indoor air flow rates. The equation forms are given as below,

$$
\begin{gathered}
\dot{Q}_{\text {total }}=\dot{Q}_{\text {total }, \text { rated }}(\text { TotCapTempModFac })(\text { TotCapFlowModFac }) \\
\text { Power }=\left(\dot{Q}_{\text {total }, \text { rated }}\right)(\text { EIR })(\text { RTF }) \\
\text { EIR }=\left(\frac{1}{\text { COP }_{\text {rated }}}\right)(\text { EIRTempModFac })(\text { EIRFlowModFac }) \\
\text { TotCapTempModFac }=a+b\left(T_{w b, i}\right)+c\left(T_{w b, i}\right)^{2}+d\left(T_{c, i}\right)+e\left(T_{c, i}\right)^{2}+f\left(T_{w b, i}\right)\left(T_{c, i}\right) \\
\text { EIRCapTempModFac }=a+b\left(T_{w b, i}\right)+c\left(T_{w b, i}\right)^{2}+d\left(T_{c, i}\right)+e\left(T_{c, i}\right)^{2}+f\left(T_{w b, i}\right)\left(T_{c, i}\right) \\
\text { TotCapFlowModFac }=a+b(f f)+c(f f)^{2} \\
\text { EIRFlowModFac }=a+b(f f)+c(f f)^{2} \\
\text { PLF }=a+b(P L R)+c(P L R)^{2} \\
R T F=P L R / P L F
\end{gathered}
$$

Where $\dot{Q}_{\text {total,rated }}$ and $C O P_{\text {rated }}$ are the total cooling capacity and COP at the rated condition. $\dot{Q}_{\text {total }}$ and Power are the total cooling capacity and power consumption considering variations in air temperature entering the condenser coil, indoor returning air wet bulb temperature, indoor air flow fraction and part-load ratio. EIR is called energy input ratio. It has to be noted, that the cooling capacity here is the total capacity without subtracting the indoor fan heat, and the EIR and $C O P_{\text {rated }}$ are only related to outdoor unit (compressor and condenser fan power).

TotCapTempModFac and EIRCapTempModFac are the correction fractions of total cooling capacity and EIR to the rated values, which are the functions of condenser entering air temperature and indoor wet bulb temperature. TotCapFlowModFac and EIRFlowModFac are the correction fractions, considering the changes in indoor air flow rate, where $f f$ is the ratio of actual indoor air flow rate to the nominal flow rate. RTF is named as running time fraction, PLF is the part load fraction as function of $P L R$. And $P L R$ is called part load ratio, which is the ratio of actual indoor sensible cooling load to the rated steady-state sensible cooling capacity. The 
part-load performance of a rooftop is unit is also its cyclic behavior, i.e., the time needed to reach steady-state after starting and energy loss during this period.

For simulating a unit with an evaporatively cooled condenser, EnergyPlus simply corrects the condenser entering air temperature in the form as Eq. A.10,

$$
T_{c, i}=T_{w, o}+(1-\text { EvapCondEffectiveness })\left(T_{d b, o}-T w_{b, o}\right)
$$

Where $T_{d b, o}$ and $T_{w b, o}$ are the ambient dry bulb and wet bulb temperatures, respectively. EvapCondEffectiveness is the wet bulb efficiency of the evaporative pad, which is treated to be a function of condenser frontal air velocity and pad thickness. Since the condenser air velocity and the evaporative pad thickness are usually fixed for an existing rooftop unit, the EvapCondEffectiveness can be inputted as a constant value for a building simulation case.

EnergyPlus can auto-sizes rooftop equipment to match building sensible loads under design days - the statistically hottest day in summary. Operating conditions in design days would vary regarding to locations. Working as a safety factor, the equipment sizing factor is set to scale the equipment rated capacity. If the sizing factor is larger than unity, it means the equipment is oversized in comparison to the required building sensible load. Consequently, the building comfort level is increased, but at the expense of the cyclic loss. However, the equipment sizing factor might vary according to building type, since an individual building type might have a specific comfort level regulation.

EnergyPlus 5.0 is capable of simulating single-speed, two-speed and multiple-speed rooftop equipment. For a two-speed equipment, EnergyPlus uses the rated capacity at high speed to match the building peak sensible load in design days, and the rated capacity at low speed would be assumed as $1 / 3$ of the rated value at the high speed. In addition, for two-speed equipment, we can input evaporative pre-cooling wet bulb efficiency specific to each speed level.

Certainly, for modeling condenser evaporative pre-cooling, we need to consider the expense in exchange of the energy saving, which are water evaporated and pump power consumed. In EnergyPlus, the evaporative condenser pump rated power consumption is modeled as the total cooling capacity times 0.004266 watts pump power per watt rated capacity, i.e., $15 \mathrm{~W} /$ ton. For two-speed rooftop equipment, at low speed, the pump power is set equal to $1 / 3$ times the total cooling capacity times 0.004266 watts pump power per watt capacity.

The water consumptions rate is calculated by the difference between the entering and exit air specific humidity.

$$
\dot{m}_{\text {water }}=\dot{m}_{\text {air }}\left(\omega_{\text {out }}-\omega_{\text {in }}\right)
$$

Where $\dot{m}_{\text {air }}$ and $\dot{m}_{\text {water }}$ are the air flow and water evaporation rate; a standard rated condenser air flow rate is between $0.00004027 \mathrm{~m}^{3} / \mathrm{s}$ and $0.00006041 \mathrm{~m}^{3} / \mathrm{s}$ per watt of rated total cooling capacity, i.e., 300-450 cfm/ton. $\omega_{\text {in }}$ and $\omega_{\text {out }}$ are the air entering and exit specific humidity. The water evaporation amount would be integrated along the running time fraction during operation. 


\section{A.1 PERFORMANCE CURVES OF DIFFERENT REFRIGERANTS}

In the DOE commercial benchmark building examples, most of the rooftop equipment were modeled using a single set of performance curves, which had been obtained from a 10-ton R-22 unit (Lennox T-Class). We stay with the equipment performance curves for R-22 equipment in our simulations; however, there are no R-410A equipment performance curves in the benchmark building database. So, we need to reduce R-410A curves by ourselves.

For air conditioning application, R-410A usually works at near-critical condition. With increasing ambient temperature, particularly above $35^{\circ} \mathrm{C}$, the equipment performance of R-410A can degrade much faster than that of R-22. Payne and Domanski (2002) compared an R-22 and a $\mathrm{R}-410 \mathrm{~A}$ air conditioner operating at high ambient temperature. The two air conditioner systems were tested using the same evaporator and condenser heat exchangers. The capacity and COP of the R-410A system was compared to those of the R-22 system in terms of normalized ratios. The capacities of R-22 and R-410A systems matched each other at $35^{\circ} \mathrm{C}$ and COPs matched each other at $27^{\circ} \mathrm{C}$. With changing the ambient temperature from $25^{\circ} \mathrm{C}$ to $55^{\circ} \mathrm{C}$, the capacity normalized ratio degraded from 1.05 to 0.90 , and the COP ratio was reduced from 1.05 to 0.80 . The results implied that the R-410A system was more sensitive to the increased outdoor temperature. Rice (2005) conducted a comprehensive system simulation studies comparing R-410A to R-22, which basically confirmed the same conclusion.

The condenser evaporative pre-cooling achieves energy saving by lowering the air temperature entering the condenser coil. Consequently, the energy saving effect is directly related to how the working refrigerant responds to entering air temperature. To have a direct comparison, we obtained product literature and reduced the data in the forms of EnergyPlus equipment performance curves [Eqs. (A.1) to (A.9)]. The comparisons between the R-22 curves and R-410A curves (10-ton two-speed, Lennox Strategeos) can be seen in Figs. A.1 and A.2.

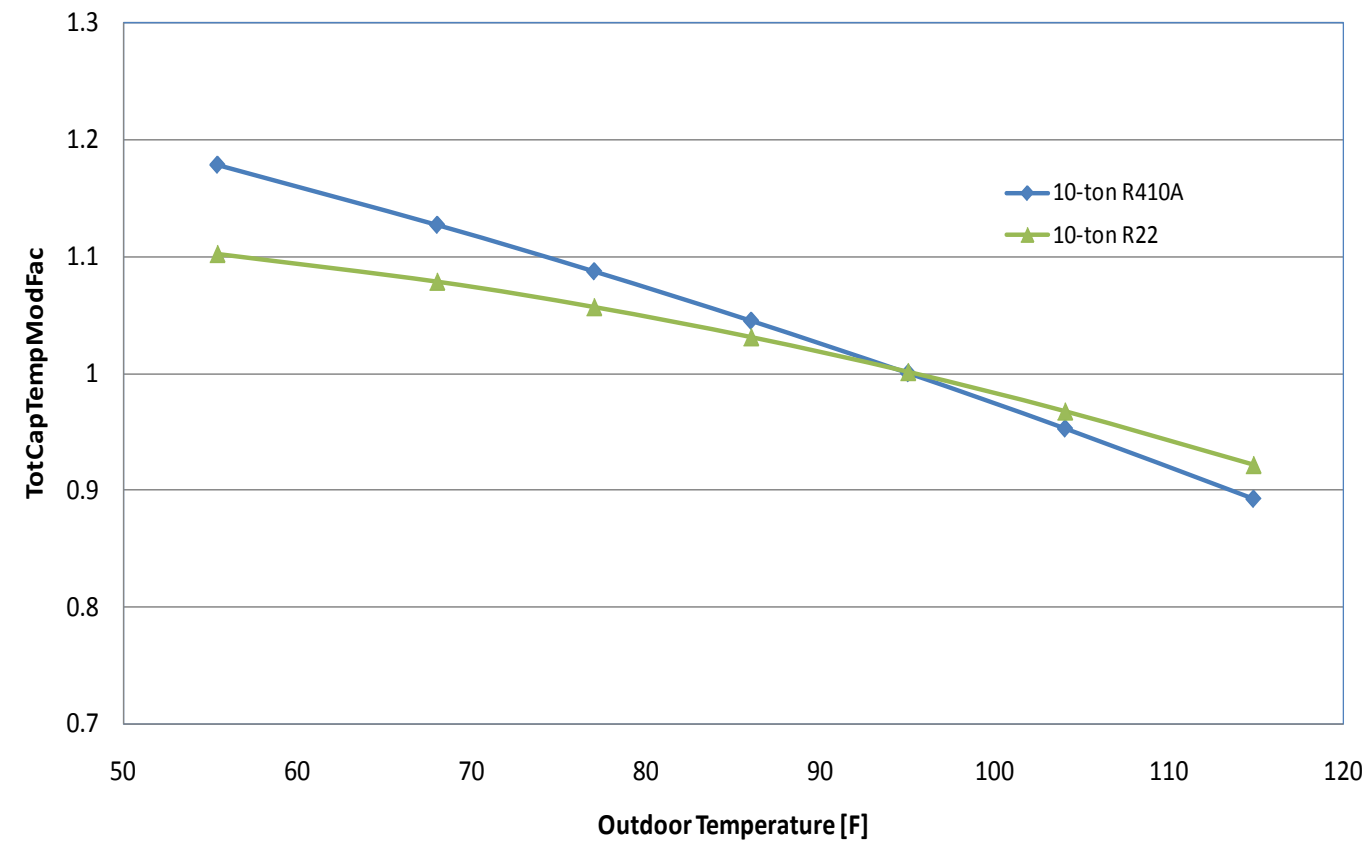

Fig. A.1. Total cooling capacity correction ratios of R-22 and R-410A varying with outdoor air dry bulb temperature and fixing indoor wet bulb at $67^{\circ} \mathrm{F}$. 


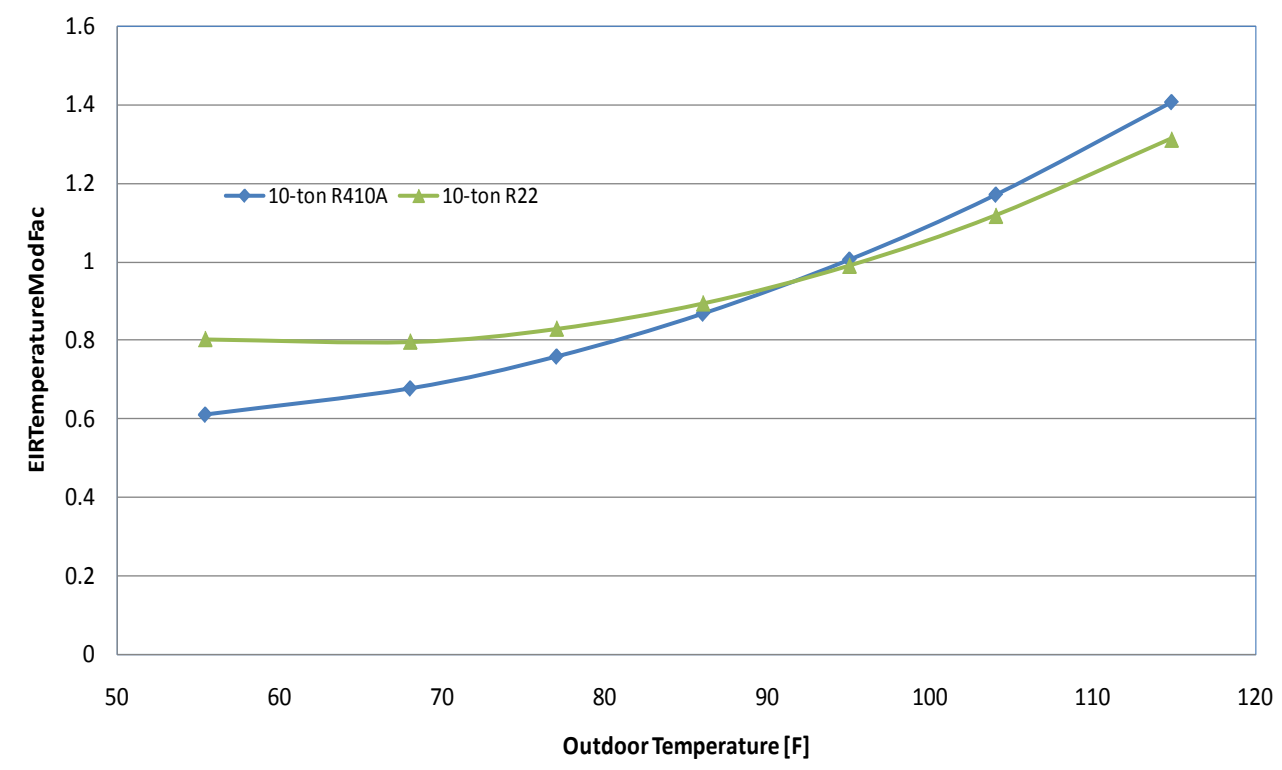

Fig. A.2. EIR correction ratios of $R-22$ and $R-410 A$ varying with outdoor air temperature and fixing indoor $\mathrm{WB}$ at $67^{\circ} \mathrm{F}$.

With fixing indoor wet bulb temperature at $67^{\circ} \mathrm{F}$, Fig. A.1 shows the capacity correction ratio and Fig. A.2 shows the EIR correction ratio, as a function of the air temperature entering the condenser coil.

We can see that both the total cooling capacity and EIR curves of R-410A change more drastically than R22. Changing the outdoor temperature from $115^{\circ} \mathrm{F}$ to $55^{\circ} \mathrm{F}$, the relative change in capacity for R-22 (compared to the total capacity at $95^{\circ} \mathrm{F}$ outdoor temperature) is $52 \%$, however, the change for R-410A is 79\%; the relative change in EIR for R-22 (compared to the EIR at $95^{\circ} \mathrm{F}$ outdoor temperature) is $18 \%$, however, the change for R-410A is $29 \%$. This means, given the same rating capacity and EIR at the design condition, the R-410A equipment would get more capacity and operate more efficiently, with the same drop in outdoor temperature.

Consequently, applying the same condenser evaporative precooling load, the R-410A equipment will get more relative power reduction than the R-22 equipment.

We want to establish how well a single set of R-410A equipment performance curves can represent equipment from different manufacturers and of different sizes. Comparisons were made against five Lennox equipment (Lennox Strategeos, R-410A), ranging from 10 tons to 24 tons, having compressor stages of 2 and 4, and one York 15 ton R-410A rooftop unit. In addition, the R-22 10-ton unit (Lennox T-Class) was included in the comparisons. The relative product information is given in Table A.1. The comparisons were given as relative deviation: (standard R-410A 10-ton curve predicted-individual equipment performance)/ (standard R410A 10-ton curve predicted). The individual equipment performance data were obtained from the product manual as functions of outdoor dry bulb temperature and indoor wet bulb temperature. Figure A.3 shows the comparisons of EIR corrections, and Fig. A.4 shows the comparisons for capacity corrections. It is apparent that the difference in refrigerants leads to the biggest difference of EIR and capacity corrections ratios as function of outdoor temperature. Especially for the EIR curves at low ambient temperatures, we can see $25 \%$ difference in the relative performances of R-410A and R-22; however, the differences due to other factors are within $5 \%$. 
Table A.1. Rooftop equipment product information

\begin{tabular}{|c|c|c|c|c|c|c|}
\hline Model No & Manufacturer & Refrigerant & Capacity & $\begin{array}{c}\text { Rated } \\
\text { EER }\end{array}$ & $\begin{array}{c}\text { Compressor } \\
\text { stages }\end{array}$ & $\begin{array}{c}\text { Condenser frontal air } \\
\text { velocity [fpm] }\end{array}$ \\
\hline SGA120H4B & Lennox & R-410A & 10-ton & 12.3 & 2-stage & 251 \\
\hline SGA120H4M & Lennox & R-410A & 10-ton & 12.1 & 2-stage & 251 \\
\hline SGA240H4B & Lennox & R-410A & 20-ton & 12.6 & 2-stage & 319 \\
\hline SGA240H4M & Lennox & R-410A & 20-ton & 12.6 & 4-stage & 319 \\
\hline SGB288H4B & Lennox & R-410A & 24-ton & 11.6 & 2-stage & 347 \\
\hline SGB288H4M & Lennox & R-410A & 24-ton & 11.6 & 4-stage & 347 \\
\hline J15ZJ & York & R-410A & 15-ton & 12.4 & 4-stage & 251 \\
\hline TGA120S2B & Lennox & R-22 & 10-ton & 10.1 & 2-stage & 273 \\
\hline
\end{tabular}

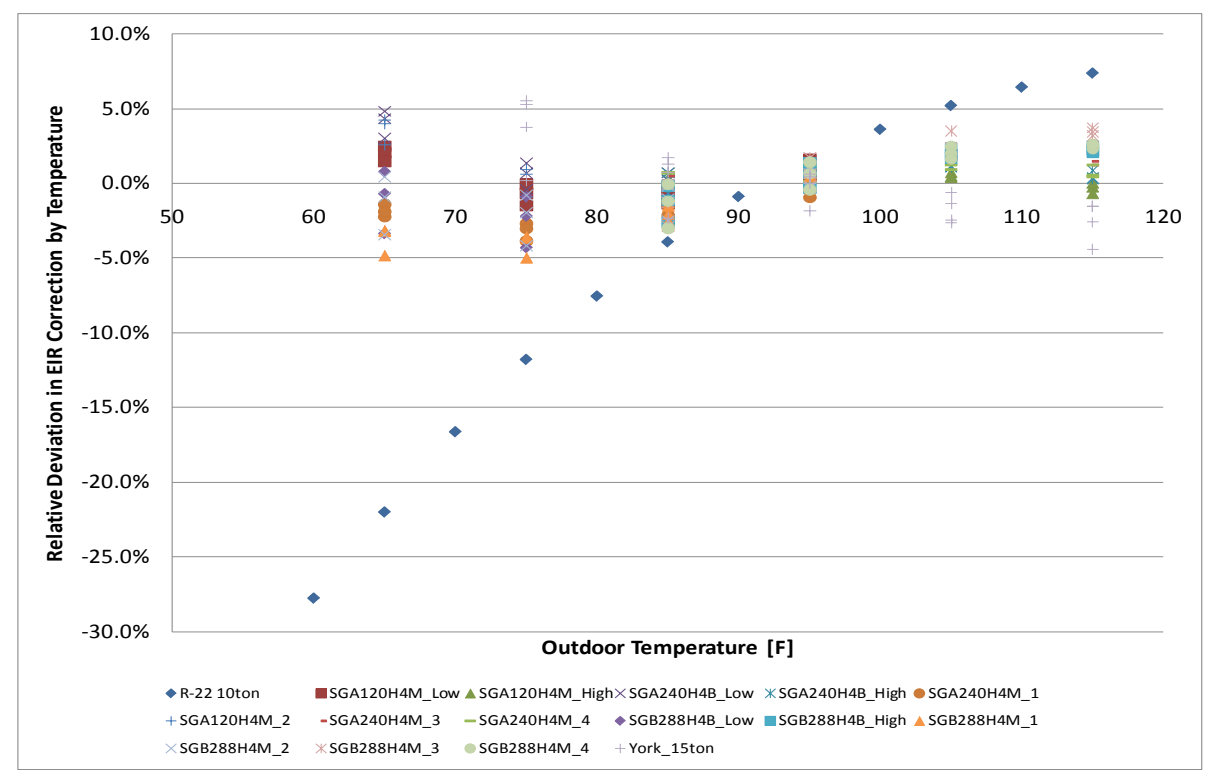

Fig. A.3. Comparisons of EIR correction ratios between baseline R-410A equipment curve and equipment of different sizes, manufacturers, and refrigerants. 


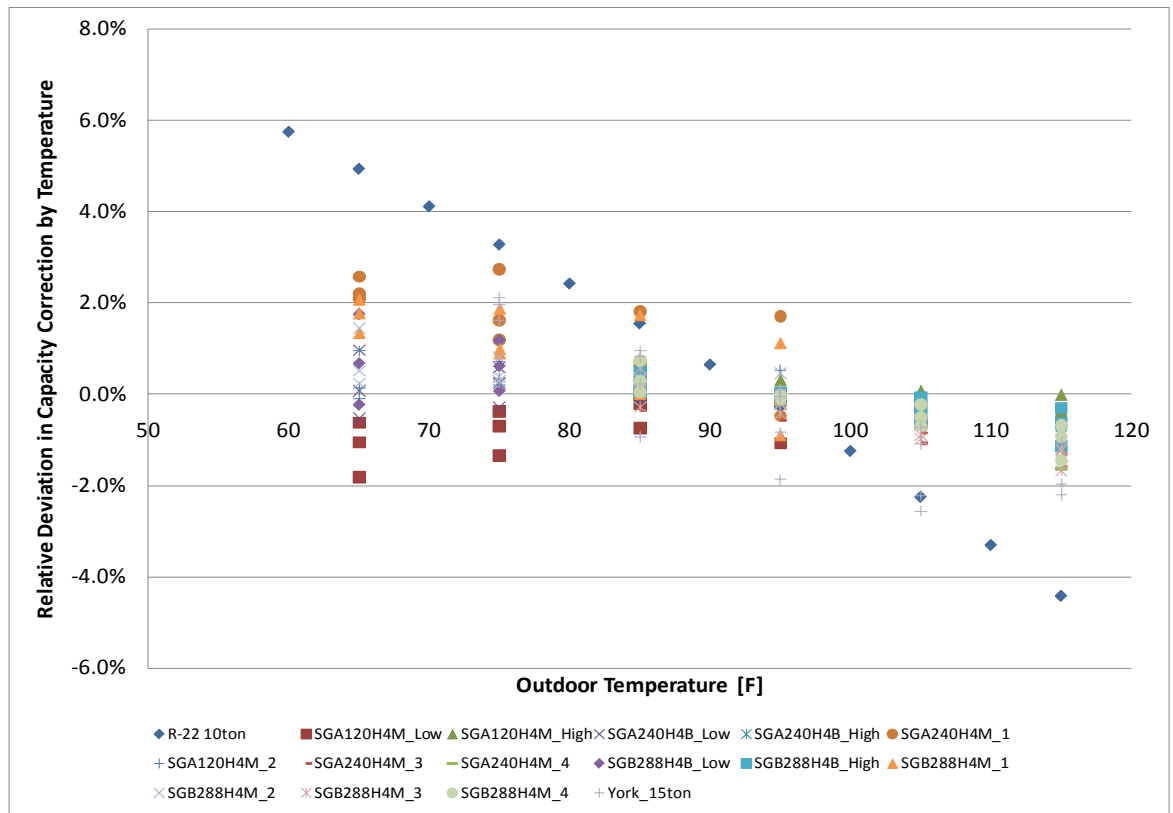

Fig. A.4. Comparisons of capacity correction ratios between baseline R-410A equipment curve and equipment from different sizes, manufacturers and refrigerants.

The comparison in Fig. A.3 and Fig. A.4 basically demonstrate that, for equipment using the same refrigerant (R-22 or R-410A), we can approximately choose a single set of performance curves to represent the equipment; however, for equipment using a different refrigerant, we have to use a separate set of curves specific to that refrigerant. 


\section{APPENDIX B. MULTIPLE VARIABLE ANALYSIS USING 2-LEVEL DESIGN-OF-EXPERIMENTS}

Our goal is to investigate the relative energy saving and peak power reduction due to the precooling effect, through a year as indicted in Eqs. (B.1) and (B.2).

$$
\begin{aligned}
& \text { EnergySaving }=\frac{\sum_{i=1}^{n} \text { Power }_{\text {noprecooling }, i} \Delta t_{i}-\sum_{j=1}^{m} \text { Power }_{\text {precooling }, i} \Delta t_{j}}{\sum_{i=1}^{n} \text { Power }_{\text {noprecooling }, i} \Delta t_{i}} \\
& =\frac{\sum_{i=1}^{n}\left(\frac{\dot{Q}_{\text {total, rated }}}{C O P_{\text {rated }}}\right) \text { func }\left(T_{d b,} T_{w b}\right) \Delta t_{i}-\sum_{j=1}^{m}\left(\frac{\dot{Q}_{\text {total, rated }}}{C O P_{\text {rated }}}\right) \text { func }\left(T_{c i,} T_{w b}\right) \Delta t_{j}}{\sum_{i=1}^{n}\left(\frac{\dot{Q}_{\text {total, rated }}}{C O P_{\text {rated }}}\right) \text { func }\left(T_{d b,} T_{w b}\right) \Delta t_{i}} \\
& \text { PeakReduction }=\frac{\max \left[\left(\frac{\dot{Q}_{\text {total, rated }}}{C O P_{\text {rated }}}\right) \operatorname{func}\left(T_{d b}, T_{w b}\right)_{i}\right]_{i=1}^{n}-\max \left[\left(\frac{\dot{Q}_{\text {total, rated }}}{C O P_{\text {rated }}}\right) f u n c\left(T_{c i,} T_{w b}\right)_{j}\right]_{j=1}^{m}}{\left.\max \left(\frac{\dot{Q}_{\text {total, rated }}}{C O P_{\text {rated }}}\right) \operatorname{func}\left(T_{d b}, T_{w b}\right)_{i}\right]_{i=1}^{n}}
\end{aligned}
$$

In Eqs. (B.2) or (B.2), the denominator gives the integrated or maximum power consumption without the precooling effect in a year, and the numerator gives the power difference between the baseline equipment without pre-cooling effect and the equipment with pre-cooling effect. The equipment performance without pre-cooling effect is a function of ambient temperature and indoor wet bulb temperature; on the other hand, the equipment performance with pre-cooling effect is a function of condenser entering air temperature after the evaporative pre-cooling process. It shall be noted, for a single equipment, since the $\left(\frac{\dot{Q}_{\text {total, rated }}}{C O P_{\text {rated }}}\right)$ is a constant value existing in both the numerator and the denominator, it can be removed, and consequently, has no impact on the relative annual energy saving and peak power reduction. The relative energy saving and power reduction shall mainly depend on the integrated or maximum changes in TotCapTempMOdFac, EIRCapTempModFac, TotCapFlowModFac, EIRFlowModFac due to the pre-cooling effect.

The pre-cooling effect depends on responses to indoor air flow variation, dynamic degradation behavior, pad wet bulb effectiveness, refrigerant types, etc. Moreover, the part load performances of single-speed and two-speed units can differ; rooftop equipment would be applied in numerous types of buildings and climate zones. The DOE commercial benchmark building database contains the building examples of three generations-present, post-1980 and pre-1980, which are related to different building energy regulations like efficiency, insulation types, etc. 
To identify the key process variables (KPIV) — what really matter, as shown in Fig. B.1, we adopted a 2-level Design-of-Experiments to investigate the significances of the influential factors. The influential factors are classified to three categories, i.e., environment, equipment and add-on. The equipment category is mainly about the variables of rooftop equipment; environment category is about the surrounding conditions where the equipment are operating; the add-on factor is wet bulb efficiency variation due to pad design and air velocity. In total, there are nine factors for the investigations. Here, we included the refrigerant factor to environment category instead of equipment, because the refrigerant application is mostly determined by regulation rather than customers' choice, which is more like a generation factor. For the Designof-Experiment analysis, we used Minitab 16, which is a six-sigma statistical analysis tool.

The principle of the 2-level Design-of-Experiments is to select high and low bounds of the influential variables and investigate the relative responses (annual energy saving and peak power reduction). The annual energy saving and peak power reduction were simulated using EnergyPlus and the benchmark commercial building examples. A complete 2-level Design-ofExperiments for 9 variables will run for $2^{9}=512$ cases. To simplify this analysis, we split the analyses into two sub-matrixes, one aims to investigate the equipment factors as listed in Table B.1 and the other is to investigate the environment factors as listed in Table B.2.

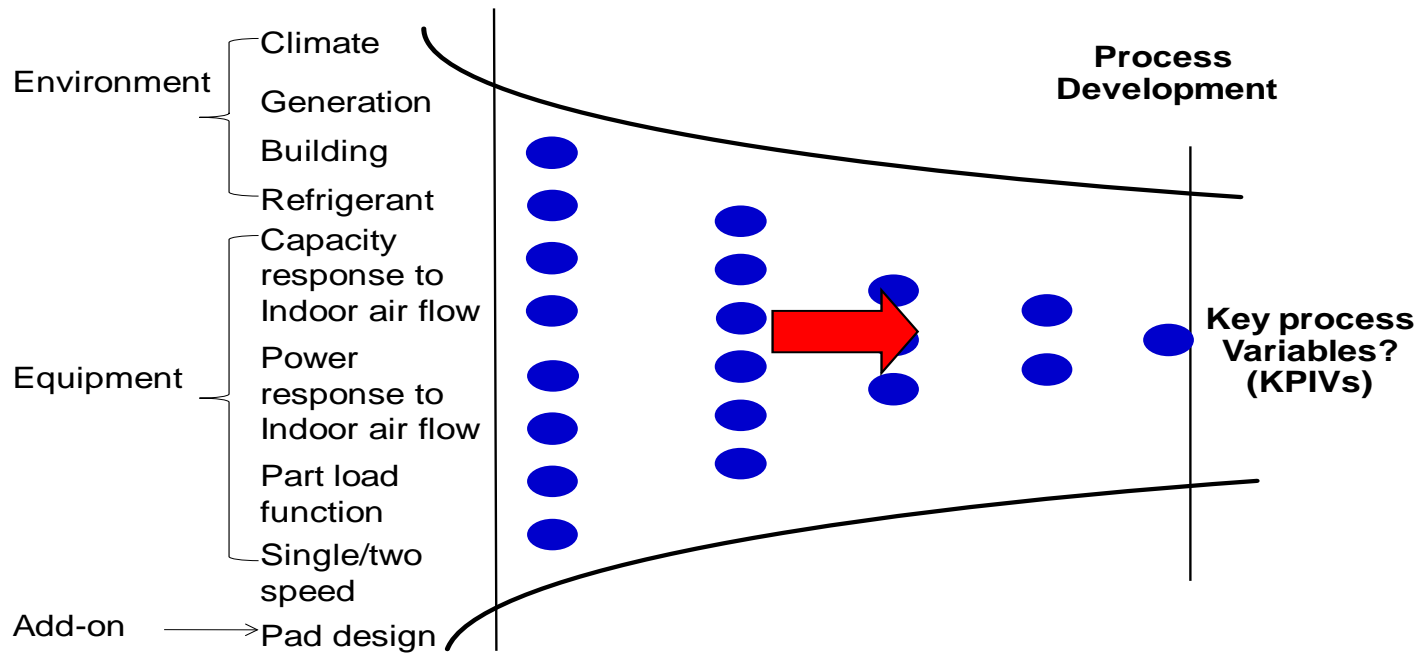

Fig. B.1. Influential variables for the pre-cooling effect.

Table B.1. Matrix of 2-level design-of-experiments for equipment factors

\begin{tabular}{|l|l|l|}
\hline \multicolumn{1}{|c|}{ Variable } & \multicolumn{1}{|c|}{ Low Level } & \multicolumn{1}{c|}{ High Level } \\
\hline $\begin{array}{l}\text { Speed level (abbreviation: } \\
\text { speed) }\end{array}$ & Single-speed & Two-speed \\
\hline $\begin{array}{l}\text { Part load function } \\
\text { (degradation) }\end{array}$ & $0.9+0.1 *$ PLR & $0.771+0.229 *$ PLR \\
\hline $\begin{array}{l}\text { Capacity response to } \\
\text { indoor air flow variation } \\
\text { (FFCap) }\end{array}$ & $0.77136+0.34053 * \mathrm{ff}-0.11088 * \mathrm{ff}^{2}$ & $0.25+0.75 * \mathrm{ff}$ \\
\hline $\begin{array}{l}\text { EIR response to indoor air } \\
\text { flow variation (FFEIR) }\end{array}$ & $1.20550-0.32953 * \mathrm{ff}+0.12308 * \mathrm{ff}^{2}$ & $1.5-0.5 * \mathrm{ff}$ \\
\hline $\begin{array}{l}\text { Pad wet bulb efficiency } \\
\text { (effect) }\end{array}$ & 0.5 & 0.9 \\
\hline
\end{tabular}


Table B.2. Matrix of 2-level design of experiments for environment factors

\begin{tabular}{|l|l|l|}
\hline \multicolumn{1}{|c|}{ Variable } & \multicolumn{1}{|c|}{ Low level } & High level \\
\hline Generation & Pre-1980 & Present \\
\hline Refrigerant & R-22 & R-410A \\
\hline Building & Secondary school & Supermarket \\
\hline City & Los Angeles, CA & Phoenix, AZ \\
\hline Pad Wet bulb efficiency & 0.5 & 0.9 \\
\hline
\end{tabular}

While investigating the equipment related factors, we adopted the benchmark medium office building in Pheonix, AZ, at present generation, having R-410A refrigerant and variable indoor air flow system (VAV). In Table B.1. The curves for high level part load function, low level capacity response to indoor air flow, and low level EIR response to indoor air flow are typical equipment performance curves given in the benchmark building example; while the curves at other levels were intentionally pushed to extremes.

While investigating the environment related factors, the other equipment factors are fixed as single speed, high level part load function, low level of capacity and EIR responses to indoor air flow. The add-on factor of pad wet bulb efficiency was put in both the environment and equipment matrixes, as intended to provide cross-comparison between the two matrixes.

Among the equipment factors, the standardized effects are compared in Figs. B.2 and B.3, for annual energy and peak power reduction, respectively. Among the environment factors, the standardized effects are compared in Figs. B.4 and B.5. The comparisons standardized effects can show relative significances of multiple factors impacting one response. In comparison to the other equipment factors, the media pad wet bulb efficiency shows much more significant effect, for both the annual energy saving and peak power reduction. Among the environment factors, city, refrigerant, pad design and building type have significant effects on the annual energy

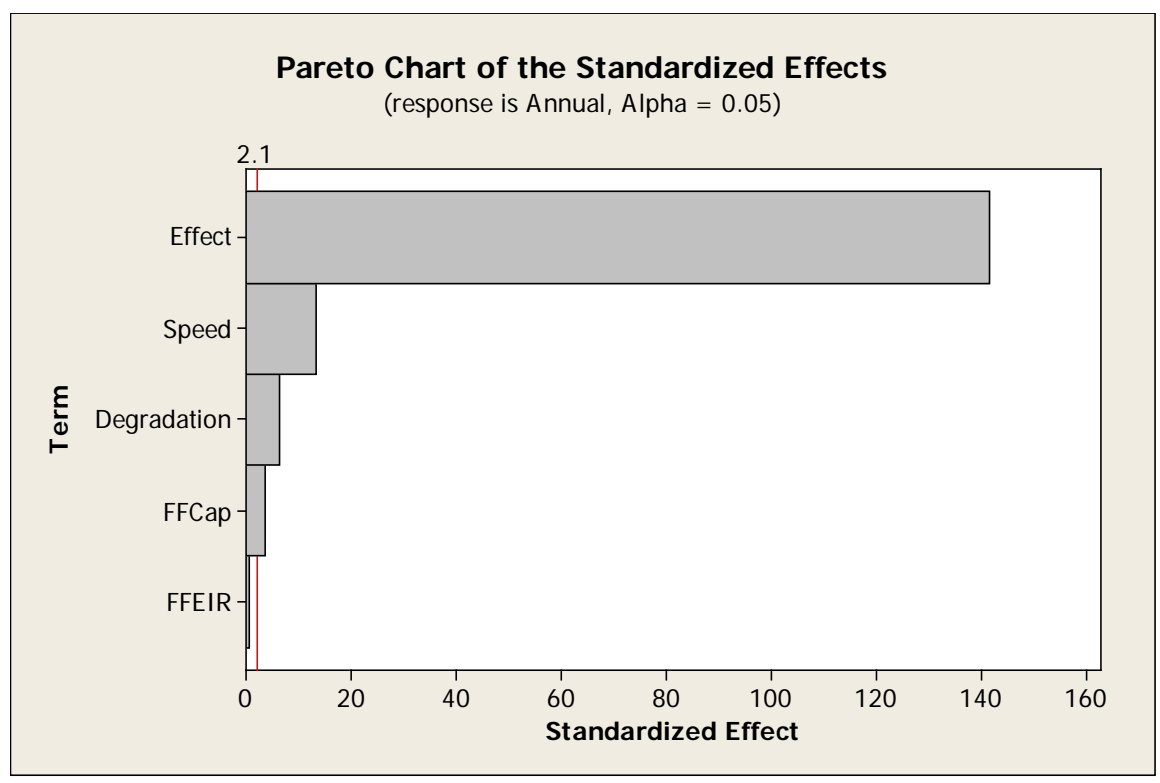

Fig. B.2. Standardized effects of equipment factors on annual energy saving (see Table B.1 for the terms). 


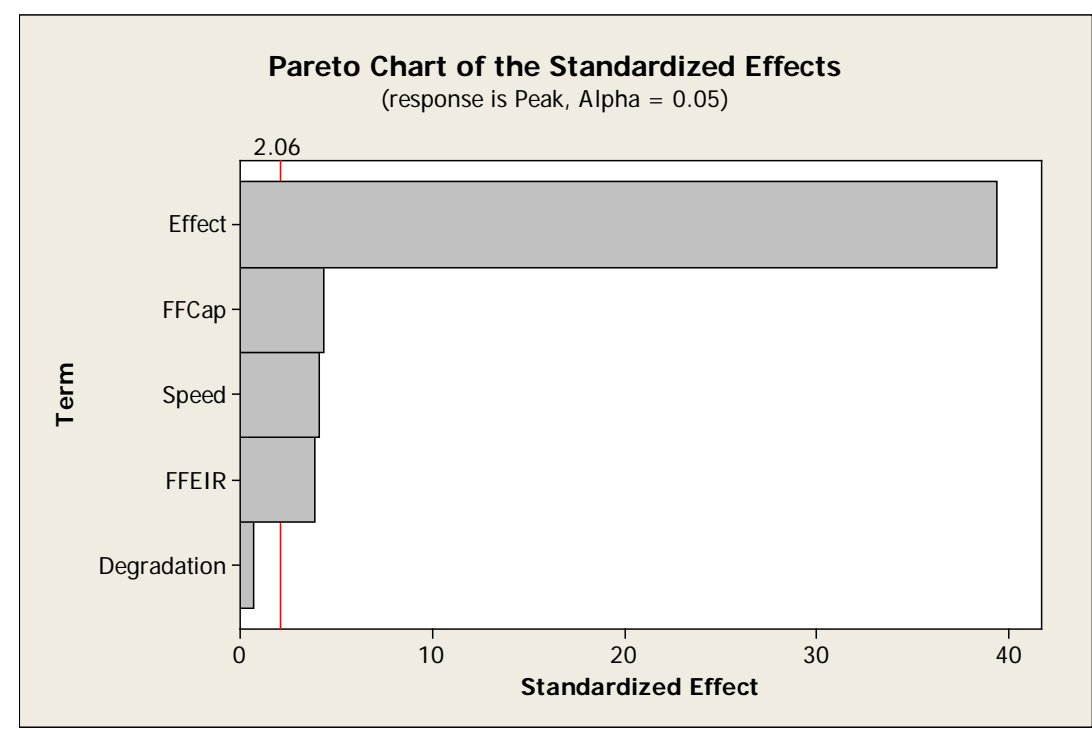

Fig. B.3. Standardized effects of equipment factors on peak power reduction (see Table B.1 for the terms).

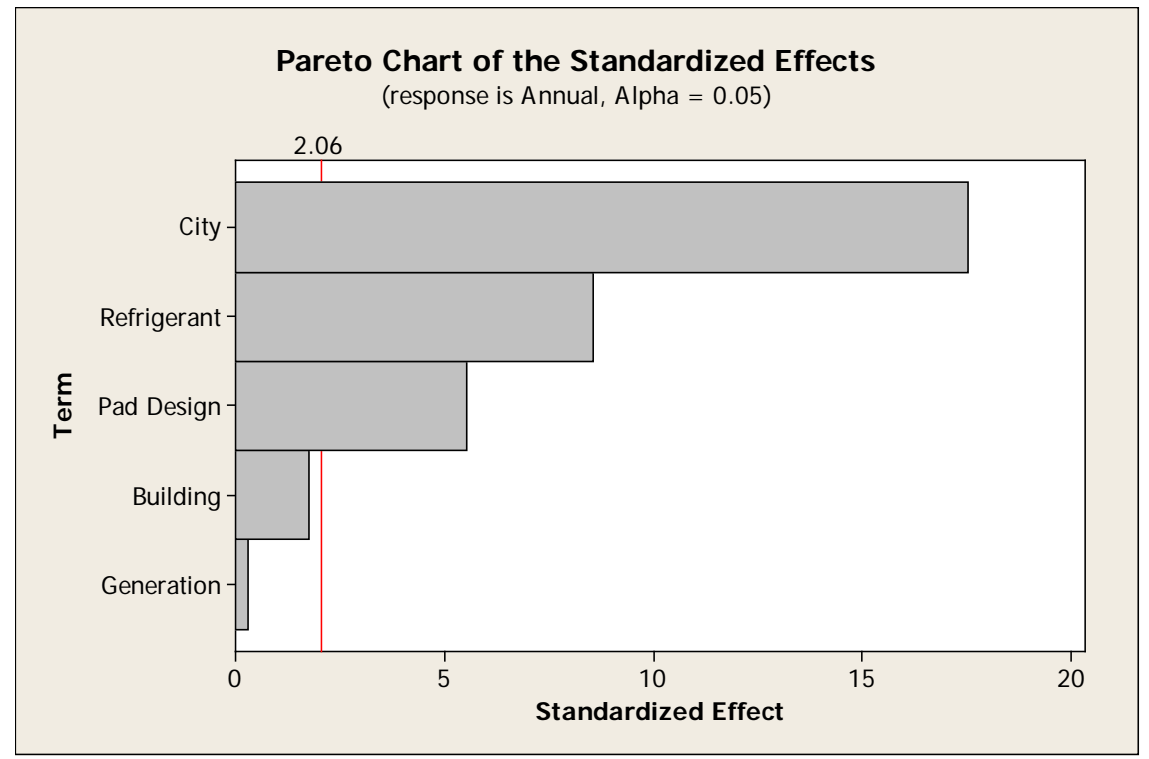

Fig. B.4. Standardized effects of environment factors on annual energy saving (see Table B.2 for the terms). 


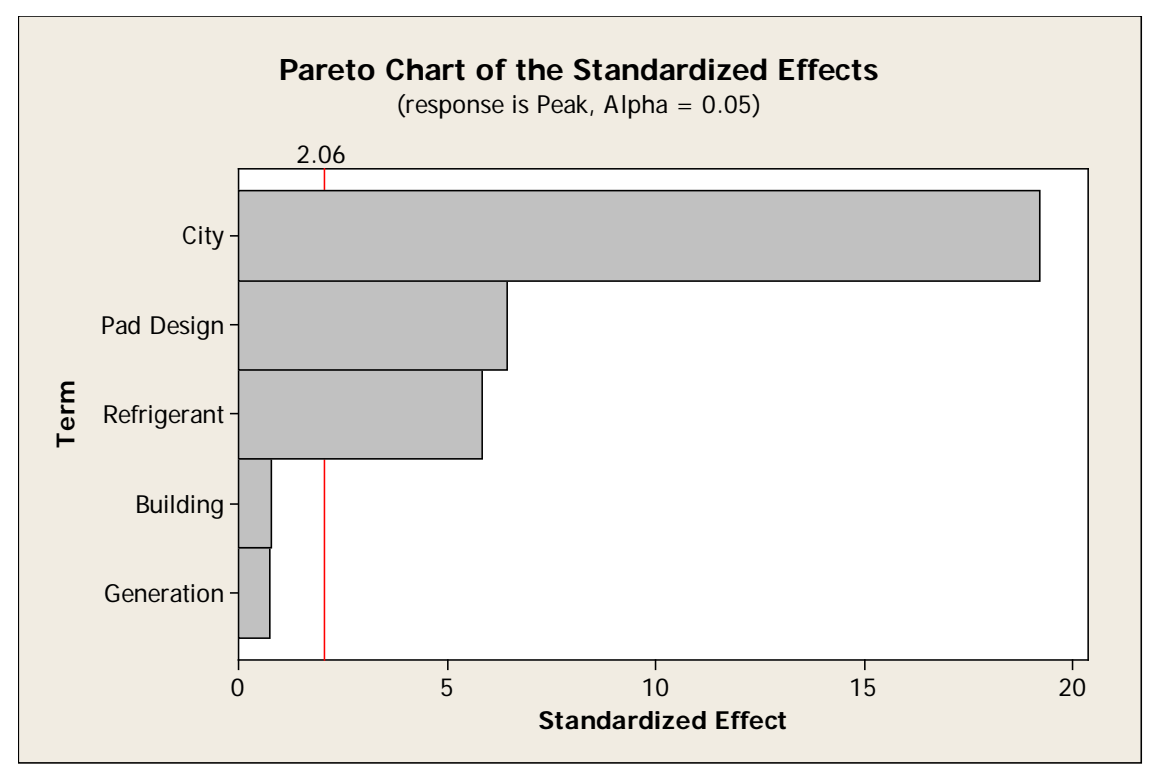

Fig. B.5. Standardized effects of environment factors on peak power reduction (see Table B.2 for the terms).

saving, while the influence from building generations can be ignored. For the peak power reduction, city, pad design and refrigerant have significant effects, while the factors of building types and building generations can be ignored.

All in all, in order to provide a comprehensive assessment for the pre-cooling technique used in the US commercial building market, but based on a limited set of simulation cases, we need to focus on the four primary factors of city, refrigerant, pad wet bulb efficiency and building type. 



\section{APPENDIX C. TABLES OF ANNUAL ENERGY SAVINGS AND PEAK LOAD REDUCTIONS}

For the simulations listed in this section, we studied three levels of wet bulb efficiency, $\mathrm{Ewb}=0.5$ (Ewb05), Ewb = 0.7 (Ewb07), and Ewb = 0.9 (Ewb09); three commercial building types, i.e., medium office, secondary school and supermarket. We also considered three building generations, i.e., present, post-1980 and pre-1980; for the present building generation, we presented data in Tables C.1 through C.11 for two refrigerants, i.e., R-410A and R-22. 


\section{C.1 PRESENT BUILDING GENERATION}

Medium Office:

Table C.1. Energy assessments, medium office, R-410A, present

\begin{tabular}{|c|c|c|c|c|c|c|}
\hline \multirow{2}{*}{$\begin{array}{l}\text { R410A } \\
\text { city }\end{array}$} & \multicolumn{3}{|c|}{ Annual energy saving } & \multicolumn{3}{|c|}{ Peak power reduction } \\
\hline & Ewb05 & Ewb07 & Ewb09 & Ewb05 & Ewb07 & Ewb09 \\
\hline $\begin{array}{l}\text { Albuquerque, } \\
\text { New Mexico }\end{array}$ & $11.0 \%$ & $14.5 \%$ & $17.1 \%$ & $21.1 \%$ & $26.7 \%$ & $31.4 \%$ \\
\hline $\begin{array}{l}\text { Los Angeles, } \\
\text { California }\end{array}$ & $2.3 \%$ & $3.5 \%$ & $4.6 \%$ & $3.8 \%$ & $5.7 \%$ & $7.5 \%$ \\
\hline $\begin{array}{l}\text { Atlanta, } \\
\text { Georgia }\end{array}$ & $4.0 \%$ & $5.9 \%$ & $7.6 \%$ & $14.0 \%$ & $19.3 \%$ & $24.0 \%$ \\
\hline $\begin{array}{l}\text { Baltimore, } \\
\text { Maryland }\end{array}$ & $4.1 \%$ & $6.0 \%$ & $7.6 \%$ & $8.2 \%$ & $11.1 \%$ & $13.8 \%$ \\
\hline $\begin{array}{l}\text { Boulder, } \\
\text { Colorado }\end{array}$ & $10.1 \%$ & $13.3 \%$ & $15.6 \%$ & $24.3 \%$ & $31.4 \%$ & $36.1 \%$ \\
\hline $\begin{array}{l}\text { Chicago, } \\
\text { Illinois }\end{array}$ & $4.8 \%$ & $7.0 \%$ & $8.9 \%$ & $8.9 \%$ & $11.3 \%$ & $13.5 \%$ \\
\hline $\begin{array}{l}\text { Duluth, } \\
\text { Minnesota }\end{array}$ & $3.5 \%$ & $5.2 \%$ & $6.6 \%$ & $9.5 \%$ & $13.2 \%$ & $16.6 \%$ \\
\hline $\begin{array}{l}\text { Fairbanks, } \\
\text { Alaska }\end{array}$ & $4.3 \%$ & $6.0 \%$ & $7.3 \%$ & $8.6 \%$ & $11.9 \%$ & $14.6 \%$ \\
\hline $\begin{array}{l}\text { San } \\
\text { Francisco, } \\
\text { California }\end{array}$ & $2.6 \%$ & $3.9 \%$ & $5.0 \%$ & $18.9 \%$ & $24.9 \%$ & $29.7 \%$ \\
\hline $\begin{array}{l}\text { Helena, } \\
\text { Montana }\end{array}$ & $8.7 \%$ & $11.6 \%$ & $13.8 \%$ & $20.0 \%$ & $26.3 \%$ & $31.4 \%$ \\
\hline $\begin{array}{l}\text { Houston, } \\
\text { Texas }\end{array}$ & $4.5 \%$ & $6.6 \%$ & $8.6 \%$ & $10.4 \%$ & $13.8 \%$ & $16.5 \%$ \\
\hline $\begin{array}{l}\text { Miami, } \\
\text { Florida }\end{array}$ & $4.0 \%$ & $6.0 \%$ & $7.9 \%$ & $8.0 \%$ & $11.4 \%$ & $14.6 \%$ \\
\hline $\begin{array}{l}\text { Minneapolis, } \\
\text { Minnesota }\end{array}$ & $4.3 \%$ & $6.3 \%$ & $8.0 \%$ & $8.2 \%$ & $11.3 \%$ & $14.2 \%$ \\
\hline $\begin{array}{l}\text { Phoenix, } \\
\text { Arizona }\end{array}$ & $16.4 \%$ & $21.6 \%$ & $25.9 \%$ & $25.8 \%$ & $33.9 \%$ & $40.7 \%$ \\
\hline $\begin{array}{l}\text { Seattle, } \\
\text { Washington }\end{array}$ & $3.6 \%$ & $5.2 \%$ & $6.6 \%$ & $12.0 \%$ & $15.7 \%$ & $18.9 \%$ \\
\hline $\begin{array}{l}\text { Las Vegas, } \\
\text { Nevada }\end{array}$ & $18.0 \%$ & $23.4 \%$ & $27.5 \%$ & $28.1 \%$ & $36.4 \%$ & $40.7 \%$ \\
\hline Average & $6.6 \%$ & $9.1 \%$ & $11.2 \%$ & $14.4 \%$ & $19.0 \%$ & $22.8 \%$ \\
\hline Max & $18.0 \%$ & $23.4 \%$ & $27.5 \%$ & $28.1 \%$ & $36.4 \%$ & $40.7 \%$ \\
\hline Min & $2.3 \%$ & $3.5 \%$ & $4.6 \%$ & $3.8 \%$ & $5.7 \%$ & $7.5 \%$ \\
\hline
\end{tabular}


Table C.2. Energy assessments, medium office, R-22, present

\begin{tabular}{|l|c|c|c|c|c|c|}
\hline \multirow{2}{*}{$\begin{array}{c}\text { R22 } \\
\text { city }\end{array}$} & \multicolumn{2}{|c|}{ Annual energy saving } & \multicolumn{3}{c|}{ Peak power reduction } \\
\cline { 2 - 7 } & Ewb05 & Ewb07 & Ewb09 & Ewb05 & Ewb07 & Ewb09 \\
\hline $\begin{array}{l}\text { Albuquerque, } \\
\text { New Mexico }\end{array}$ & $4.10 \%$ & $4.93 \%$ & $5.08 \%$ & $14.01 \%$ & $17.09 \%$ & $19.08 \%$ \\
\hline $\begin{array}{l}\text { Los Angeles, } \\
\text { California }\end{array}$ & $-0.66 \%$ & $-0.56 \%$ & $-0.54 \%$ & $0.74 \%$ & $1.42 \%$ & $1.97 \%$ \\
\hline $\begin{array}{l}\text { Atlanta, } \\
\text { Georgia }\end{array}$ & $0.90 \%$ & $1.55 \%$ & $2.04 \%$ & $9.94 \%$ & $13.27 \%$ & $15.95 \%$ \\
\hline $\begin{array}{l}\text { Baltimore, } \\
\text { Maryland }\end{array}$ & $1.01 \%$ & $1.69 \%$ & $2.19 \%$ & $3.92 \%$ & $5.73 \%$ & $7.38 \%$ \\
\hline $\begin{array}{l}\text { Boulder, } \\
\text { Colorado }\end{array}$ & $3.28 \%$ & $3.85 \%$ & $3.81 \%$ & $16.12 \%$ & $19.45 \%$ & $20.71 \%$ \\
\hline $\begin{array}{l}\text { Chicago, } \\
\text { Illinois }\end{array}$ & $1.20 \%$ & $1.87 \%$ & $2.34 \%$ & $2.60 \%$ & $3.98 \%$ & $5.23 \%$ \\
\hline $\begin{array}{l}\text { Duluth, } \\
\text { Minnesota }\end{array}$ & $0.07 \%$ & $0.39 \%$ & $0.57 \%$ & $5.12 \%$ & $7.03 \%$ & $8.53 \%$ \\
\hline $\begin{array}{l}\text { Fairbanks, } \\
\text { Alaska }\end{array}$ & $-0.38 \%$ & $-0.40 \%$ & $-0.60 \%$ & $2.96 \%$ & $3.86 \%$ & $4.26 \%$ \\
\hline $\begin{array}{l}\text { San } \\
\text { Francisco, } \\
\text { California }\end{array}$ & $-0.82 \%$ & $-0.83 \%$ & $-0.96 \%$ & $12.06 \%$ & $15.09 \%$ & $16.83 \%$ \\
\hline $\begin{array}{l}\text { Helena, } \\
\text { Montana }\end{array}$ & $2.34 \%$ & $2.81 \%$ & $2.79 \%$ & $13.50 \%$ & $16.78 \%$ & $17.90 \%$ \\
\hline $\begin{array}{l}\text { Houston, } \\
\text { Texas }\end{array}$ & $1.64 \%$ & $2.57 \%$ & $3.35 \%$ & $6.18 \%$ & $7.98 \%$ & $9.59 \%$ \\
\hline $\begin{array}{l}\text { Miami, } \\
\text { Florida }\end{array}$ & $1.27 \%$ & $2.12 \%$ & $2.83 \%$ & $4.87 \%$ & $6.94 \%$ & $8.76 \%$ \\
\hline $\begin{array}{l}\text { Minneapolis, } \\
\text { Minnesota }\end{array}$ & $0.78 \%$ & $1.35 \%$ & $1.73 \%$ & $4.05 \%$ & $5.83 \%$ & $7.39 \%$ \\
\hline $\begin{array}{l}\text { Phoenix, } \\
\text { Arizona }\end{array}$ & $9.82 \%$ & $12.34 \%$ & $13.80 \%$ & $21.85 \%$ & $27.78 \%$ & $32.04 \%$ \\
\hline $\begin{array}{l}\text { Seattle, } \\
\text { Washington }\end{array}$ & $-0.28 \%$ & $-0.15 \%$ & $-0.19 \%$ & $5.22 \%$ & $6.79 \%$ & $7.85 \%$ \\
\hline $\begin{array}{l}\text { Las Vegas, } \\
\text { Nevada }\end{array}$ & $10.42 \%$ & $12.75 \%$ & $13.84 \%$ & $23.21 \%$ & $28.29 \%$ & $30.62 \%$ \\
\hline Average & $2.2 \%$ & $2.9 \%$ & $3.3 \%$ & $9.1 \%$ & $11.7 \%$ & $13.4 \%$ \\
\hline Max & $10.4 \%$ & $12.8 \%$ & $13.8 \%$ & $23.2 \%$ & $28.3 \%$ & $32.0 \%$ \\
\hline Min & $-0.8 \%$ & $-0.8 \%$ & $-1.0 \%$ & $0.7 \%$ & $1.4 \%$ & $2.0 \%$ \\
\hline
\end{tabular}




\section{Secondary School:}

Table C.3. Energy assessments, secondary school, R-410A, present

\begin{tabular}{|c|c|c|c|c|c|c|}
\hline \multirow{2}{*}{$\begin{array}{l}\text { R410A } \\
\text { city }\end{array}$} & \multicolumn{3}{|c|}{ Annual energy saving } & \multicolumn{3}{|c|}{ Peak power reduction } \\
\hline & Ewb05 & Ewb07 & Ewb09 & Ewb05 & Ewb07 & Ewb09 \\
\hline $\begin{array}{l}\text { Albuquerque, } \\
\text { New Mexico }\end{array}$ & $12.84 \%$ & $16.91 \%$ & $19.90 \%$ & $21.59 \%$ & $26.95 \%$ & $31.57 \%$ \\
\hline $\begin{array}{l}\text { Los Angeles, } \\
\text { California }\end{array}$ & $4.01 \%$ & $5.85 \%$ & $7.43 \%$ & $8.62 \%$ & $11.00 \%$ & $13.14 \%$ \\
\hline $\begin{array}{l}\text { Atlanta, } \\
\text { Georgia }\end{array}$ & $5.59 \%$ & $8.04 \%$ & $10.24 \%$ & $10.89 \%$ & $13.98 \%$ & $16.73 \%$ \\
\hline $\begin{array}{l}\text { Baltimore, } \\
\text { Maryland }\end{array}$ & $5.73 \%$ & $8.21 \%$ & $10.45 \%$ & $8.21 \%$ & $11.13 \%$ & $13.10 \%$ \\
\hline $\begin{array}{l}\text { Boulder, } \\
\text { Colorado }\end{array}$ & $12.83 \%$ & $16.84 \%$ & $19.74 \%$ & $21.32 \%$ & $27.97 \%$ & $33.16 \%$ \\
\hline $\begin{array}{l}\text { Chicago, } \\
\text { Illinois }\end{array}$ & $6.01 \%$ & $8.57 \%$ & $10.85 \%$ & $7.32 \%$ & $10.09 \%$ & $12.47 \%$ \\
\hline $\begin{array}{l}\text { Duluth, } \\
\text { Minnesota }\end{array}$ & $5.68 \%$ & $8.10 \%$ & $10.22 \%$ & $5.56 \%$ & $8.03 \%$ & $10.31 \%$ \\
\hline $\begin{array}{l}\text { Fairbanks, } \\
\text { Alaska }\end{array}$ & $7.57 \%$ & $10.26 \%$ & $12.32 \%$ & $13.64 \%$ & $18.08 \%$ & $21.43 \%$ \\
\hline $\begin{array}{l}\text { San } \\
\text { Francisco, } \\
\text { California }\end{array}$ & $6.64 \%$ & $9.22 \%$ & $11.37 \%$ & $14.59 \%$ & $19.83 \%$ & $23.51 \%$ \\
\hline $\begin{array}{l}\text { Helena, } \\
\text { Montana }\end{array}$ & $11.93 \%$ & $15.86 \%$ & $18.87 \%$ & $17.31 \%$ & $22.66 \%$ & $27.09 \%$ \\
\hline $\begin{array}{l}\text { Houston, } \\
\text { Texas }\end{array}$ & $4.82 \%$ & $7.06 \%$ & $9.14 \%$ & $8.13 \%$ & $10.09 \%$ & $11.98 \%$ \\
\hline $\begin{array}{l}\text { Miami, } \\
\text { Florida }\end{array}$ & $3.76 \%$ & $5.66 \%$ & $7.45 \%$ & $6.34 \%$ & $8.48 \%$ & $10.16 \%$ \\
\hline $\begin{array}{l}\text { Minneapolis, } \\
\text { Minnesota }\end{array}$ & $5.47 \%$ & $7.87 \%$ & $10.03 \%$ & $7.03 \%$ & $9.49 \%$ & $11.81 \%$ \\
\hline $\begin{array}{l}\text { Phoenix, } \\
\text { Arizona }\end{array}$ & $16.47 \%$ & $21.92 \%$ & $26.30 \%$ & $21.21 \%$ & $28.18 \%$ & $34.05 \%$ \\
\hline $\begin{array}{l}\text { Seattle, } \\
\text { Washington }\end{array}$ & $6.36 \%$ & $8.89 \%$ & $11.03 \%$ & $9.47 \%$ & $12.98 \%$ & $15.96 \%$ \\
\hline $\begin{array}{l}\text { Las Vegas, } \\
\text { Nevada }\end{array}$ & $18.37 \%$ & $24.13 \%$ & $28.54 \%$ & $23.05 \%$ & $30.66 \%$ & $36.64 \%$ \\
\hline Average & $8.4 \%$ & $11.5 \%$ & $14.0 \%$ & $12.8 \%$ & $16.9 \%$ & $20.2 \%$ \\
\hline Max & $18.4 \%$ & $24.1 \%$ & $28.5 \%$ & $23.0 \%$ & $30.7 \%$ & $36.6 \%$ \\
\hline Min & $3.8 \%$ & $5.7 \%$ & $7.4 \%$ & $5.6 \%$ & $8.0 \%$ & $10.2 \%$ \\
\hline
\end{tabular}


Table C.4. Energy assessments, secondary school, R-22, present

\begin{tabular}{|l|c|c|c|c|c|c|}
\hline \multirow{2}{*}{$\begin{array}{c}\text { R22 } \\
\text { city }\end{array}$} & \multicolumn{3}{|c|}{ Annual energy saving } & \multicolumn{2}{c|}{ Peak power reduction } \\
\cline { 2 - 7 } & Ewb05 & Ewb07 & Ewb09 & Ewb05 & Ewb07 & Ewb09 \\
\hline $\begin{array}{l}\text { Albuquerque, } \\
\text { New Mexico }\end{array}$ & $5.53 \%$ & $6.52 \%$ & $6.61 \%$ & $14.23 \%$ & $16.41 \%$ & $17.34 \%$ \\
\hline $\begin{array}{l}\text { Los Angeles, } \\
\text { California }\end{array}$ & $0.28 \%$ & $0.58 \%$ & $0.68 \%$ & $1.53 \%$ & $2.25 \%$ & $2.69 \%$ \\
\hline Atlanta, Georgia & $1.77 \%$ & $2.61 \%$ & $3.20 \%$ & $6.88 \%$ & $8.65 \%$ & $9.98 \%$ \\
\hline $\begin{array}{l}\text { Baltimore, } \\
\text { Maryland }\end{array}$ & $2.05 \%$ & $2.96 \%$ & $3.61 \%$ & $5.19 \%$ & $7.03 \%$ & $8.17 \%$ \\
\hline $\begin{array}{l}\text { Boulder, } \\
\text { Colorado }\end{array}$ & $5.28 \%$ & $6.16 \%$ & $6.15 \%$ & $14.68 \%$ & $17.52 \%$ & $17.76 \%$ \\
\hline Chicago, Illinois & $1.97 \%$ & $2.83 \%$ & $3.40 \%$ & $4.27 \%$ & $5.77 \%$ & $7.00 \%$ \\
\hline $\begin{array}{l}\text { Duluth, } \\
\text { Minnesota }\end{array}$ & $1.36 \%$ & $1.97 \%$ & $2.30 \%$ & $1.78 \%$ & $2.68 \%$ & $3.34 \%$ \\
\hline $\begin{array}{l}\text { Fairbanks, } \\
\text { Alaska }\end{array}$ & $1.45 \%$ & $1.69 \%$ & $1.51 \%$ & $5.44 \%$ & $6.35 \%$ & $6.28 \%$ \\
\hline $\begin{array}{l}\text { San Francisco, } \\
\text { California }\end{array}$ & $1.49 \%$ & $1.93 \%$ & $1.95 \%$ & $8.52 \%$ & $10.49 \%$ & $11.52 \%$ \\
\hline $\begin{array}{l}\text { Helena, } \\
\text { Montana }\end{array}$ & $4.88 \%$ & $5.86 \%$ & $6.01 \%$ & $11.00 \%$ & $13.67 \%$ & $14.60 \%$ \\
\hline Houston, Texas & $1.69 \%$ & $2.60 \%$ & $3.32 \%$ & $4.91 \%$ & $6.08 \%$ & $7.14 \%$ \\
\hline Miami, Florida & $0.98 \%$ & $1.70 \%$ & $2.29 \%$ & $3.35 \%$ & $4.30 \%$ & $5.15 \%$ \\
\hline $\begin{array}{l}\text { Minneapolis, } \\
\text { Minnesota }\end{array}$ & $1.55 \%$ & $2.31 \%$ & $2.81 \%$ & $3.05 \%$ & $4.17 \%$ & $5.14 \%$ \\
\hline $\begin{array}{l}\text { Phoenix, } \\
\text { Arizona }\end{array}$ & $10.11 \%$ & $12.61 \%$ & $13.88 \%$ & $18.57 \%$ & $23.25 \%$ & $26.33 \%$ \\
\hline $\begin{array}{l}\text { Seattle, } \\
\text { Washington }\end{array}$ & $1.30 \%$ & $1.72 \%$ & $1.75 \%$ & $3.97 \%$ & $5.09 \%$ & $5.61 \%$ \\
\hline $\begin{array}{l}\text { Las Vegas, } \\
\text { Nevada }\end{array}$ & $11.16 \%$ & $13.61 \%$ & $14.59 \%$ & $19.18 \%$ & $23.64 \%$ & $25.56 \%$ \\
\hline Average & $3.3 \%$ & $4.2 \%$ & $4.6 \%$ & $7.9 \%$ & $9.8 \%$ & $10.9 \%$ \\
\hline Max & $11.2 \%$ & $13.6 \%$ & $14.6 \%$ & $19.2 \%$ & $23.6 \%$ & $26.3 \%$ \\
\hline Min & $0.3 \%$ & $0.6 \%$ & $0.7 \%$ & $1.5 \%$ & $2.2 \%$ & $2.7 \%$ \\
\hline
\end{tabular}




\section{Supermarket:}

Table C.5. Energy assessments, supermarket, R-410A, present

\begin{tabular}{|l|c|c|c|c|c|c|}
\hline \multicolumn{1}{|c}{$\begin{array}{c}\text { R410A } \\
\text { city }\end{array}$} & \multicolumn{2}{|c|}{ Annual energy saving } & \multicolumn{2}{c|}{ Peak power reduction } \\
\cline { 2 - 7 } & Ewb05 & Ewb07 & Ewb09 & Ewb05 & Ewb07 & Ewb09 \\
\hline $\begin{array}{l}\text { Albuquerque, } \\
\text { New Mexico }\end{array}$ & $13.01 \%$ & $17.21 \%$ & $20.39 \%$ & $17.36 \%$ & $23.23 \%$ & $28.09 \%$ \\
\hline $\begin{array}{l}\text { Los Angeles, } \\
\text { California }\end{array}$ & $3.79 \%$ & $5.59 \%$ & $7.15 \%$ & $4.67 \%$ & $6.88 \%$ & $8.94 \%$ \\
\hline $\begin{array}{l}\text { Atlanta, } \\
\text { Georgia }\end{array}$ & $5.32 \%$ & $7.67 \%$ & $9.79 \%$ & $13.16 \%$ & $18.10 \%$ & $22.53 \%$ \\
\hline $\begin{array}{l}\text { Baltimore, } \\
\text { Maryland }\end{array}$ & $5.71 \%$ & $8.18 \%$ & $10.41 \%$ & $8.00 \%$ & $10.67 \%$ & $13.22 \%$ \\
\hline $\begin{array}{l}\text { Boulder, } \\
\text { Colorado }\end{array}$ & $12.80 \%$ & $16.85 \%$ & $19.84 \%$ & $21.24 \%$ & $27.82 \%$ & $32.99 \%$ \\
\hline $\begin{array}{l}\text { Chicago, } \\
\text { Illinois }\end{array}$ & $5.89 \%$ & $8.41 \%$ & $10.67 \%$ & $11.38 \%$ & $15.77 \%$ & $19.75 \%$ \\
\hline $\begin{array}{l}\text { Duluth, } \\
\text { Minnesota }\end{array}$ & $3.47 \%$ & $5.13 \%$ & $6.58 \%$ & $9.71 \%$ & $13.50 \%$ & $16.09 \%$ \\
\hline $\begin{array}{l}\text { Fairbanks, } \\
\text { Alaska }\end{array}$ & $4.05 \%$ & $5.68 \%$ & $6.92 \%$ & $11.23 \%$ & $15.31 \%$ & $18.80 \%$ \\
\hline $\begin{array}{l}\text { San } \\
\text { Francisco, } \\
\text { California }\end{array}$ & $6.19 \%$ & $8.66 \%$ & $10.75 \%$ & $18.33 \%$ & $24.29 \%$ & $29.15 \%$ \\
\hline $\begin{array}{l}\text { Helena, } \\
\text { Montana }\end{array}$ & $11.94 \%$ & $15.85 \%$ & $18.86 \%$ & $22.28 \%$ & $28.95 \%$ & $34.01 \%$ \\
\hline $\begin{array}{l}\text { Houston, } \\
\text { Texas }\end{array}$ & $5.39 \%$ & $7.81 \%$ & $10.06 \%$ & $8.29 \%$ & $11.30 \%$ & $14.15 \%$ \\
\hline $\begin{array}{l}\text { Miami, } \\
\text { Florida }\end{array}$ & $4.13 \%$ & $6.16 \%$ & $8.06 \%$ & $6.70 \%$ & $9.08 \%$ & $11.35 \%$ \\
\hline $\begin{array}{l}\text { Minneapolis, } \\
\text { Minnesota }\end{array}$ & $5.01 \%$ & $7.25 \%$ & $9.27 \%$ & $6.34 \%$ & $9.16 \%$ & $11.82 \%$ \\
\hline $\begin{array}{l}\text { Phoenix, } \\
\text { Arizona }\end{array}$ & $17.68 \%$ & $23.50 \%$ & $28.25 \%$ & $26.06 \%$ & $33.27 \%$ & $39.51 \%$ \\
\hline $\begin{array}{l}\text { Seattle, } \\
\text { Washington }\end{array}$ & $6.64 \%$ & $9.29 \%$ & $11.56 \%$ & $19.48 \%$ & $25.37 \%$ & $30.30 \%$ \\
\hline $\begin{array}{l}\text { Las Vegas, } \\
\text { Nevada }\end{array}$ & $19.78 \%$ & $25.90 \%$ & $30.63 \%$ & $28.32 \%$ & $34.02 \%$ & $38.93 \%$ \\
\hline Average & $8.2 \%$ & $11.2 \%$ & $13.7 \%$ & $14.5 \%$ & $19.2 \%$ & $23.1 \%$ \\
\hline Max & $19.8 \%$ & $25.9 \%$ & $30.6 \%$ & $28.3 \%$ & $34.0 \%$ & $39.5 \%$ \\
\hline Min & $3.5 \%$ & $5.1 \%$ & $6.6 \%$ & $4.7 \%$ & $6.9 \%$ & $8.9 \%$ \\
\hline
\end{tabular}


Table C.6. Energy assessments, supermarket, R-22, present

\begin{tabular}{|l|c|c|c|c|c|c|}
\hline \multicolumn{1}{|c|}{$\begin{array}{c}\text { R22 } \\
\text { city }\end{array}$} & \multicolumn{2}{|c|}{ Annual energy saving } & \multicolumn{2}{c|}{ Peak power reduction } \\
\cline { 2 - 7 } & Ewb05 & Ewb07 & Ewb09 & Ewb05 & Ewb07 & Ewb09 \\
\hline $\begin{array}{l}\text { Albuquerque, } \\
\text { New Mexico }\end{array}$ & $5.90 \%$ & $7.09 \%$ & $7.34 \%$ & $11.63 \%$ & $14.77 \%$ & $16.68 \%$ \\
\hline $\begin{array}{l}\text { Los Angeles, } \\
\text { California }\end{array}$ & $0.29 \%$ & $0.63 \%$ & $0.77 \%$ & $1.45 \%$ & $2.32 \%$ & $3.02 \%$ \\
\hline $\begin{array}{l}\text { Atlanta, } \\
\text { Georgia }\end{array}$ & $1.85 \%$ & $2.77 \%$ & $3.47 \%$ & $8.90 \%$ & $11.90 \%$ & $14.28 \%$ \\
\hline $\begin{array}{l}\text { Baltimore, } \\
\text { Maryland }\end{array}$ & $2.20 \%$ & $3.22 \%$ & $3.99 \%$ & $3.46 \%$ & $5.11 \%$ & $6.60 \%$ \\
\hline $\begin{array}{l}\text { Boulder, } \\
\text { Colorado }\end{array}$ & $5.47 \%$ & $6.44 \%$ & $6.49 \%$ & $14.71 \%$ & $18.13 \%$ & $19.51 \%$ \\
\hline $\begin{array}{l}\text { Chicago, } \\
\text { Illinois }\end{array}$ & $2.09 \%$ & $3.04 \%$ & $3.72 \%$ & $7.16 \%$ & $9.70 \%$ & $11.75 \%$ \\
\hline $\begin{array}{l}\text { Duluth, } \\
\text { Minnesota }\end{array}$ & $0.17 \%$ & $0.54 \%$ & $0.75 \%$ & $5.27 \%$ & $6.54 \%$ & $7.54 \%$ \\
\hline $\begin{array}{l}\text { Fairbanks, } \\
\text { Alaska }\end{array}$ & $-0.26 \%$ & $-0.22 \%$ & $-0.37 \%$ & $5.67 \%$ & $7.32 \%$ & $8.29 \%$ \\
\hline $\begin{array}{l}\text { San } \\
\text { Francisco, } \\
\text { California }\end{array}$ & $1.32 \%$ & $1.77 \%$ & $1.84 \%$ & $11.62 \%$ & $14.60 \%$ & $16.31 \%$ \\
\hline $\begin{array}{l}\text { Helena, } \\
\text { Montana }\end{array}$ & $4.96 \%$ & $5.94 \%$ & $6.06 \%$ & $14.49 \%$ & $17.63 \%$ & $18.94 \%$ \\
\hline $\begin{array}{l}\text { Houston, } \\
\text { Texas }\end{array}$ & $2.33 \%$ & $3.48 \%$ & $4.44 \%$ & $4.72 \%$ & $6.57 \%$ & $8.23 \%$ \\
\hline $\begin{array}{l}\text { Miami, } \\
\text { Florida }\end{array}$ & $1.39 \%$ & $2.28 \%$ & $3.03 \%$ & $2.72 \%$ & $4.13 \%$ & $5.33 \%$ \\
\hline $\begin{array}{l}\text { Minneapolis, } \\
\text { Minnesota }\end{array}$ & $1.46 \%$ & $2.24 \%$ & $2.80 \%$ & $3.41 \%$ & $5.00 \%$ & $6.42 \%$ \\
\hline $\begin{array}{l}\text { Phoenix, } \\
\text { Arizona }\end{array}$ & $11.71 \%$ & $14.79 \%$ & $16.62 \%$ & $21.81 \%$ & $27.02 \%$ & $30.81 \%$ \\
\hline $\begin{array}{l}\text { Seattle, } \\
\text { Washington }\end{array}$ & $1.76 \%$ & $2.37 \%$ & $2.59 \%$ & $13.57 \%$ & $16.97 \%$ & $19.14 \%$ \\
\hline $\begin{array}{l}\text { Las Vegas, } \\
\text { Nevada }\end{array}$ & $12.73 \%$ & $15.67 \%$ & $17.08 \%$ & $21.96 \%$ & $25.82 \%$ & $28.62 \%$ \\
\hline Average & $3.5 \%$ & $4.5 \%$ & $5.0 \%$ & $9.5 \%$ & $12.1 \%$ & $13.8 \%$ \\
\hline Max & $12.7 \%$ & $15.7 \%$ & $17.1 \%$ & $22.0 \%$ & $27.0 \%$ & $30.8 \%$ \\
\hline Min & $-0.3 \%$ & $-0.2 \%$ & $-0.4 \%$ & $1.5 \%$ & $2.3 \%$ & $3.0 \%$ \\
\hline
\end{tabular}




\section{C.2 POST 1980}

Medium Office:

Table C.7. Energy assessments, medium office, R-22, post-1980

\begin{tabular}{|l|c|c|c|c|c|c|}
\hline \multicolumn{1}{|c|}{$\begin{array}{c}\text { R22 } \\
\text { city }\end{array}$} & \multicolumn{2}{|c|}{ Annual energy saving } & \multicolumn{2}{c|}{ Peak power reduction } \\
\cline { 2 - 7 } & Ewb05 & Ewb07 & Ewb09 & Ewb05 & Ewb07 & Ewb09 \\
\hline $\begin{array}{l}\text { Albuquerque, } \\
\text { New Mexico }\end{array}$ & $4.23 \%$ & $5.09 \%$ & $5.25 \%$ & $12.31 \%$ & $15.43 \%$ & $17.45 \%$ \\
\hline $\begin{array}{l}\text { Los Angeles, } \\
\text { California }\end{array}$ & $-0.61 \%$ & $-0.49 \%$ & $-0.48 \%$ & $0.32 \%$ & $1.35 \%$ & $1.60 \%$ \\
\hline $\begin{array}{l}\text { Atlanta, } \\
\text { Georgia }\end{array}$ & $0.91 \%$ & $1.56 \%$ & $2.04 \%$ & $8.87 \%$ & $11.87 \%$ & $14.24 \%$ \\
\hline $\begin{array}{l}\text { Baltimore, } \\
\text { Maryland }\end{array}$ & $1.00 \%$ & $1.67 \%$ & $2.17 \%$ & $4.35 \%$ & $5.94 \%$ & $7.37 \%$ \\
\hline $\begin{array}{l}\text { Boulder, } \\
\text { Colorado }\end{array}$ & $3.34 \%$ & $3.92 \%$ & $3.90 \%$ & $16.86 \%$ & $20.16 \%$ & $21.41 \%$ \\
\hline $\begin{array}{l}\text { Chicago, } \\
\text { Illinois }\end{array}$ & $1.21 \%$ & $1.89 \%$ & $2.36 \%$ & $2.76 \%$ & $4.06 \%$ & $5.24 \%$ \\
\hline $\begin{array}{l}\text { Duluth, } \\
\text { Minnesota }\end{array}$ & $0.05 \%$ & $0.37 \%$ & $0.55 \%$ & $1.20 \%$ & $1.99 \%$ & $2.63 \%$ \\
\hline $\begin{array}{l}\text { Fairbanks, } \\
\text { Alaska }\end{array}$ & $-0.40 \%$ & $-0.42 \%$ & $-0.62 \%$ & $2.93 \%$ & $3.82 \%$ & $4.21 \%$ \\
\hline $\begin{array}{l}\text { San } \\
\text { Francisco, } \\
\text { California }\end{array}$ & $-0.82 \%$ & $-0.82 \%$ & $-0.96 \%$ & $12.26 \%$ & $16.68 \%$ & $18.22 \%$ \\
\hline $\begin{array}{l}\text { Helena, } \\
\text { Montana }\end{array}$ & $2.32 \%$ & $2.78 \%$ & $2.76 \%$ & $13.81 \%$ & $17.05 \%$ & $18.32 \%$ \\
\hline $\begin{array}{l}\text { Houston, } \\
\text { Texas }\end{array}$ & $1.65 \%$ & $2.60 \%$ & $3.38 \%$ & $4.72 \%$ & $6.67 \%$ & $7.99 \%$ \\
\hline $\begin{array}{l}\text { Miami, } \\
\text { Florida }\end{array}$ & $1.31 \%$ & $2.17 \%$ & $2.90 \%$ & $4.18 \%$ & $6.01 \%$ & $7.63 \%$ \\
\hline $\begin{array}{l}\text { Minneapolis, } \\
\text { Minnesota }\end{array}$ & $0.78 \%$ & $1.34 \%$ & $1.72 \%$ & $4.06 \%$ & $5.83 \%$ & $7.39 \%$ \\
\hline $\begin{array}{l}\text { Phoenix, } \\
\text { Arizona }\end{array}$ & $9.98 \%$ & $12.54 \%$ & $14.03 \%$ & $21.17 \%$ & $26.73 \%$ & $30.77 \%$ \\
\hline $\begin{array}{l}\text { Seattle, } \\
\text { Washington }\end{array}$ & $-0.28 \%$ & $-0.14 \%$ & $-0.18 \%$ & $5.81 \%$ & $7.36 \%$ & $8.40 \%$ \\
\hline $\begin{array}{l}\text { Las Vegas, } \\
\text { Nevada }\end{array}$ & $10.62 \%$ & $13.02 \%$ & $14.14 \%$ & $23.61 \%$ & $27.80 \%$ & $29.80 \%$ \\
\hline Average & $2.2 \%$ & $2.9 \%$ & $3.3 \%$ & $8.7 \%$ & $11.2 \%$ & $12.7 \%$ \\
\hline Max & $10.6 \%$ & $13.0 \%$ & $14.1 \%$ & $23.6 \%$ & $27.8 \%$ & $30.8 \%$ \\
\hline Min & $-0.8 \%$ & $-0.8 \%$ & $-1.0 \%$ & $0.3 \%$ & $1.4 \%$ & $1.6 \%$ \\
\hline
\end{tabular}




\section{Secondary School:}

Table C.8. Energy assessments, secondary school, R-22, post-1980

\begin{tabular}{|l|c|c|c|c|c|c|}
\hline \multicolumn{1}{|c|}{$\begin{array}{c}\text { R22 } \\
\text { city }\end{array}$} & \multicolumn{2}{|c|}{ Annual energy saving } & \multicolumn{2}{c|}{ Peak power reduction } \\
\cline { 2 - 7 } & Ewb05 & Ewb07 & Ewb09 & Ewb05 & Ewb07 & Ewb09 \\
\hline $\begin{array}{l}\text { Albuquerque, } \\
\text { New Mexico }\end{array}$ & $5.64 \%$ & $6.66 \%$ & $6.76 \%$ & $13.47 \%$ & $16.54 \%$ & $17.26 \%$ \\
\hline $\begin{array}{l}\text { Los Angeles, } \\
\text { California }\end{array}$ & $0.36 \%$ & $0.68 \%$ & $0.79 \%$ & $2.39 \%$ & $3.45 \%$ & $4.22 \%$ \\
\hline $\begin{array}{l}\text { Atlanta, } \\
\text { Georgia }\end{array}$ & $1.80 \%$ & $2.65 \%$ & $3.25 \%$ & $7.17 \%$ & $8.81 \%$ & $10.14 \%$ \\
\hline $\begin{array}{l}\text { Baltimore, } \\
\text { Maryland }\end{array}$ & $2.09 \%$ & $3.03 \%$ & $3.69 \%$ & $5.20 \%$ & $7.04 \%$ & $8.23 \%$ \\
\hline $\begin{array}{l}\text { Boulder, } \\
\text { Colorado }\end{array}$ & $5.56 \%$ & $6.50 \%$ & $6.51 \%$ & $14.02 \%$ & $17.45 \%$ & $18.08 \%$ \\
\hline $\begin{array}{l}\text { Chicago, } \\
\text { Illinois }\end{array}$ & $2.01 \%$ & $2.88 \%$ & $3.45 \%$ & $3.74 \%$ & $5.25 \%$ & $6.51 \%$ \\
\hline $\begin{array}{l}\text { Duluth, } \\
\text { Minnesota }\end{array}$ & $1.48 \%$ & $2.14 \%$ & $2.50 \%$ & $1.80 \%$ & $2.69 \%$ & $3.36 \%$ \\
\hline $\begin{array}{l}\text { Fairbanks, } \\
\text { Alaska }\end{array}$ & $1.87 \%$ & $2.20 \%$ & $2.04 \%$ & $6.09 \%$ & $7.34 \%$ & $7.58 \%$ \\
\hline $\begin{array}{l}\text { San } \\
\text { Francisco, } \\
\text { California }\end{array}$ & $1.67 \%$ & $2.16 \%$ & $2.20 \%$ & $8.50 \%$ & $10.84 \%$ & $11.78 \%$ \\
\hline $\begin{array}{l}\text { Helena, } \\
\text { Montana }\end{array}$ & $5.23 \%$ & $6.29 \%$ & $6.50 \%$ & $11.57 \%$ & $14.42 \%$ & $14.98 \%$ \\
\hline $\begin{array}{l}\text { Houston, } \\
\text { Texas }\end{array}$ & $1.73 \%$ & $2.65 \%$ & $3.37 \%$ & $4.72 \%$ & $5.90 \%$ & $6.96 \%$ \\
\hline $\begin{array}{l}\text { Miami, } \\
\text { Florida }\end{array}$ & $0.99 \%$ & $1.73 \%$ & $2.33 \%$ & $3.42 \%$ & $4.37 \%$ & $5.22 \%$ \\
\hline $\begin{array}{l}\text { Minneapolis, } \\
\text { Minnesota }\end{array}$ & $1.61 \%$ & $2.39 \%$ & $2.90 \%$ & $3.78 \%$ & $5.26 \%$ & $6.39 \%$ \\
\hline $\begin{array}{l}\text { Phoenix, } \\
\text { Arizona }\end{array}$ & $10.14 \%$ & $12.64 \%$ & $13.91 \%$ & $18.61 \%$ & $23.28 \%$ & $26.35 \%$ \\
\hline $\begin{array}{l}\text { Seattle, } \\
\text { Washington }\end{array}$ & $1.49 \%$ & $1.95 \%$ & $2.01 \%$ & $4.44 \%$ & $5.73 \%$ & $6.39 \%$ \\
\hline $\begin{array}{l}\text { Las Vegas, } \\
\text { Nevada }\end{array}$ & $11.26 \%$ & $13.73 \%$ & $14.73 \%$ & $19.16 \%$ & $23.62 \%$ & $25.53 \%$ \\
\hline Average & $3.4 \%$ & $4.4 \%$ & $4.8 \%$ & $8.0 \%$ & $10.1 \%$ & $11.2 \%$ \\
\hline Max & $11.3 \%$ & $13.7 \%$ & $14.7 \%$ & $19.2 \%$ & $23.6 \%$ & $26.4 \%$ \\
\hline Min & $0.4 \%$ & $0.7 \%$ & $0.8 \%$ & $1.8 \%$ & $2.7 \%$ & $3.4 \%$ \\
\hline
\end{tabular}




\section{Supermarket:}

Table C.9. Energy assessments, supermarket, R-22, post-1980

\begin{tabular}{|c|c|c|c|c|c|c|}
\hline \multirow{2}{*}{$\begin{array}{l}\text { R22 } \\
\text { city }\end{array}$} & \multicolumn{3}{|c|}{ Annual energy saving } & \multicolumn{3}{|c|}{ Peak power reduction } \\
\hline & Ewb05 & Ewb07 & Ewb09 & Ewb05 & Ewb07 & Ewb09 \\
\hline $\begin{array}{l}\text { Albuquerque, } \\
\text { New Mexico }\end{array}$ & $6.21 \%$ & $7.47 \%$ & $7.76 \%$ & $12.41 \%$ & $15.62 \%$ & $17.52 \%$ \\
\hline $\begin{array}{l}\text { Los Angeles, } \\
\text { California }\end{array}$ & $0.68 \%$ & $1.12 \%$ & $1.33 \%$ & $2.34 \%$ & $3.44 \%$ & $4.29 \%$ \\
\hline $\begin{array}{l}\text { Atlanta, } \\
\text { Georgia }\end{array}$ & $2.12 \%$ & $3.13 \%$ & $3.90 \%$ & $9.06 \%$ & $12.13 \%$ & $14.57 \%$ \\
\hline $\begin{array}{l}\text { Baltimore, } \\
\text { Maryland }\end{array}$ & $2.43 \%$ & $3.52 \%$ & $4.35 \%$ & $7.06 \%$ & $8.88 \%$ & $10.33 \%$ \\
\hline $\begin{array}{l}\text { Boulder, } \\
\text { Colorado }\end{array}$ & $5.93 \%$ & $7.01 \%$ & $7.10 \%$ & $15.02 \%$ & $18.51 \%$ & $20.13 \%$ \\
\hline $\begin{array}{l}\text { Chicago, } \\
\text { Illinois }\end{array}$ & $2.44 \%$ & $3.50 \%$ & $4.27 \%$ & $7.32 \%$ & $9.93 \%$ & $11.97 \%$ \\
\hline $\begin{array}{l}\text { Duluth, } \\
\text { Minnesota }\end{array}$ & $0.76 \%$ & $1.29 \%$ & $1.64 \%$ & $2.29 \%$ & $3.49 \%$ & $4.53 \%$ \\
\hline $\begin{array}{l}\text { Fairbanks, } \\
\text { Alaska }\end{array}$ & $2.08 \%$ & $2.55 \%$ & $2.49 \%$ & $5.71 \%$ & $7.38 \%$ & $8.36 \%$ \\
\hline $\begin{array}{l}\text { San } \\
\text { Francisco, } \\
\text { California }\end{array}$ & $2.43 \%$ & $3.15 \%$ & $3.40 \%$ & $11.69 \%$ & $14.70 \%$ & $16.44 \%$ \\
\hline $\begin{array}{l}\text { Helena, } \\
\text { Montana }\end{array}$ & $5.49 \%$ & $6.59 \%$ & $6.77 \%$ & $13.70 \%$ & $16.72 \%$ & $18.27 \%$ \\
\hline $\begin{array}{l}\text { Houston, } \\
\text { Texas }\end{array}$ & $2.44 \%$ & $3.62 \%$ & $4.61 \%$ & $4.25 \%$ & $6.13 \%$ & $7.81 \%$ \\
\hline $\begin{array}{l}\text { Miami, } \\
\text { Florida }\end{array}$ & $1.49 \%$ & $2.41 \%$ & $3.19 \%$ & $2.65 \%$ & $4.07 \%$ & $5.35 \%$ \\
\hline $\begin{array}{l}\text { Minneapolis, } \\
\text { Minnesota } \\
\end{array}$ & $1.80 \%$ & $2.69 \%$ & $3.36 \%$ & $3.46 \%$ & $5.08 \%$ & $6.52 \%$ \\
\hline $\begin{array}{l}\text { Phoenix, } \\
\text { Arizona }\end{array}$ & $11.67 \%$ & $14.75 \%$ & $16.59 \%$ & $20.94 \%$ & $26.40 \%$ & $30.31 \%$ \\
\hline $\begin{array}{l}\text { Seattle, } \\
\text { Washington }\end{array}$ & $2.30 \%$ & $3.07 \%$ & $3.40 \%$ & $12.27 \%$ & $15.72 \%$ & $17.97 \%$ \\
\hline $\begin{array}{l}\text { Las Vegas, } \\
\text { Nevada }\end{array}$ & $12.57 \%$ & $15.47 \%$ & $16.85 \%$ & $18.44 \%$ & $22.55 \%$ & $25.58 \%$ \\
\hline Average & $3.9 \%$ & $5.1 \%$ & $5.7 \%$ & $9.3 \%$ & $11.9 \%$ & $13.7 \%$ \\
\hline Max & $12.6 \%$ & $15.5 \%$ & $16.8 \%$ & $20.9 \%$ & $26.4 \%$ & $30.3 \%$ \\
\hline Min & $0.7 \%$ & $1.1 \%$ & $1.3 \%$ & $2.3 \%$ & $3.4 \%$ & $4.3 \%$ \\
\hline
\end{tabular}




\section{C.3 PRE-1980}

\section{Secondary School:}

Table C.10. Energy assessments, secondary school, R-22, pre-1980

\begin{tabular}{|c|c|c|c|c|c|c|}
\hline \multirow{2}{*}{$\begin{array}{l}\mathrm{R} 22 \\
\text { city }\end{array}$} & \multicolumn{3}{|c|}{ Annual energy saving } & \multicolumn{3}{|c|}{ Peak power reduction } \\
\hline & Ewb05 & Ewb07 & Ewb09 & Ewb05 & Ewb07 & Ewb09 \\
\hline $\begin{array}{l}\text { Albuquerque, } \\
\text { New Mexico }\end{array}$ & $4.48 \%$ & $5.31 \%$ & $5.37 \%$ & $13.67 \%$ & $16.15 \%$ & $17.04 \%$ \\
\hline $\begin{array}{l}\text { Los Angeles, } \\
\text { California }\end{array}$ & $-0.25 \%$ & $-0.07 \%$ & $-0.03 \%$ & $2.60 \%$ & $3.60 \%$ & $4.27 \%$ \\
\hline $\begin{array}{l}\text { Atlanta, } \\
\text { Georgia }\end{array}$ & $1.56 \%$ & $2.36 \%$ & $2.94 \%$ & $7.39 \%$ & $9.26 \%$ & $10.66 \%$ \\
\hline $\begin{array}{l}\text { Baltimore, } \\
\text { Maryland }\end{array}$ & $1.85 \%$ & $2.74 \%$ & $3.36 \%$ & $5.11 \%$ & $6.65 \%$ & $7.80 \%$ \\
\hline $\begin{array}{l}\text { Boulder, } \\
\text { Colorado }\end{array}$ & $4.09 \%$ & $4.76 \%$ & $4.69 \%$ & $13.29 \%$ & $16.46 \%$ & $17.38 \%$ \\
\hline $\begin{array}{l}\text { Chicago, } \\
\text { Illinois }\end{array}$ & $1.72 \%$ & $2.52 \%$ & $3.06 \%$ & $3.48 \%$ & $4.99 \%$ & $6.25 \%$ \\
\hline $\begin{array}{l}\text { Duluth, } \\
\text { Minnesota }\end{array}$ & $0.76 \%$ & $1.24 \%$ & $1.50 \%$ & $3.66 \%$ & $4.86 \%$ & $5.54 \%$ \\
\hline $\begin{array}{l}\text { Fairbanks, } \\
\text { Alaska }\end{array}$ & $0.38 \%$ & $0.46 \%$ & $0.28 \%$ & $2.48 \%$ & $3.23 \%$ & $3.49 \%$ \\
\hline $\begin{array}{l}\text { San } \\
\text { Francisco, } \\
\text { California }\end{array}$ & $0.03 \%$ & $0.18 \%$ & $0.11 \%$ & $8.94 \%$ & $11.36 \%$ & $12.66 \%$ \\
\hline $\begin{array}{l}\text { Helena, } \\
\text { Montana }\end{array}$ & $3.27 \%$ & $3.93 \%$ & $3.97 \%$ & $11.05 \%$ & $13.59 \%$ & $14.79 \%$ \\
\hline $\begin{array}{l}\text { Houston, } \\
\text { Texas }\end{array}$ & $1.75 \%$ & $2.69 \%$ & $3.44 \%$ & $3.82 \%$ & $5.08 \%$ & $6.23 \%$ \\
\hline $\begin{array}{l}\text { Miami, } \\
\text { Florida }\end{array}$ & $1.07 \%$ & $1.84 \%$ & $2.47 \%$ & $3.95 \%$ & $4.98 \%$ & $5.81 \%$ \\
\hline $\begin{array}{l}\text { Minneapolis, } \\
\text { Minnesota }\end{array}$ & $1.21 \%$ & $1.88 \%$ & $2.32 \%$ & $3.90 \%$ & $5.46 \%$ & $6.68 \%$ \\
\hline $\begin{array}{l}\text { Phoenix, } \\
\text { Arizona }\end{array}$ & $9.44 \%$ & $11.84 \%$ & $13.11 \%$ & $19.39 \%$ & $24.24 \%$ & $27.52 \%$ \\
\hline $\begin{array}{l}\text { Seattle, } \\
\text { Washington }\end{array}$ & $0.37 \%$ & $0.63 \%$ & $0.62 \%$ & $5.97 \%$ & $7.71 \%$ & $8.72 \%$ \\
\hline $\begin{array}{l}\text { Las Vegas, } \\
\text { Nevada }\end{array}$ & $9.94 \%$ & $12.15 \%$ & $13.05 \%$ & $19.23 \%$ & $23.99 \%$ & $26.25 \%$ \\
\hline Average & $2.6 \%$ & $3.4 \%$ & $3.8 \%$ & $8.0 \%$ & $10.1 \%$ & $11.3 \%$ \\
\hline Max & $9.9 \%$ & $12.1 \%$ & $13.1 \%$ & $19.4 \%$ & $24.2 \%$ & $27.5 \%$ \\
\hline Min & $-0.2 \%$ & $-0.1 \%$ & $0.0 \%$ & $2.5 \%$ & $3.2 \%$ & $3.5 \%$ \\
\hline
\end{tabular}




\section{Supermarket:}

Table C.11. Energy assessments, supermarket, R-22, pre-1980

\begin{tabular}{|l|c|c|c|c|c|c|}
\hline \multicolumn{1}{|c|}{$\begin{array}{c}\text { R22 } \\
\text { city }\end{array}$} & \multicolumn{2}{|c|}{ Annual energy saving } & \multicolumn{2}{c|}{ Peak power reduction } \\
\cline { 2 - 7 } & Ewb05 & Ewb07 & Ewb09 & Ewb05 & Ewb07 & Ewb09 \\
\hline $\begin{array}{l}\text { Albuquerque, } \\
\text { New Mexico }\end{array}$ & $6.31 \%$ & $7.60 \%$ & $7.92 \%$ & $12.60 \%$ & $15.95 \%$ & $17.96 \%$ \\
\hline $\begin{array}{l}\text { Los Angeles, } \\
\text { California }\end{array}$ & $0.66 \%$ & $1.09 \%$ & $1.29 \%$ & $2.34 \%$ & $3.43 \%$ & $4.28 \%$ \\
\hline $\begin{array}{l}\text { Atlanta, } \\
\text { Georgia }\end{array}$ & $2.19 \%$ & $3.21 \%$ & $4.00 \%$ & $9.05 \%$ & $12.12 \%$ & $14.58 \%$ \\
\hline $\begin{array}{l}\text { Baltimore, } \\
\text { Maryland }\end{array}$ & $2.52 \%$ & $3.64 \%$ & $4.49 \%$ & $6.46 \%$ & $8.42 \%$ & $9.88 \%$ \\
\hline $\begin{array}{l}\text { Boulder, } \\
\text { Colorado }\end{array}$ & $5.96 \%$ & $7.04 \%$ & $7.13 \%$ & $14.39 \%$ & $17.80 \%$ & $19.51 \%$ \\
\hline $\begin{array}{l}\text { Chicago, } \\
\text { Illinois }\end{array}$ & $2.49 \%$ & $3.55 \%$ & $4.33 \%$ & $7.33 \%$ & $9.94 \%$ & $12.01 \%$ \\
\hline $\begin{array}{l}\text { Duluth, } \\
\text { Minnesota }\end{array}$ & $1.74 \%$ & $2.55 \%$ & $3.10 \%$ & $2.29 \%$ & $3.50 \%$ & $4.54 \%$ \\
\hline $\begin{array}{l}\text { Fairbanks, } \\
\text { Alaska }\end{array}$ & $2.12 \%$ & $2.59 \%$ & $2.53 \%$ & $5.72 \%$ & $7.39 \%$ & $8.37 \%$ \\
\hline $\begin{array}{l}\text { San } \\
\text { Francisco, } \\
\text { California }\end{array}$ & $2.32 \%$ & $3.03 \%$ & $3.26 \%$ & $11.66 \%$ & $14.66 \%$ & $16.39 \%$ \\
\hline $\begin{array}{l}\text { Helena, } \\
\text { Montana }\end{array}$ & $5.54 \%$ & $6.66 \%$ & $6.83 \%$ & $13.10 \%$ & $16.15 \%$ & $17.72 \%$ \\
\hline $\begin{array}{l}\text { Houston, } \\
\text { Texas }\end{array}$ & $2.52 \%$ & $3.73 \%$ & $4.73 \%$ & $4.23 \%$ & $6.10 \%$ & $7.78 \%$ \\
\hline $\begin{array}{l}\text { Miami, } \\
\text { Florida }\end{array}$ & $1.54 \%$ & $2.47 \%$ & $3.26 \%$ & $3.79 \%$ & $5.01 \%$ & $6.10 \%$ \\
\hline $\begin{array}{l}\text { Minneapolis, } \\
\text { Minnesota }\end{array}$ & $2.07 \%$ & $3.04 \%$ & $3.77 \%$ & $3.46 \%$ & $5.08 \%$ & $6.52 \%$ \\
\hline $\begin{array}{l}\text { Phoenix, } \\
\text { Arizona }\end{array}$ & $11.74 \%$ & $14.81 \%$ & $16.64 \%$ & $20.81 \%$ & $26.29 \%$ & $30.22 \%$ \\
\hline $\begin{array}{l}\text { Seattle, } \\
\text { Washington }\end{array}$ & $2.40 \%$ & $3.19 \%$ & $3.54 \%$ & $12.31 \%$ & $15.77 \%$ & $18.04 \%$ \\
\hline $\begin{array}{l}\text { Las Vegas, } \\
\text { Nevada }\end{array}$ & $12.58 \%$ & $15.48 \%$ & $16.85 \%$ & $15.07 \%$ & $19.37 \%$ & $22.54 \%$ \\
\hline Average & $4.0 \%$ & $5.2 \%$ & $5.9 \%$ & $9.0 \%$ & $11.7 \%$ & $13.5 \%$ \\
\hline Max & $12.6 \%$ & $15.5 \%$ & $16.9 \%$ & $20.8 \%$ & $26.3 \%$ & $30.2 \%$ \\
\hline Min & $0.7 \%$ & $1.1 \%$ & $1.3 \%$ & $2.3 \%$ & $3.4 \%$ & $4.3 \%$ \\
\hline
\end{tabular}




\section{APPENDIX D. TABLES OF ECONOMICS}

This section presents the detailed economics analysis. Table D.1 indicates the water and electricity rates for six selected cities. Table D.2 shows nominal total cooling capacities according to each building type and climate zone, and the total capacity is the sum of individual equipment capacities in the building. And the building situations about floor area, zones, etc. can be seen in Tables D.3 through D.8. The economics are given in dollars of annual saving per cooling ton of nominal total capacity; they are related to three building types, two refrigerants, three levels of COPs ( $\mathrm{COP}=3.0, \mathrm{COP}=4.0$ and $\mathrm{COP}=5.0)$, and two levels of wet bulb efficiency $(E w b=0.7$ and $E w b=0.9)$. COP $=3.0$ represents the lowest equipment efficiency available on current market; $\mathrm{COP}=5.0$ represents the highest efficiency; and $\mathrm{COP}=4.0$ represents the medium efficiency. In addition, we compared the saving dollars with respect to two water usage strategies, one is to supply water at all ambient temperatures, and the other is to only supply water at the ambient temperatures above $90^{\circ} \mathrm{F}$. This is to identify which city has potential to use less water but achieve bigger cost saving.

Table D.1. Water and electricity rates for selected cities

\begin{tabular}{|l|c|c|c|c|c|c|}
\hline \multicolumn{1}{|c|}{ Cost (cents) } & $\begin{array}{c}\text { Albuquerque, } \\
\text { New Mexico }\end{array}$ & $\begin{array}{c}\text { Atlanta, } \\
\text { Georgia }\end{array}$ & $\begin{array}{c}\text { Houston, } \\
\text { Texas }\end{array}$ & $\begin{array}{c}\text { Minneapolis, } \\
\text { Minnesota }\end{array}$ & $\begin{array}{c}\text { Phoenix, } \\
\text { Arizona }\end{array}$ & $\begin{array}{c}\text { Seattle, } \\
\text { Washington }\end{array}$ \\
\hline Water $/ \mathrm{m}^{3}$ & 49.80 & 27.68 & 94.06 & 107.44 & 123.98 & 158.59 \\
\hline Electricity $/ \mathrm{kwh}$ & 8.65 & 8.89 & 9.45 & 8.13 & 10.11 & 7.26 \\
\hline
\end{tabular}

Table D.2. Nominal total cooling capacities (baseline equipment tonnages sum)

\begin{tabular}{|l|c|c|c|}
\hline \multicolumn{1}{|c|}{ City/building } & Medium office & Secondary school & Supermarket \\
\hline Albuquerque, New Mexico & 91 & 214 & 108 \\
\hline Atlanta, Georgia & 102 & 263 & 109 \\
\hline Houston, Texas & 110 & 265 & 110 \\
\hline Minneapolis, Minnesota & 103 & 263 & 136 \\
\hline Phoenix, Arizona & 112 & 266 & 104 \\
\hline Seattle, Washington & 84 & 207 & 82 \\
\hline
\end{tabular}


Table D.3. Annual dollars saving per cooling ton, $\mathrm{COP}=3.0$, Ewb $=0.7$

\begin{tabular}{|c|c|c|c|c|c|c|}
\hline \multirow{3}{*}{$\begin{array}{c}\text { Equipment COP }=\mathbf{3 . 0}(\mathbf{w} / 0 \text { indoor fan }) \\
\text { City } \\
\end{array}$} & \multicolumn{6}{|c|}{ Net Dollars saved with water supply at all ambient temperatures (dry bulb) } \\
\hline & \multicolumn{2}{|c|}{ Medium office } & \multicolumn{2}{|c|}{ Secondary school } & \multicolumn{2}{|c|}{ Supermarket } \\
\hline & R410A equipment & R22 equipment & R410A equipment & R22 equipment & R410A equipment & R22 equipment \\
\hline Albuquerque, New Mexico & 8.36 & 1.78 & 8.65 & 2.35 & 3.48 & 1.07 \\
\hline Atlanta, Georgia & 4.98 & 0.90 & 5.20 & 1.36 & 3.17 & 0.97 \\
\hline Houston, Texas & 6.61 & 0.69 & 6.70 & 0.24 & 5.41 & 1.13 \\
\hline Minneapolis, Minnesota & 1.24 & -0.97 & 1.17 & -0.48 & 0.53 & -0.22 \\
\hline Phoenix, Arizona & 24.72 & 9.18 & 26.10 & 9.37 & 21.04 & 9.43 \\
\hline Seattle, Washington & -0.40 & -1.83 & -0.01 & -0.59 & 0.02 & -0.29 \\
\hline
\end{tabular}

Net Dollars saved with water supply at temperatures above $90^{\circ} \mathrm{F}$ (dry bulb)

Medium office Secondary school

Supermarket

\begin{tabular}{|c|c|c|c|c|c|}
\hline R410A equipment & R22 equipment & R410A equipment & R22 equipment & R410A equipment & R22 equipment \\
\hline 2.04 & 1.02 & 2.35 & 1.15 & 1.06 & 0.52 \\
\hline 0.46 & 0.26 & 0.45 & 0.22 & 0.44 & 0.25 \\
\hline 2.23 & 1.07 & 1.86 & 0.62 & 2.07 & 0.92 \\
\hline 0.11 & 0.04 & 0.08 & 0.02 & 0.07 & 0.03 \\
\hline 19.59 & 10.44 & 19.90 & 9.62 & 17.93 & 9.42 \\
\hline 0.03 & 0.00 & 0.00 & 0.00 & 0.02 & 0.00 \\
\hline
\end{tabular}

Saving Difference Between the Two Controls (Ambient DB Temperatures above $90^{\circ} \mathrm{F}$-All Ambient Temperatures)

Medium office

Secondary school

Supermarket

\begin{tabular}{|c|c|c|c|c|c|}
\hline R410A equipment & R22 equipment & R410A equipment & R22 equipment & R410A equipment & R22 equipment \\
\hline-6.32 & -0.76 & -6.29 & -1.20 & -2.42 & -0.55 \\
\hline-4.52 & -0.63 & -4.75 & -1.14 & -2.72 & -0.72 \\
\hline-4.38 & 0.38 & -4.83 & 0.38 & -3.34 & -0.22 \\
\hline-1.13 & 1.01 & -1.09 & 0.50 & -0.45 & 0.24 \\
\hline-5.13 & 1.26 & -6.20 & 0.25 & -3.11 & -0.01 \\
\hline 0.42 & 1.84 & 0.01 & 0.59 & 0.00 & 0.29 \\
\hline
\end{tabular}


Table D.4. Annual dollars saving per cooling ton, $\mathrm{COP}=4.0$, Ewb $=0.7$

\begin{tabular}{|c|c|c|c|c|c|c|}
\hline \multirow{3}{*}{$\begin{array}{c}\text { Equipment COP }=4.0 \text { (w/o indoor fan) } \\
\text { City }\end{array}$} & \multicolumn{6}{|c|}{ Net Dollars saved with water supply at all ambient temperatures (dry bulb) } \\
\hline & \multicolumn{2}{|c|}{ Medium office } & \multicolumn{2}{|c|}{ Secondary school } & \multicolumn{2}{|c|}{ Supermarket } \\
\hline & R410A equipment & R22 equipment & R410A equipment & R22 equipment & R410A equipment & R22 equipment \\
\hline Albuquerque, New Mexico & 5.80 & 0.85 & 6.03 & 1.30 & 2.44 & 0.62 \\
\hline Atlanta, Georgia & 3.55 & 0.48 & 3.73 & 0.85 & 2.27 & 0.62 \\
\hline Houston, Texas & 4.10 & -0.37 & 4.08 & -0.78 & 3.42 & 0.19 \\
\hline Minneapolis, Minnesota & 0.53 & -1.14 & 0.58 & -0.67 & 0.25 & -0.31 \\
\hline Phoenix, Arizona & 15.76 & 4.03 & 16.40 & 3.78 & 13.53 & 4.78 \\
\hline Seattle, Washington & -0.73 & -1.82 & -0.19 & -0.63 & -0.08 & -0.31 \\
\hline
\end{tabular}

Net Dollars saved with water supply at temperatures above $90 \mathrm{~F}$ (dry bulb)

Medium office Secondary school

Supermarket

\begin{tabular}{|c|c|c|c|c|c|}
\hline R410A equipment & R22 equipment & R410A equipment & R22 equipment & R410A equipment & R22 equipment \\
\hline 1.46 & 0.69 & 1.67 & 0.77 & 0.75 & 0.35 \\
\hline 0.34 & 0.19 & 0.33 & 0.16 & 0.32 & 0.17 \\
\hline 1.50 & 0.62 & 1.19 & 0.26 & 1.37 & 0.50 \\
\hline 0.07 & 0.02 & 0.05 & 0.00 & 0.05 & 0.01 \\
\hline 13.00 & 6.10 & 12.83 & 5.09 & 11.72 & 5.31 \\
\hline 0.01 & 0.00 & 0.00 & 0.00 & 0.01 & -0.01 \\
\hline
\end{tabular}

Saving Difference Between the Two Controls (Ambient DB Temperatures above $90 \mathrm{~F}$ - All Ambient Temperatures)

Medium office

Secondary school

Supermarket

\begin{tabular}{|c|c|c|c|c|c|}
\hline R410A equipment & R22 equipment & R410A equipment & R22 equipment & R410A equipment & R22 equipment \\
\hline-4.35 & -0.16 & -4.36 & -0.53 & -1.68 & -0.27 \\
\hline-3.21 & -0.29 & -3.41 & -0.69 & -1.95 & -0.45 \\
\hline-2.60 & 0.99 & -2.89 & 1.04 & -2.05 & 0.31 \\
\hline-0.46 & 1.16 & -0.53 & 0.67 & -0.21 & 0.32 \\
\hline-2.76 & 2.07 & -3.56 & 1.31 & -1.81 & 0.54 \\
\hline 0.74 & 1.82 & 0.19 & 0.63 & 0.09 & 0.31 \\
\hline
\end{tabular}


Table D.5. Annual dollars saving per cooling ton, $\mathrm{COP}=5.0$, Ewb $=0.7$

Equipment COP $=5.0$ (w/o indoor fan) $\quad$ Net Dollars saved with water supply at all ambient temperatures (dry bulb)

Medium office Secondary school

Supermarket

\begin{tabular}{|l|c|c|c|c|c|c|}
\hline \multicolumn{1}{|c|}{ City } & R410A equipment & R22 equipment & R410A equipment & R22 equipment & R410A equipment & R22 equipment \\
\hline Albuquerque, New Mexico & 4.27 & 0.30 & 4.47 & 0.67 & 1.81 & 0.36 \\
\hline Atlanta, Georgia & 2.69 & 0.23 & 2.85 & 0.54 & 1.74 \\
\hline Houston, Texas & 2.60 & -1.00 & 2.51 & -1.39 & 2.22 \\
\hline Minneapolis, Minnesota & 0.11 & -1.24 & 0.22 & -0.79 & -0.37 \\
\hline Phoenix, Arizona & 10.37 & 0.94 & 10.57 & 0.42 & -0.09 & -0.36 \\
\hline Seattle, Washington & -0.93 & -1.82 & -0.29 & -0.65 & -0.14 & -1.98 \\
\hline
\end{tabular}

Net Dollars saved with water supply at temperatures above $90 \mathrm{~F}$ (dry bulb)

Medium office Secondary school

\begin{tabular}{|c|c|c|c|c|c|}
\multicolumn{2}{c}{ Medium office } & \multicolumn{2}{c|}{ Secondary school } & R22 equipment \\
\hline R410A equipment & R22 equipment & R410A equipment & R22 equipment & R410A equipment & 0.25 \\
\hline 1.11 & 0.49 & 1.26 & 0.54 & 0.57 & 0.13 \\
\hline 0.26 & 0.14 & 0.25 & 0.12 & 0.25 & 0.25 \\
\hline 1.06 & 0.36 & 0.79 & 0.04 & 0.95 & 0.00 \\
\hline 0.05 & 0.01 & 0.03 & -0.01 & 0.03 & 2.85 \\
\hline 9.04 & 3.49 & 8.59 & 2.36 & 8.00 & -0.01 \\
\hline 0.00 & -0.01 & 0.00 & 0.00 & 0.00 & \\
\hline
\end{tabular}

Saving Difference Between the Two Controls (Ambient DB Temperatures above $90 \mathrm{~F}$ - All Ambient Temperatures)

Medium office

Secondary school Supermarket

\begin{tabular}{|c|c|c|c|c|c|}
\hline R410A equipment & R22 equipment & R410A equipment & R22 equipment & R410A equipment & R22 equipment \\
\hline-3.16 & 0.19 & -3.20 & -0.13 & -1.24 & -0.11 \\
\hline-2.42 & -0.09 & -2.60 & -0.43 & -1.49 & -0.28 \\
\hline-1.53 & 1.36 & -1.72 & 1.44 & -1.27 & 0.62 \\
\hline-0.06 & 1.24 & -0.19 & 0.77 & -0.06 & 0.36 \\
\hline-1.34 & 2.55 & -1.98 & 1.94 & -1.02 & 0.86 \\
\hline 0.94 & 1.81 & 0.29 & 0.65 & 0.14 & 0.32 \\
\hline
\end{tabular}


Table D.6. Annual dollars saving per cooling ton, $\mathrm{COP}=3.0, \mathrm{Ewb}=0.9$

Equipment $\mathrm{COP}=3.0$ (w/o indoor fan)

Net Dollars saved with water supply at all ambient temperatures (dry bulb)

\begin{tabular}{|l|c|c|c|c|c|c|}
\multicolumn{4}{|c}{ Medium office } & \multicolumn{4}{c}{ Secondary school } \\
\hline City & R410A equipment & R22 equipment & R410A equipment & R22 equipment & R410A equipment & R22 equipment \\
\hline Albuquerque, New Mexico & 9.71 & 1.35 & 9.99 & 1.88 & 4.06 & 0.93 \\
\hline Atlanta, Georgia & 6.41 & 1.20 & 6.62 & 1.63 & 4.04 & 1.20 \\
\hline Houston, Texas & 8.60 & 0.96 & 8.71 & 0.29 & 6.99 & 1.42 \\
\hline Minneapolis, Minnesota & 1.59 & -1.24 & 1.48 & -0.67 & 0.67 & -0.29 \\
\hline Phoenix, Arizona & 28.72 & 8.45 & 30.40 & 7.97 & 24.67 & 9.18 \\
\hline Seattle, Washington & -0.53 & -2.35 & -0.04 & -0.80 & 0.02 & -0.39 \\
\hline
\end{tabular}

Net Dollars saved with water supply at temperatures above $90 \mathrm{~F}$ (dry bulb)

Medium office Secondary school

\begin{tabular}{|c|c|c|c|c|c|}
\multicolumn{2}{c}{ Medium office } & \multicolumn{2}{c|}{ Secondary school } & R22 equipment \\
\hline R410A equipment & R22 equipment & R410A equipment & R22 equipment & R410A equipment & 0.52 \\
\hline 2.38 & 1.03 & 2.75 & 1.14 & 1.23 & 0.29 \\
\hline 0.58 & 0.31 & 0.56 & 0.26 & 0.55 & 1.09 \\
\hline 2.80 & 1.28 & 2.36 & 0.72 & 2.61 & 0.03 \\
\hline 0.14 & 0.05 & 0.10 & 0.01 & 0.09 & 9.67 \\
\hline 23.02 & 10.86 & 23.40 & 9.35 & 21.11 & 0.00 \\
\hline 0.03 & 0.00 & 0.00 & 0.00 & 0.03 & \\
\hline
\end{tabular}

Saving Difference Between the Two Controls (Ambient DB Temperatures above $90 \mathrm{~F}$ - All Ambient Temperatures)

\begin{tabular}{|c|c|c|c|c|c|}
\multicolumn{2}{c}{ Medium office } & \multicolumn{2}{c|}{ Supermarket } \\
\hline R410A equipment & R22 equipment & R410A equipment & R22 equipment & R410A equipment & R22 equipment \\
\hline-7.33 & -0.32 & -7.25 & -0.75 & -2.82 & -0.41 \\
\hline-5.83 & -0.89 & -6.06 & -1.37 & -3.49 & -0.91 \\
\hline-5.80 & 0.32 & -6.35 & 0.43 & -4.38 & -0.33 \\
\hline-1.46 & 1.29 & -1.38 & 0.69 & -0.58 & 0.32 \\
\hline-5.70 & 2.41 & -6.99 & 1.38 & -3.56 & 0.49 \\
\hline 0.56 & 2.35 & 0.04 & 0.80 & 0.01 & 0.39 \\
\hline
\end{tabular}


Table D.7. Annual dollars saving per cooling ton, $\mathrm{COP}=4.0$, Ewb $=0.9$

\begin{tabular}{|c|c|c|c|c|c|c|}
\hline \multirow{3}{*}{$\begin{array}{c}\text { Equipment COP }=4.0 \text { (w/o indoor fan) } \\
\text { City }\end{array}$} & \multicolumn{6}{|c|}{ Net Dollars saved with water supply at all ambient temperatures (dry bulb) } \\
\hline & \multicolumn{2}{|c|}{ Medium Office } & \multicolumn{2}{|c|}{ Secondary School } & \multicolumn{2}{|c|}{ Supermarket } \\
\hline & R410A equipment & R22 equipment & R410A equipment & R22 equipment & R410A equipment & R22 equipment \\
\hline Albuquerque, New Mexico & 6.69 & 0.39 & 6.92 & 0.82 & 2.82 & 0.47 \\
\hline Atlanta, Georgia & 4.56 & 0.65 & 4.75 & 1.00 & 2.90 & 0.77 \\
\hline Houston, Texas & 5.35 & -0.41 & 5.33 & -1.02 & 4.43 & 0.22 \\
\hline Minneapolis, Minnesota & 0.69 & -1.46 & 0.73 & -0.90 & 0.32 & -0.40 \\
\hline Phoenix, Arizona & 18.00 & 2.70 & 18.75 & 1.82 & 15.64 & 3.95 \\
\hline Seattle, Washington & -0.95 & -2.34 & -0.26 & -0.84 & -0.11 & -0.42 \\
\hline
\end{tabular}

Net Dollars saved with water supply at temperatures above $90 \mathrm{~F}$ (dry bulb)

\begin{tabular}{l|l|l} 
Medium office & Secondary school & Supermarket
\end{tabular}

\begin{tabular}{|c|c|c|c|c|c|}
\hline R410A equipment & R22 equipment & R410A equipment & R22 equipment & R410A equipment & R22 equipment \\
\hline 1.69 & 0.67 & 1.94 & 0.73 & 0.87 & 0.34 \\
\hline 0.42 & 0.22 & 0.41 & 0.18 & 0.40 & 0.21 \\
\hline 1.88 & 0.73 & 1.51 & 0.28 & 1.73 & 0.58 \\
\hline 0.09 & 0.02 & 0.06 & -0.01 & 0.06 & 0.01 \\
\hline 15.12 & 5.94 & 14.89 & 4.28 & 13.65 & 5.01 \\
\hline 0.01 & -0.01 & 0.00 & 0.00 & 0.01 & -0.01 \\
\hline
\end{tabular}

Saving Difference Between the Two Controls (Ambient DB Temperatures above $90 \mathrm{~F}$ - All Ambient Temperatures)

Medium office

Secondary school

Supermarket

\begin{tabular}{|c|c|c|c|c|c|}
\hline R410A equipment & R22 equipment & R410A equipment & R22 equipment & R410A equipment & R22 equipment \\
\hline-4.99 & 0.28 & -4.98 & -0.09 & -1.95 & -0.13 \\
\hline-4.15 & -0.43 & -4.35 & -0.82 & -2.50 & -0.56 \\
\hline-3.47 & 1.14 & -3.82 & 1.30 & -2.70 & 0.36 \\
\hline-0.60 & 1.48 & -0.67 & 0.89 & -0.27 & 0.41 \\
\hline-2.88 & 3.25 & -3.86 & 2.47 & -2.00 & 1.06 \\
\hline 0.97 & 2.33 & 0.26 & 0.84 & 0.12 & 0.41 \\
\hline
\end{tabular}


Table D.8. Annual dollars saving per cooling ton, $\mathrm{COP}=5.0$, Ewb $=0.9$

\begin{tabular}{|c|c|c|c|c|c|c|}
\hline \multirow{3}{*}{$\begin{array}{c}\text { Equipment COP }=5.0 \text { (w/o indoor fan) } \\
\text { City }\end{array}$} & \multicolumn{6}{|c|}{ Net Dollars saved with water supply at all ambient temperatures (dry bulb) } \\
\hline & \multicolumn{2}{|c|}{ Medium office } & \multicolumn{2}{|c|}{ Secondary school } & \multicolumn{2}{|c|}{ Supermarket } \\
\hline & R410A equipment & R22 equipment & R410A equipment & R22 equipment & R410A equipment & R22 equipment \\
\hline Albuquerque, New Mexico & 4.87 & -0.18 & 5.08 & 0.18 & 2.08 & 0.20 \\
\hline Atlanta, Georgia & 3.46 & 0.33 & 3.63 & 0.63 & 2.22 & 0.51 \\
\hline Houston, Texas & 3.41 & -1.23 & 3.30 & -1.81 & 2.89 & -0.49 \\
\hline Minneapolis, Minnesota & 0.14 & -1.59 & 0.27 & -1.04 & 0.11 & -0.47 \\
\hline Phoenix, Arizona & 11.57 & -0.76 & 11.76 & -1.88 & 10.23 & 0.82 \\
\hline Seattle, Washington & -1.21 & -2.33 & -0.39 & -0.86 & -0.19 & -0.44 \\
\hline
\end{tabular}

Net Dollars saved with water supply at temperatures above $90 \mathrm{~F}$ (dry bulb)

Medium office Secondary school Supermarket

\begin{tabular}{|c|c|c|c|c|c|}
\hline R410A equipment & R22 equipment & R410A equipment & R22 equipment & R410A equipment & R22 equipment \\
\hline 1.28 & 0.46 & 1.46 & 0.49 & 0.66 & 0.23 \\
\hline 0.33 & 0.17 & 0.31 & 0.13 & 0.31 & 0.16 \\
\hline 1.33 & 0.41 & 1.00 & 0.01 & 1.20 & 0.27 \\
\hline 0.06 & 0.00 & 0.03 & -0.02 & 0.04 & 0.00 \\
\hline 10.38 & 2.99 & 9.78 & 1.24 & 9.17 & 2.22 \\
\hline 0.00 & -0.02 & 0.00 & 0.00 & 0.00 & -0.02 \\
\hline
\end{tabular}

Saving Difference Between the Two Controls (Ambient DB Temperatures above $90 \mathrm{~F}$ - All Ambient Temperatures)

Medium office

Secondary school

Supermarket

\begin{tabular}{|c|c|c|c|c|c|}
\hline R410A equipment & R22 equipment & R410A equipment & R22 equipment & R410A equipment & R22 equipment \\
\hline-3.59 & 0.64 & -3.62 & 0.31 & -1.43 & 0.03 \\
\hline-3.13 & -0.16 & -3.32 & -0.49 & -1.91 & -0.35 \\
\hline-2.08 & 1.64 & -2.30 & 1.81 & -1.69 & 0.77 \\
\hline-0.08 & 1.59 & -0.24 & 1.02 & -0.08 & 0.47 \\
\hline-1.20 & 3.75 & -1.98 & 3.12 & -1.06 & 1.41 \\
\hline 1.21 & 2.31 & 0.39 & 0.86 & 0.19 & 0.42 \\
\hline
\end{tabular}

